\title{
Steric enforcement of cis-epoxide formation in the radical C-O-coupling reaction by which $(S)$-2-hydroxypropylphosphonate epoxidase (HppE) produces Fosfomycin
}

Shengbin Zhou, ${ }^{*}$ Juan Pan, Katherine M. Davis, ${ }^{\dagger}$ Irene Schaperdoth, Bo Wang, Amie K. Boal, Carsten Krebs, * J. Martin Bollinger, Jr.*

Department of Chemistry and Department of Biochemistry \& Molecular Biology, The Pennsylvania State University, University Park, PA 16802, United States

*Corresponding authors: szz59@psu.edu, ckrebs@psu.edu,jmb21@psu.edu

†Present address: Department of Chemistry, Emory University, Atlanta, GA 30322, United States

1. General Methods and Background 2

2. Mixed stereochemistry in the $\mathrm{C}-\mathrm{O}$-coupling (cyclization) step of the HppE reaction. ...............3

3. Structure-guided mutagenesis to alter cyclization stereochemistry. .........................................

4. Use of halogen substitution to distinguish between polar and radicaloid $\mathrm{C}-\mathrm{O}$-coupling

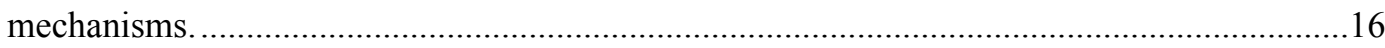

5. Antimicrobial potencies of the (halogenated) cis- and trans-epoxide products........................33

6. The synthesis and characterization of the substrate and product standards. ...............................36

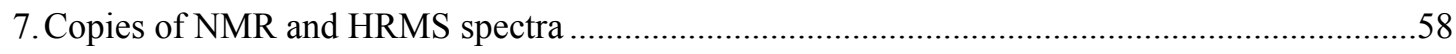

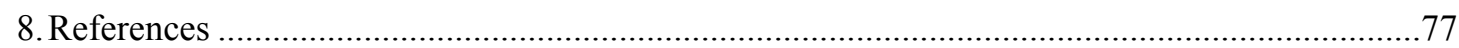




\section{General Methods and Background}

All chemicals and reagents were obtained from commercial suppliers (Sigma-Adrich, VWR, Alfa Aesar) and used without further purification. Silica gel chromatography was carried out using resin (230-400 mesh, grade 60) obtained from Sorbent Technologies (Norcross, GA). ${ }^{1} \mathrm{H},{ }^{31} \mathrm{P},{ }^{19} \mathrm{~F}$ and ${ }^{13} \mathrm{C}$ NMR spectra were recorded on Bruker 360, 400 and $500 \mathrm{MHz}$ spectrometers in the Department of Chemistry at The Pennsylvania State University (PSU). Data for ${ }^{1} \mathrm{H}$ NMR are reported as follows: chemical shifts ( $\delta$ ppm), multiplicity $(\mathrm{s}=$ singlet, $\mathrm{d}=$ doublet, $\mathrm{t}=$ triplet, $\mathrm{q}=$ quartet, $\mathrm{m}=$ multiplet, $\mathrm{dd}=$ doublet of doublets, $\mathrm{td}$ $=$ triplet of doublets, $\mathrm{ddd}=$ doublet of doublet of doublets), coupling constant $(\mathrm{Hz})$, and integrated area (relative to that of solvent, $\mathrm{CDCl}_{3}$ or $\mathrm{D}_{2} \mathrm{O}$, unless otherwise noted). High-resolution mass spectra were obtained at the PSU Mass Spectral Facility. Over-expression and preparation of recombinant HppE and variants were carried out as previously described. ${ }^{1}$

Scheme S1. Two possibilities for the identity, and the mechanism of formation, of the proR $\mathrm{C} 1-\mathrm{H}^{\bullet}-$ abstracting intermediate in the HppE reaction.
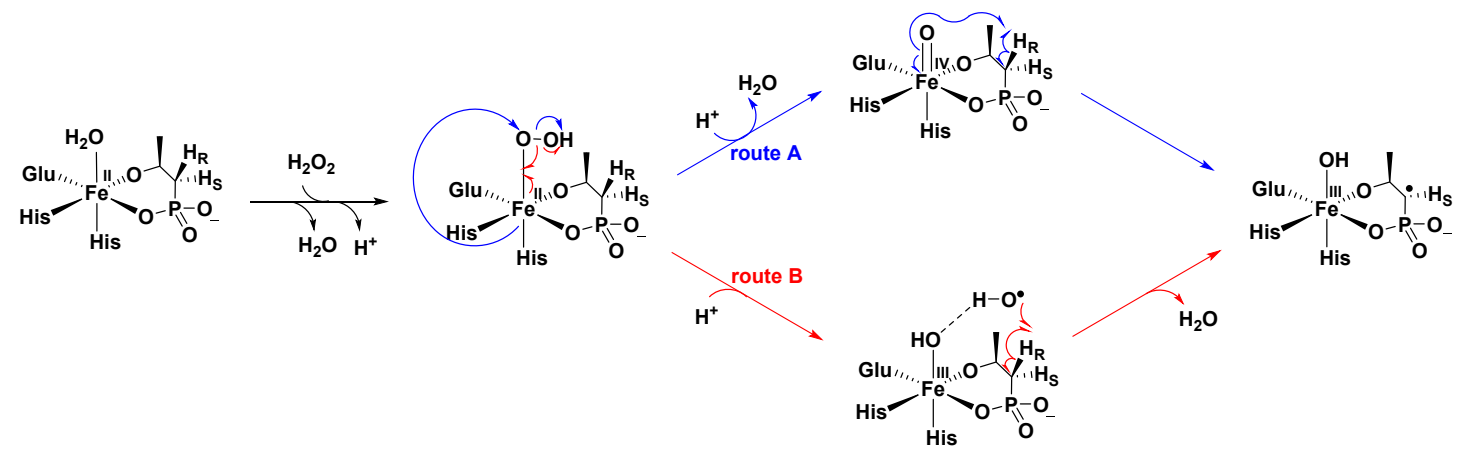

Scheme S2. Distinct oxidation reactions catalyzed by HppE upon its native substrate, $(S)-2$-HPP $(\boldsymbol{A})$, and stereo- and structural isomers thereof $(\boldsymbol{B}-\boldsymbol{D})$.

A<smiles>C[C@H](O)C[Po](=O)(=O)O</smiles>

(S)-2-HPP

C<smiles>CCC(O)[P+]([O])([O])O</smiles>

(S)-1-HPP

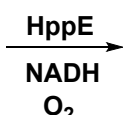

$\mathrm{O}_{2}$<smiles>C[C@@H]1O[C@H]1[P+](=O)O</smiles>

cis-Fos
B

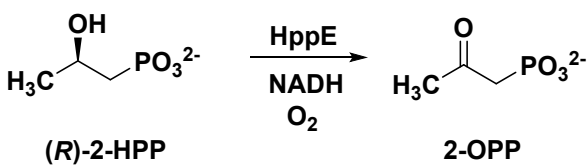

(R)-2-HPP (R)-1-HPP

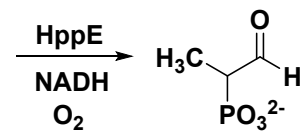<smiles>[R6][Pb](O)([Na])C(O)CC</smiles>

D

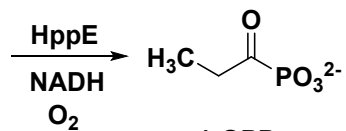

1-OPP

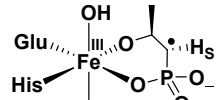

2-OPP 


\section{Mixed stereochemistry in the $\mathrm{C}-\mathrm{O}$-coupling (cyclization) step of the $\mathrm{HppE}$ reaction.}

2.1 Synthesis of rac-trans-Fos (3).

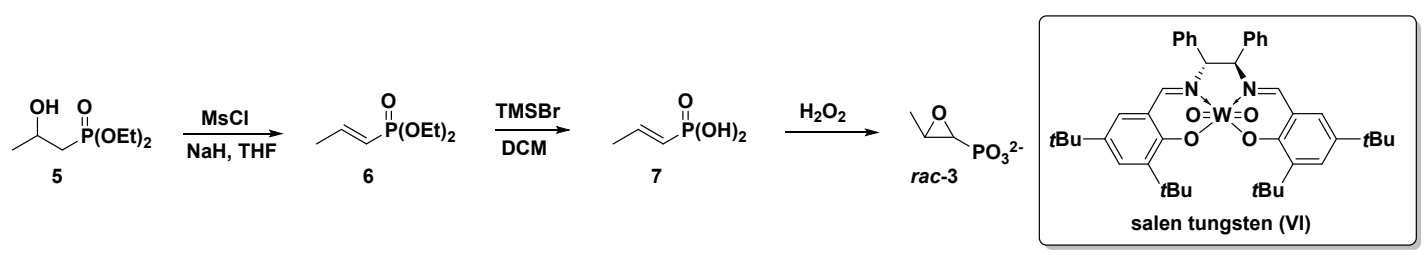

Diethyl (E)-prop-1-en-1-ylphosphonate (6). To a solution of $5(1 \mathrm{~g}, 5.10 \mathrm{mmol})$ in THF $(20 \mathrm{~mL})$ was added $\mathrm{MsCl}(700 \mathrm{mg}, 6.12 \mathrm{mmol})$ and $\mathrm{NaH}(2.4 \mathrm{~g}, 50.97 \mathrm{mmol})$. The reaction was stirred at room temperature (rt) for $5 \mathrm{~h}$ and quenched by addition of water $(80 \mathrm{~mL})$ followed by extraction with ethyl acetate $(50 \mathrm{~mL} \times 3)$. The combined organic layer was concentrated and purified by chromatography [dichloromethane $(\mathrm{DCM}) / \mathrm{methanol}=40 / 1$ ] to afford $6(0.8 \mathrm{~g}, 88 \%) .{ }^{1} \mathrm{H}$ NMR $\left(500 \mathrm{MHz}, \mathrm{CDCl}_{3}\right) \delta 6.84$ $-6.69(\mathrm{~m}, 1 \mathrm{H}), 5.73-5.59(\mathrm{~m}, 1 \mathrm{H}), 4.10-4.02(\mathrm{~m}, 4 \mathrm{H}), 1.91(\mathrm{dt}, J=6.6,2.2 \mathrm{~Hz}, 3 \mathrm{H}), 1.31(\mathrm{t}, J=7.0$ $\mathrm{Hz}, 6 \mathrm{H}) .{ }^{31} \mathrm{P} \mathrm{NMR}\left(202 \mathrm{MHz}, \mathrm{CDCl}_{3}\right) \delta 18.43$.

(E)-prop-1-en-1-ylphosphonate (7). Following the published procedure, ${ }^{1} 7$ was obtained as a white solid $(0.5 \mathrm{~g}, 90 \%)$ from $6(0.8 \mathrm{~g}) .{ }^{1} \mathrm{H}$ NMR $\left(500 \mathrm{MHz}, \mathrm{D}_{2} \mathrm{O}\right) \delta 6.46-6.35(\mathrm{~m}, 1 \mathrm{H}), 5.78-5.69(\mathrm{~m}, 1 \mathrm{H})$, $1.79(\mathrm{dt}, J=6.5,2.0 \mathrm{~Hz}, 3 \mathrm{H}) .{ }^{13} \mathrm{C}$ NMR $\left(126 \mathrm{MHz}, \mathrm{D}_{2} \mathrm{O}\right) \delta 142.67(\mathrm{~d}, J=4.3 \mathrm{~Hz}), 123.56(\mathrm{~d}, J=177.6$ Hz), $19.08(\mathrm{~d}, J=22.6 \mathrm{~Hz}) .{ }^{31} \mathrm{P}$ NMR $\left(202 \mathrm{MHz}, \mathrm{D}_{2} \mathrm{O}\right) \delta 13.31$.

rac-trans-(3-methyloxiran-2-yl)phosphonate (3). Trans-1-propenylphosphonate (250 mg, $2 \mathrm{mmol}$ ) dissolved in $\mathrm{CH}_{2} \mathrm{Cl}_{2}(50 \mathrm{~mL})$ was added to racemic $\alpha$-phenylethylamine ( $250 \mu \mathrm{L}, 2 \mathrm{mmol}$ ), as described previously. ${ }^{2}$ The salen tungsten (VI) catalyst $(0.1 \mathrm{mmol})$ was subsequently added to the mixture. Following addition of $\mathrm{H}_{2} \mathrm{O}_{2}(1.05 \mathrm{~mL}, 10 \mathrm{mmol}, 30 \%$ aqueous $)$, the reaction mixture was stirred at $\mathrm{rt}$ for $24 \mathrm{~h}$. The organic layer was removed after the addition of water to dissolve the epoxide, and the aqueous layer was dried to give the product (200 mg, 71\%). ${ }^{1} \mathrm{H}$ NMR $\left(500 \mathrm{MHz}, \mathrm{D}_{2} \mathrm{O}\right) \delta 3.23-3.18(\mathrm{~m}, 1 \mathrm{H})$, $2.70(\mathrm{dd}, J=24.6,3.1 \mathrm{~Hz}, 1 \mathrm{H}), 1.32(\mathrm{~d}, J=5.3 \mathrm{~Hz}, 3 \mathrm{H}) .{ }^{13} \mathrm{C} \mathrm{NMR}\left(126 \mathrm{MHz}, \mathrm{D}_{2} \mathrm{O}\right) \delta 54.80(\mathrm{~d}, J=182.9$ Hz), 54.28, 16.94. ${ }^{31} \mathrm{P}$ NMR (202 MHz, $100 \mathrm{mM} \mathrm{NaOD}$ in $\mathrm{D}_{2} \mathrm{O}$ ) $\delta 10.49$. 


\subsection{Re-examination of the HppE reaction stereochemistry.}

(S)-2-HPP (1) was synthesized as previously described; the ${ }^{1} \mathrm{H}$, and ${ }^{13} \mathrm{C}$ NMR spectra of $\mathbf{1}$ were consistent with those reported in the literature. ${ }^{1,3}$ To a $25 \mathrm{~mL}$ solution of $20 \mathrm{mM}$ Tris- $\mathrm{HCl}$ buffer ( $\mathrm{pH} 7.5$ ) were added, in an anoxic chamber, $\mathrm{Fe}^{\mathrm{II}}\left[\right.$ from $\left.\mathrm{Fe}\left(\mathrm{NH}_{4}\right)_{2}\left(\mathrm{SO}_{4}\right)_{2}\right](0.8 \mathrm{mM}$ final concentration), $\mathrm{HppE}(1 \mathrm{mM}$ final concentration), (S)-2-HPP (10 mM final concentration), and sodium $L$-ascorbate (20 mM final concentration). $\mathrm{H}_{2} \mathrm{O}_{2}$ (10 mM final concentration) was then added dropwise to the solution at $4{ }^{\circ} \mathrm{C}$, and the reaction was allowed to proceed for an additional $10 \mathrm{~min}$. The $\mathrm{pH}$ of the solution was then adjusted to between 3 and 4 using $6 \mathrm{M} \mathrm{HCl}$, and the sample was centrifuged to remove the precipitated protein. The supernatant was diluted with $200 \mathrm{~mL}$ of water, and this solution was loaded onto a DEAE anion exchange column (15 mL, Bio-Rad). The column was washed with water $(200 \mathrm{~mL})$, and the bound material was then eluted with $30 \mathrm{~mL}$ of $100 \mathrm{mM} \mathrm{NH}_{4} \mathrm{HCO}_{3}$. The eluant was then lyophilized to yield 2 and 3. The conversion $(\sim 100 \%)$ and cis:trans product ratio (95/5) were obtained by ${ }^{1} \mathrm{H}$ NMR analysis (Figure S1). For both $\mathbf{2}$ and $\mathbf{3}$, the spectroscopic data were found to match those reported in the literature. ${ }^{4}$

(1R,2S)-1,2-epoxypropylphosphonate (2). ${ }^{1} \mathrm{H}$ NMR $\left(500 \mathrm{MHz}, \mathrm{D}_{2} \mathrm{O}\right) \delta 3.30(\mathrm{~m}, 1 \mathrm{H}), 2.85$ (dd, $J=19.4$, $5.1 \mathrm{~Hz}, 1 \mathrm{H}), 1.48(\mathrm{~d}, J=5.6 \mathrm{~Hz}, 3 \mathrm{H}) .{ }^{13} \mathrm{C} \mathrm{NMR}\left(75 \mathrm{MHz}, \mathrm{D}_{2} \mathrm{O}\right) \delta 56.43(J=175.7 \mathrm{~Hz}), 54.81,13.89$. ${ }^{31} \mathrm{P}$ NMR (202 MHz, $100 \mathrm{mM} \mathrm{NaOD}$ in $\left.\mathrm{D}_{2} \mathrm{O}\right) \delta 9.95(\mathrm{dd}, J=18.7,5.3 \mathrm{~Hz})$. The coupling of $5.1 \mathrm{~Hz}$ between the vicinal epoxide protons $(\delta 2.85$ and $3.30 \mathrm{ppm})$ indicates a cis configuration. ${ }^{5}$

(1S,2S)-1,2-epoxypropylphosphonate (3). ${ }^{1} \mathrm{H}$ NMR $\left(500 \mathrm{MHz}, \mathrm{D}_{2} \mathrm{O}\right) \delta 3.21-3.18(\mathrm{~m}, 1 \mathrm{H}), 2.64(\mathrm{dd}$, $J=22.2,2.7 \mathrm{~Hz}, 1 \mathrm{H}), 1.36(\mathrm{dd}, J=5.2,1.5 \mathrm{~Hz}, 1 \mathrm{H}) .{ }^{31} \mathrm{P} \mathrm{NMR}\left(202 \mathrm{MHz}, 100 \mathrm{mM} \mathrm{NaOD}\right.$ in $\left.\mathrm{D}_{2} \mathrm{O}\right) \delta$ $10.45(\mathrm{dd}, J=21.7,5.1 \mathrm{~Hz})$. The coupling of $2.7 \mathrm{~Hz}$ between the vicinal epoxide protons indicates a trans configuration. , 6-7 $^{-1}$ 


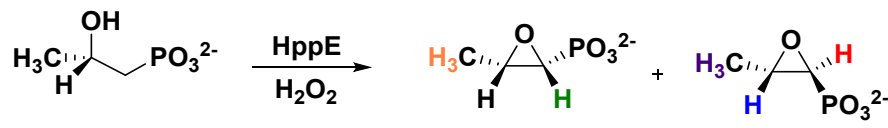

(S)-1

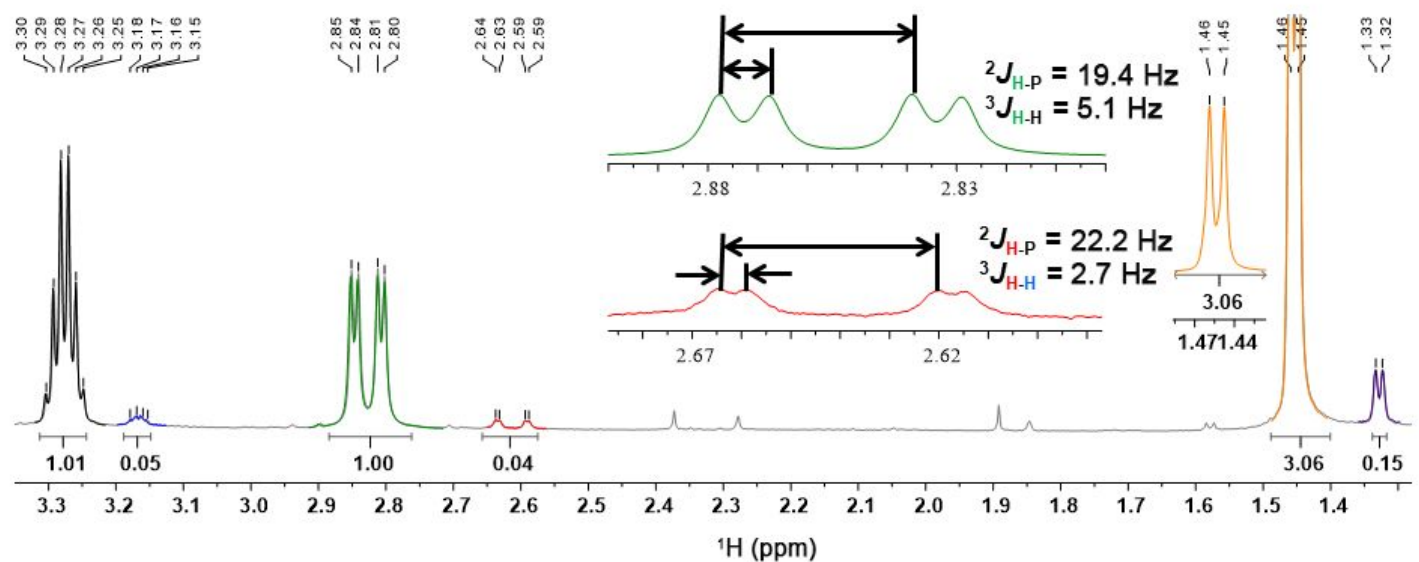

Figure S1. ${ }^{1} \mathrm{H}$ NMR spectrum of products isolated from the HppE reaction.

2.3 Synthesis of 1-d-2S-HPP diastereomers (1d and 1e). For details, see Sec 6.1.

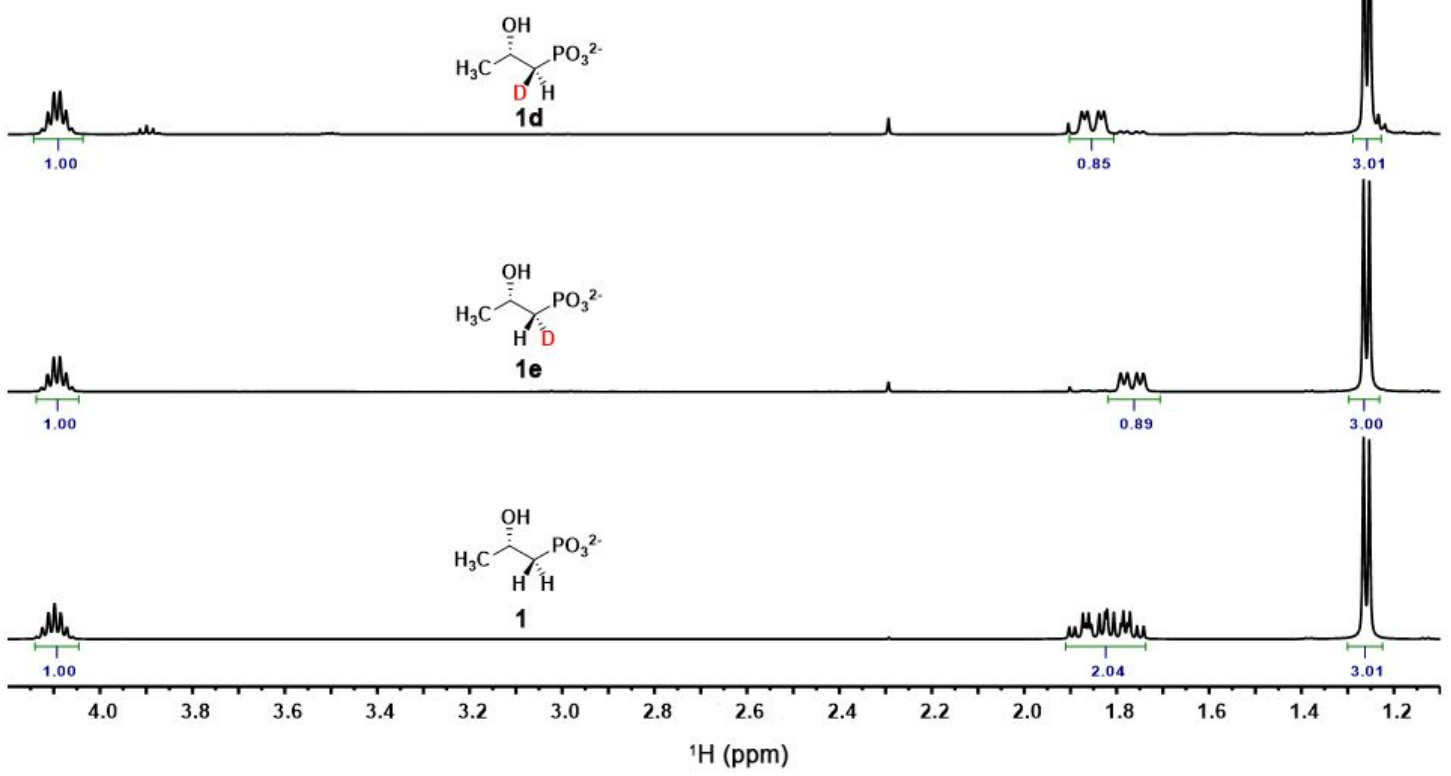

Figure S2. Comparison of the ${ }^{1} \mathrm{H}$ NMR spectra of the two 1-d-2S-HPP diastereomers (1d and 1e) and unlabeled (S)-2-HPP (1).

\subsection{Reaction of 1-d-2S-HPP diastereomers with HрpE.}


Reactions were carried out in $2 \mathrm{~mL}$ tubes in a total volume of $0.50 \mathrm{~mL}$. They contained (final concentrations after addition of $\left.\mathrm{H}_{2} \mathrm{O}_{2}\right) 20 \mathrm{mM}$ Tris- $\mathrm{HCl}$ buffer $(\mathrm{pH} 7.5), 0.16 \mathrm{mM} \mathrm{Fe}$ [from $\left.\mathrm{Fe}\left(\mathrm{NH}_{4}\right)_{2}\left(\mathrm{SO}_{4}\right)_{2}\right], 0.2 \mathrm{mM} \mathrm{HppE}, 5 \mathrm{mM}(S)$-2-HPP or one of its isotopologs, and $4 \mathrm{mM}$ sodium $L$ ascorbate. These components were mixed in an anoxic chamber, and $\mathrm{H}_{2} \mathrm{O}_{2}$ (1 equiv. relative to substrate) was added slowly at rt. Reactions were allowed to proceed for an additional $10 \mathrm{~min}$ (after the addition of $\mathrm{H}_{2} \mathrm{O}_{2}$ was complete) before being quenched by addition of $0.10 \mathrm{~mL}$ of quench solution $\mathbf{A}(600 \mathrm{mM}$ $\mathrm{NaOD}, 3 \mathrm{mM}$ sodium propylphosphonate in $\mathrm{D}_{2} \mathrm{O}$ ). The reaction mixtures were transferred to NMR tubes and subjected to ${ }^{31} \mathrm{P}$ NMR analysis. Each reaction was performed in triplicate. The cis:trans ratios were calculated by integration of the relevant peaks.

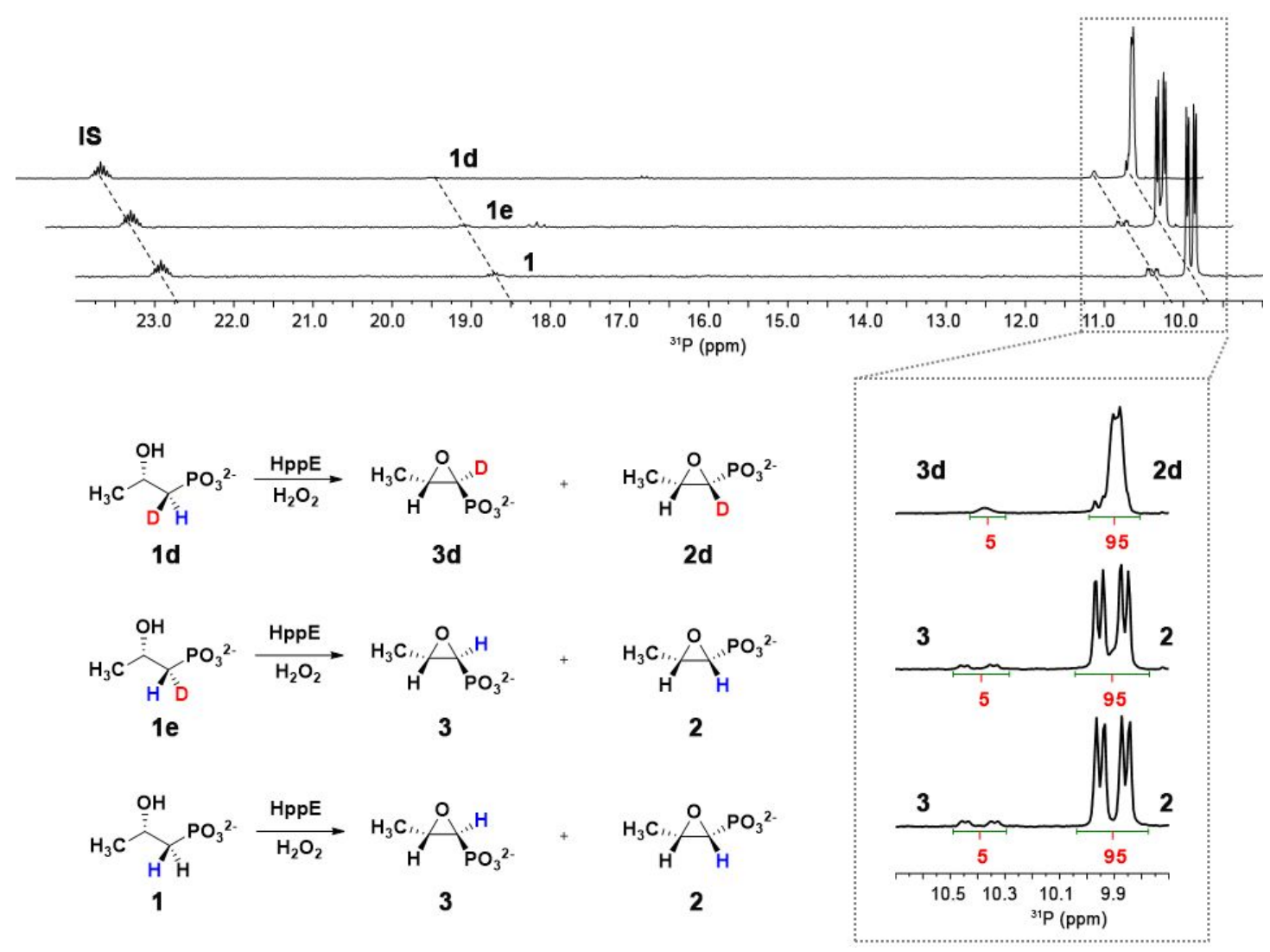

Figure S3. ${ }^{31} \mathrm{P}-\mathrm{NMR}$ spectra of reactions of HppE with $1 S$ - $d$-2S-HPP (1d) $(\boldsymbol{B}$, top line $), 1 R-d-2 S$-HPP (1e) $(\boldsymbol{B}$, middle line) and $(S)$-2-HPP (1) (B, bottom line). The multiplet at $\sim 23.0 \mathrm{ppm}$ is from the sodium propylphosphonate internal standard. The doublet of doublets $\left({ }^{2} J_{\mathrm{P}-\mathrm{H}}=\sim 21,{ }^{3} J_{\mathrm{P}-\mathrm{H}}=\sim 5 \mathrm{~Hz}\right)$ and doublet $\left({ }^{3} J_{\mathrm{P}-\mathrm{H}}=\sim 5 \mathrm{~Hz}\right)$ signals at $\sim 10.4$ are from trans-Fos $(3)$ and trans-1-d-Fos (3d), respectively. The doublet of doublets $\left({ }^{2} J_{\mathrm{P}-\mathrm{H}}=\sim 19,{ }^{3} J_{\mathrm{P}-\mathrm{H}}=\sim 5 \mathrm{~Hz}\right)$ and doublet $\left({ }^{3} J_{\mathrm{P}-\mathrm{H}}=\sim 5 \mathrm{~Hz}\right)$ signals at $\sim 9.9$ are from cis-Fos (2) and $c i s-1-d$-Fos (2d), respectively. The Scheme above the figure summarizes the reaction outcomes $(\boldsymbol{A})$. 


\section{Structure-guided mutagenesis to alter cyclization stereochemistry.}

\subsection{DNA constructs for overexpression of F182A, L193F, L120F, L193A, L193F/L144F HppE}

variants. The plasmid encoding HppE from Streptomyces wedmorensis was used as a template for inserting single-codon substitutions into the various constructs, except in the case of the construct for the L193F/L144F double variant, which was produced using the plasmid encoding the L193F single variant as the template. The final constructs were verified by DNA sequencing at the PSU Molecular Core Facility. The various $\mathrm{L} \rightarrow \mathrm{A}, \mathrm{L} \rightarrow \mathrm{F}$, and $\mathrm{F} \rightarrow \mathrm{A}$ substitutions were generated following previously published methods ${ }^{8}$ using the primers listed in the table below:

\begin{tabular}{|c|l|l|}
\hline \multirow{2}{*}{ Primer name } & & \multicolumn{1}{c|}{ sequence } \\
\hline \multirow{2}{*}{ L120F } & Forward & 5'-TTTGTGGTGGACGTGCTGACGG-3' \\
\cline { 2 - 3 } & Reverse & 5'-GGGGACGAGCGAAGGCGC-3' \\
\hline \multirow{2}{*}{ F182A } & Forward & 5'-GCGACGGCGGCCAAGGGCACG-3' \\
\cline { 2 - 3 } & Reverse & 5'-GGCGTGCGGCACGTGCTC-3' \\
\hline \multirow{2}{*}{ L193F } & Forward & 5'-TTTATCGCCGTCAACTTCTGAAAGC-3' \\
\cline { 2 - 3 } & Reverse & 5'-CTTCGCGGAACCCGTGCCC-3' \\
\hline \multirow{2}{*}{ L144F } & Forward & 5'-TTTTTCGTGCTCGAGGGCGAG-3' \\
\cline { 2 - 3 } & Reverse & 5'-GAACTCGTTGCCGGCGTGG-3' \\
\hline
\end{tabular}

\subsection{Standard curves for Fos and (S)-2-HPP.}

Table S1. Standard curves for Fos and (S)-2-HPP used in ${ }^{31} \mathrm{P}$ NMR analysis. Representative NMR spectra are shown below each standard curve. All data points represent the average of duplicate trials. The standard curves plot product/substrate concentration in $\mathrm{mM}$ ( $y$-axis) against the ratio of the integrated NMR peak areas from the product/substrate and the internal standard ( $x$-axis). Each assay contained 0.60 $\mathrm{mL}$ of $0.1 \sim 4.8 \mathrm{mM}$ substrate or product, $0.5 \mathrm{mM} \mathrm{H}_{3} \mathrm{PO}_{4}$ as the internal standard, and $100 \mathrm{mM} \mathrm{NaOD}$ in $\mathrm{D}_{2} \mathrm{O}$. 


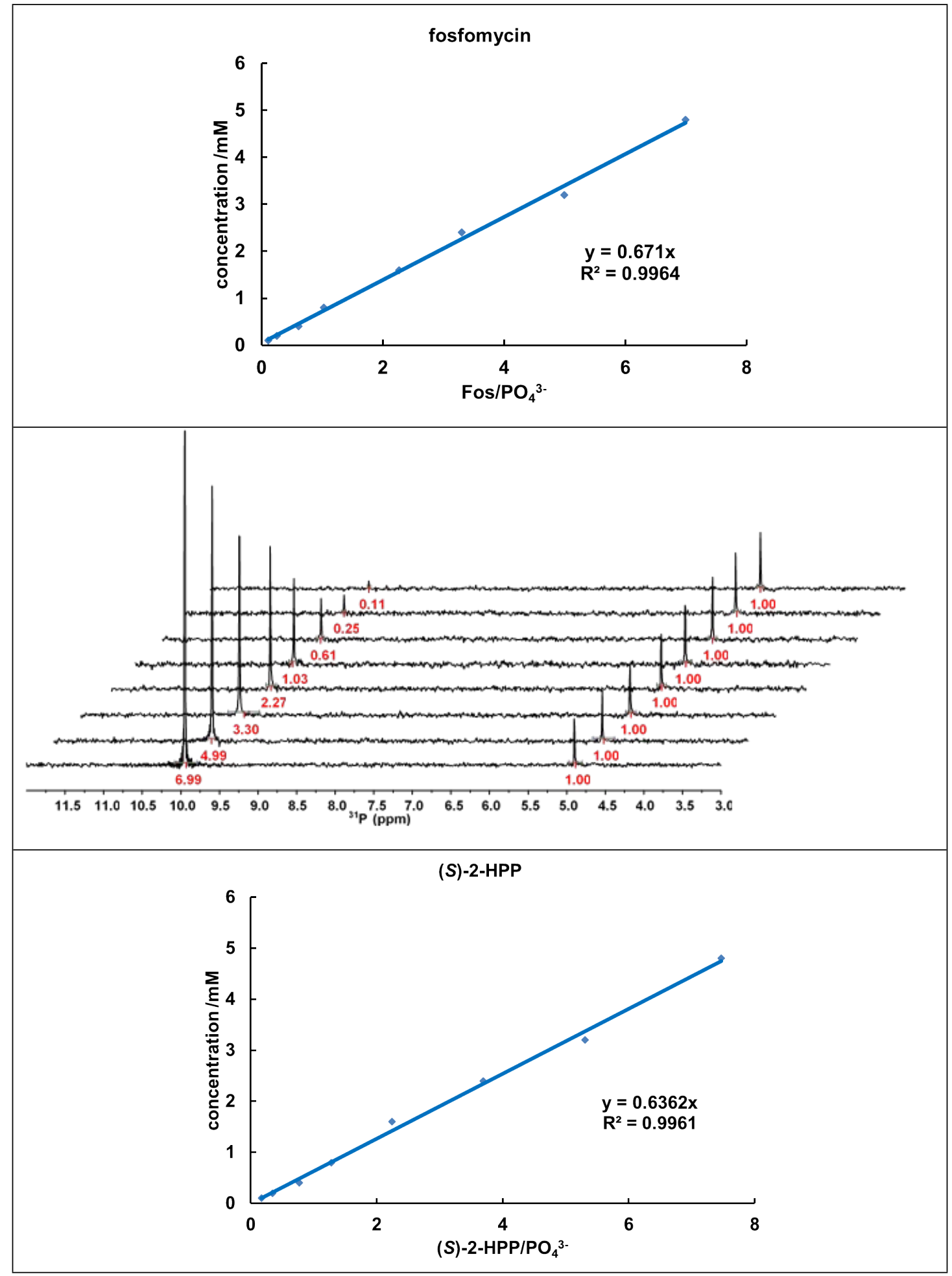




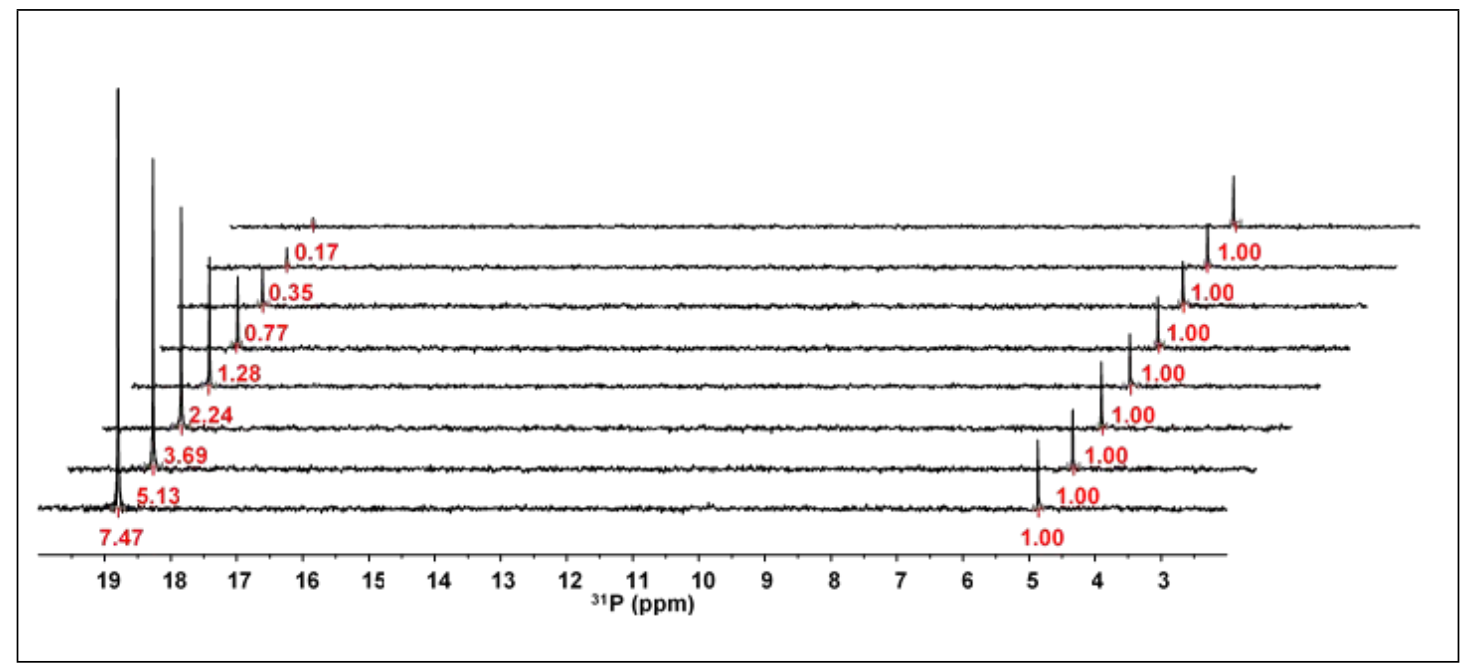

\subsection{Determination of total turnover number (TTN)}

Assays were carried out in a total volume of $0.5 \mathrm{~mL}$ in $2 \mathrm{~mL}$ tubes. They contained $20 \mathrm{mM}$ Tris- $\mathrm{HCl}$ buffer ( $\mathrm{pH} 7.5), \mathrm{Fe}^{\mathrm{II}}$ [from $\mathrm{Fe}\left(\mathrm{NH}_{4}\right)_{2}\left(\mathrm{SO}_{4}\right)_{2}, 0.08 \mathrm{mM}$ final concentration], HppE (1.25 equiv. relative to $\left.\mathrm{Fe}^{\mathrm{II}}\right),(S)$-2-HPP (5 mM final concentration), and sodium L-ascorbate (25 equiv. relative to $\left.\mathrm{Fe}^{\mathrm{II}}\right) . \mathrm{H}_{2} \mathrm{O}_{2}(1$ equiv. relative to the substrate) was added slowly into the solution at $\mathrm{rt}$ in an anoxic chamber. The reaction was then allowed to proceed for additional $10 \mathrm{~min}$ before being quenched by the addition of $0.10 \mathrm{~mL}$ of solution $\mathbf{B}\left(600 \mathrm{mM} \mathrm{NaOD}, 3 \mathrm{mM} \mathrm{H}_{3} \mathrm{PO}_{4}\right.$ in $\left.\mathrm{D}_{2} \mathrm{O}\right)$. The mixtures were subsequently transferred to NMR tubes and subjected to ${ }^{31}$ PCPD NMR analysis. Each reaction was performed in triplicate. TTNs were calculated relative to the $\mathrm{Fe}^{\mathrm{II}}$ concentration.

TTN

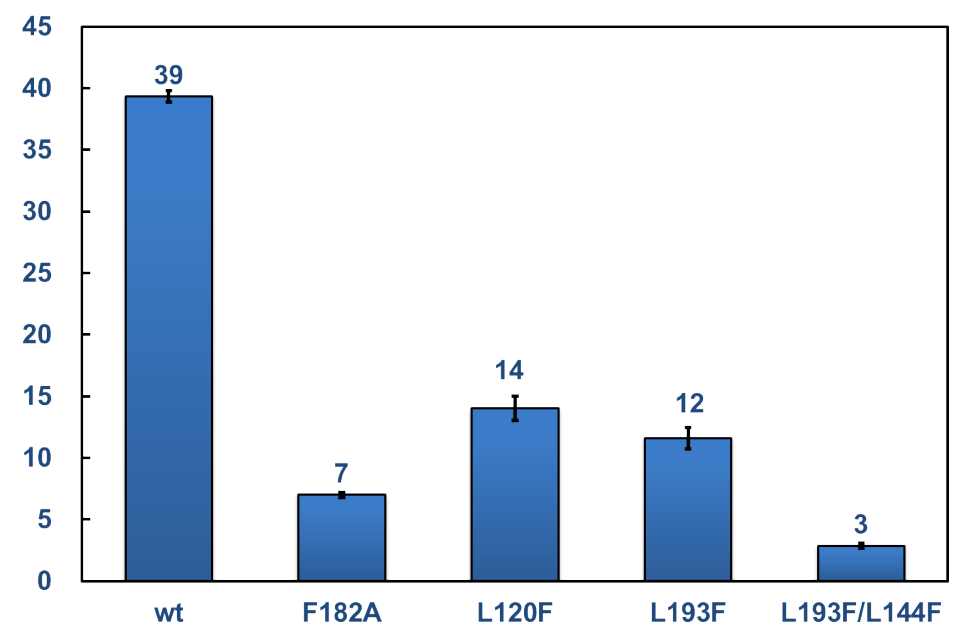

Figure S4. TTNs of reactions of $(S)$-2-HPP with HppE or variants. 


\subsection{Fos $/ \mathrm{H}_{2} \mathrm{O}_{2}$ reaction stoichiometries for wild type HppE and variants.}

Assays $(0.50 \mathrm{~mL})$ were carried out in $2 \mathrm{~mL}$ tubes and contained $20 \mathrm{mM}$ Tris-HCl buffer $(\mathrm{pH} 7.5), \mathrm{Fe}^{\mathrm{II}}$ [from $\mathrm{Fe}\left(\mathrm{NH}_{4}\right)_{2}\left(\mathrm{SO}_{4}\right)_{2}, 0.08 / 0.4 / 0.3 \mathrm{mM}$ final concentration for HppE/F182A/L193F, respectively], enzyme (1.25 equiv. relative to $\left.\mathrm{Fe}^{\mathrm{II}}\right),(S)$-2-HPP (5 mM final concentration), and sodium L-ascorbate (25 equiv. relative to $\mathrm{Fe}^{\mathrm{II}}$ ). Varying quantities of $\mathrm{H}_{2} \mathrm{O}_{2}$ were added slowly into the solution at $\mathrm{rt}$ in an anoxic chamber. The specific reaction conditions for each experiment are given in the Figure legends below. The reaction was allowed to proceed for $10 \mathrm{~min}$ after addition of $\mathrm{H}_{2} \mathrm{O}_{2}$ before being quenched by addition of $0.10 \mathrm{~mL}$ of solution $\mathbf{B}\left(600 \mathrm{mM} \mathrm{NaOD}, 3 \mathrm{mM} \mathrm{H}_{3} \mathrm{PO}_{4}\right.$ in $\left.\mathrm{D}_{2} \mathrm{O}\right)$. The samples were subsequently transferred to NMR tubes and subjected to ${ }^{31}$ PCPD NMR analysis. Each reaction was performed in triplicate.

A

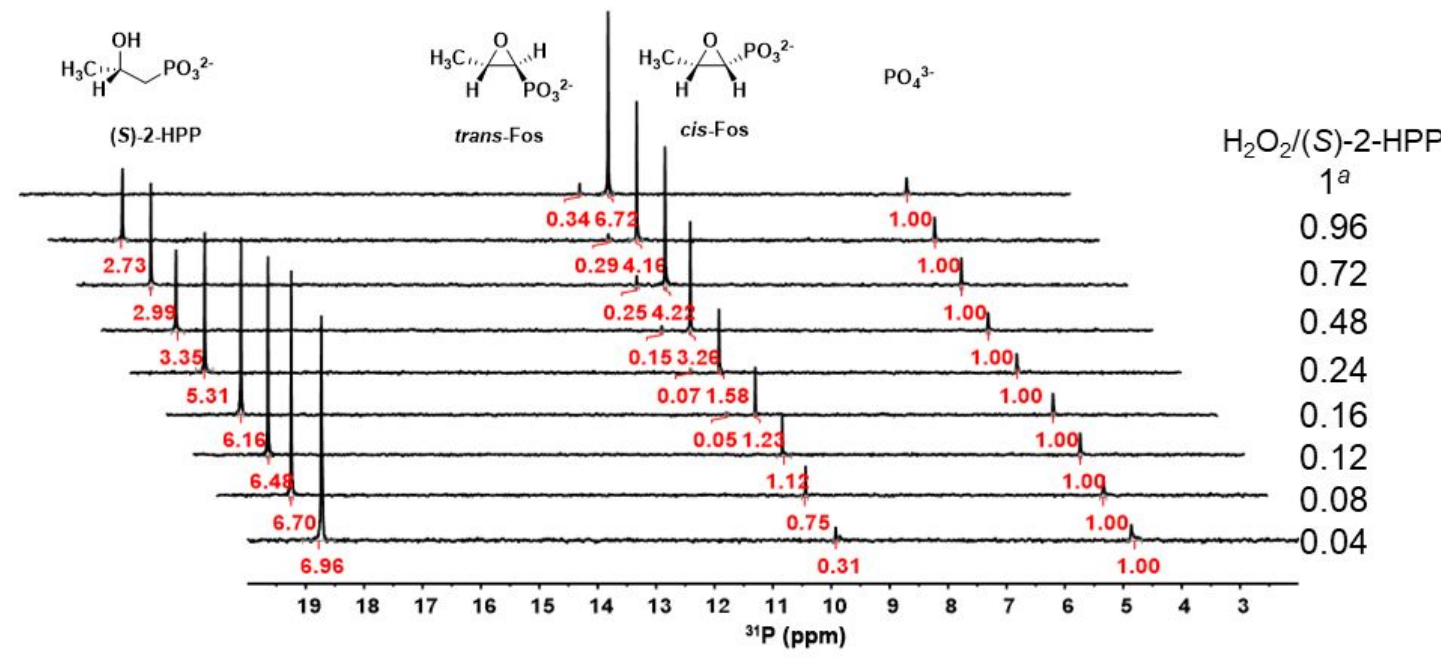

B

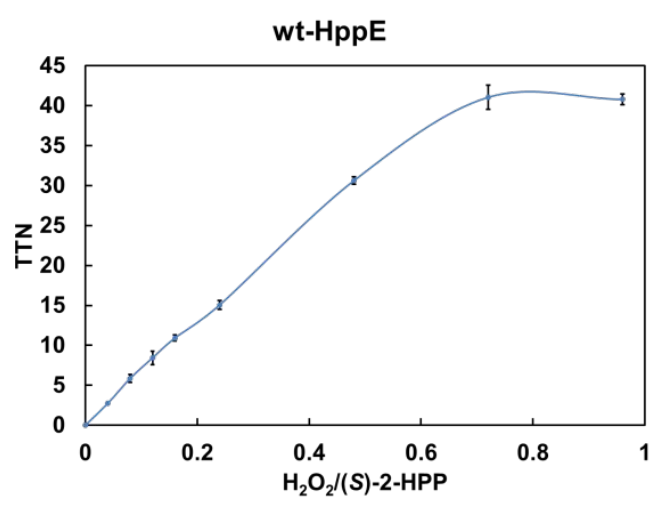

C

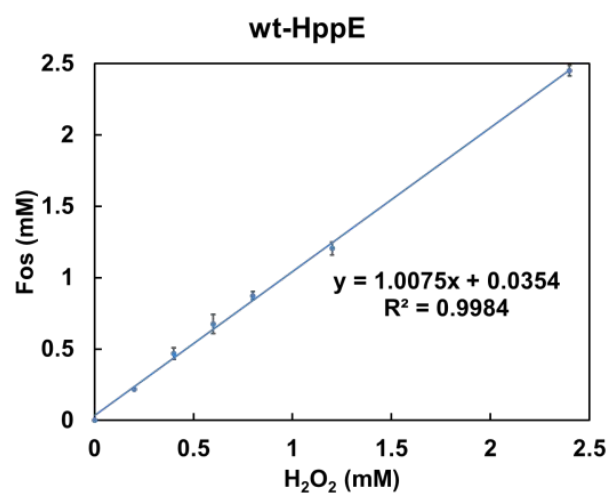


D

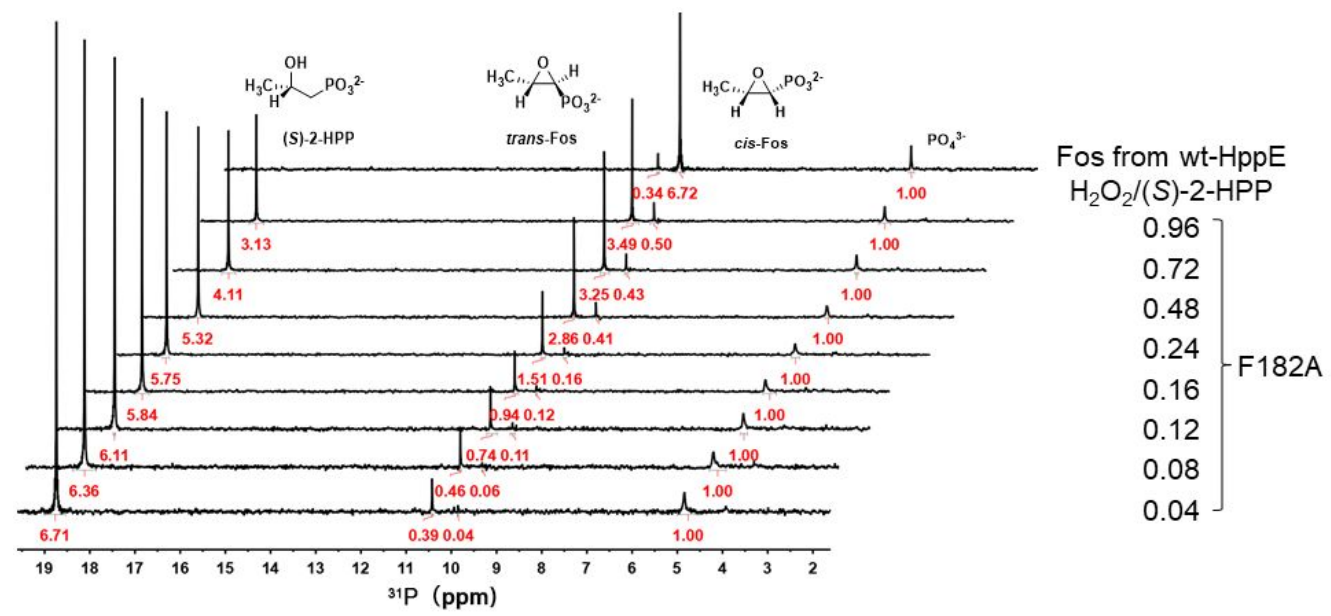

E

F182A

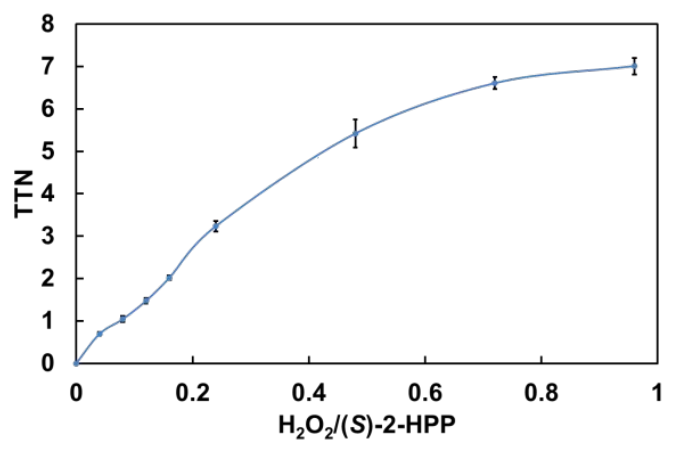

F

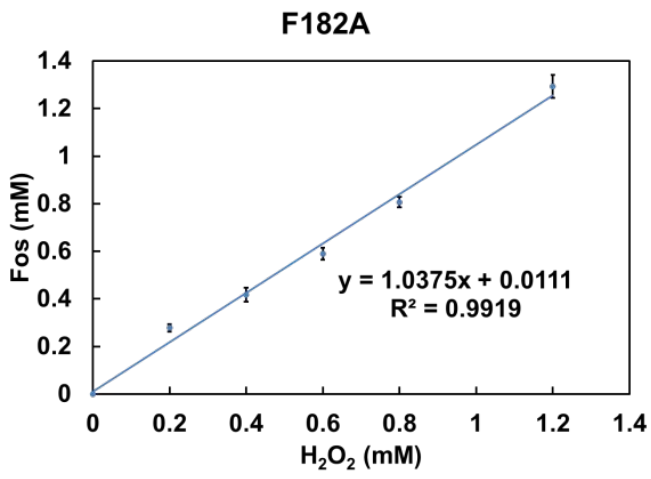


G

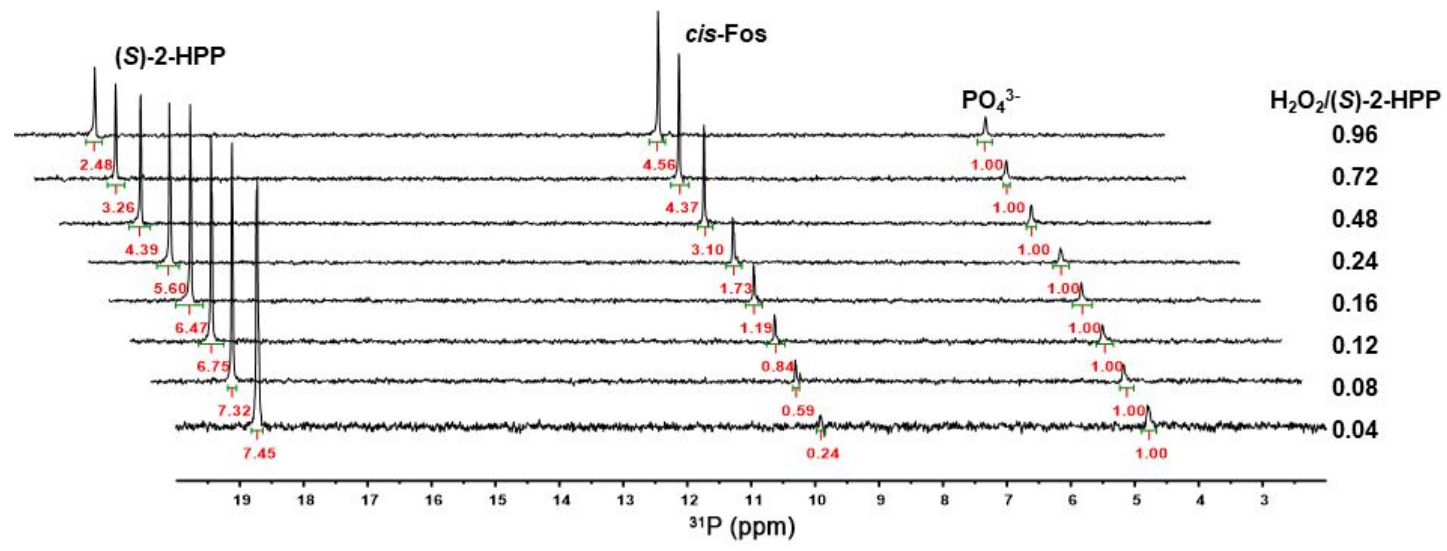

$\mathbf{H}$

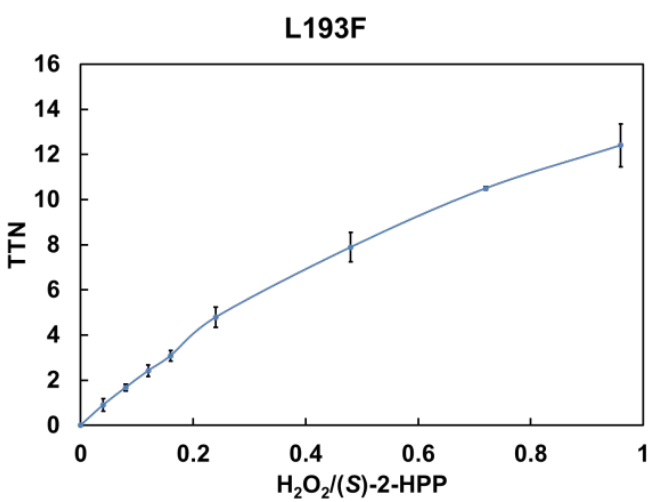

I

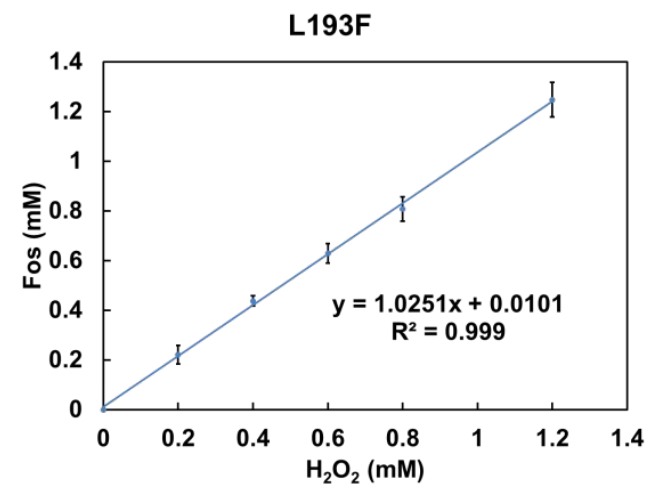

Figure S5. ${ }^{31} \mathrm{P}$ NMR analyses of the reactions of (S)-2-HPP with wild-type HppE and its F182A and L193F variants. Panels $\boldsymbol{A}-\boldsymbol{C}$ depict results for the wild-type enzyme, $\boldsymbol{D}-\boldsymbol{F}$ the F182A variant, and $\boldsymbol{G}-\boldsymbol{I}$ the L193F variant. The ${ }^{31}$ PCPD NMR spectra show single peaks at $\delta \sim 18.7 \mathrm{ppm}$ from $(S)-2-\mathrm{HPP}, \sim 10.4 \mathrm{ppm}$ from trans-Fos (3), 9.9 ppm from cis-Fos (2) and $\sim 4.8 \mathrm{ppm}$ from the internal standard $\mathrm{PO}_{4}{ }^{3-}$. Panels $\boldsymbol{B}$, $\boldsymbol{E}$, and $\boldsymbol{H}$ plot turnover number (TTN) $\left(y\right.$-axis) versus the ratio of $\mathrm{H}_{2} \mathrm{O}_{2} /(S)$-2-HPP ( $x$-axis) for the three enzymes (in the same order). Panels $\boldsymbol{C}, \boldsymbol{F}$, and $\boldsymbol{I}$ plot the sum of the concentrations of the two Fos products versus concentration $\mathrm{H}_{2} \mathrm{O}_{2}$ added. The slope of these lines yields the $\mathrm{Fos} / \mathrm{H}_{2} \mathrm{O}_{2}$ reaction stoichiometry, which is in all three cases indistinguishable from unity. The error bars are the standard deviations from the mean values of the three measurements performed at each concentration. ${ }^{a}$ same condition except using $0.2 \mathrm{mM}$ wt-HppE, $0.16 \mathrm{mM} \mathrm{Fe}$ (II , top line $)$. 


\subsection{Analysis of stereochemistry of (S)-2-HPP cyclization by HppE and variants.}

The specific reaction conditions for each experiment are shown in Table S2 below. The concentrations of products, their cis:trans ratios, and the conversions were calculated by comparison to the standard curves above. TTNs were calculated relative to $\mathrm{Fe}^{\mathrm{II}}$ concentration. Each reaction was performed in triplicate. Selected spectra can be found in Figure S6.

Table S2. ${ }^{31} \mathrm{P}$ NMR analysis of the reactions of $(S)-2-\mathrm{HPP}$ with HppE and variants. [Fe-E] = concentration of $\mathrm{Fe}(\mathrm{II}) \bullet e n z y m e$ complex. [Sub] = concentration of substrate in the reaction. Sub/IS, trans/IS, and cis/IS are quantities of substrate, trans-Fos (3) and cis-Fos (2), respectively, relative to the internal standard as calculated from the integrated intensities of the peaks arising from each compound in the NMR spectra. $[\mathrm{Pdt}]=$ calculated concentration of combined products, $\operatorname{cis} \%=$ cis-product ratio. Conv $\%=$ calculated conversion.

\begin{tabular}{|c|c|c|c|c|c|c|c|c|c|c|}
\hline Entry & $\mathrm{E}$ & $\begin{array}{l}{[\mathrm{Fe}-\mathrm{E}]} \\
(\mathrm{mM})\end{array}$ & $\begin{array}{l}{[\mathrm{Sub}]} \\
(\mathrm{mM})\end{array}$ & Sub/IS & trans/IS & cis/IS & $\begin{array}{l}{[\mathrm{Pdt}]} \\
(\mathrm{mM})\end{array}$ & TTN & $\operatorname{cis}(\%)$ & Conv( $\%)$ \\
\hline 1 & L193F & 0.4 & 3.6 & $0.75 \pm 0.03$ & $0.00 \pm 0.00$ & $4.57 \pm 0.80$ & $3.56 \pm 0.63$ & $8.9 \pm 1.6$ & $100 \pm 0.0$ & $85.3 \pm 2.4$ \\
\hline 2 & wt & 0.16 & 4.5 & $0.00 \pm 0.00$ & $0.33 \pm 0.03$ & $5.94 \pm 0.48$ & $4.89 \pm 0.39$ & $30.6 \pm 2.4$ & $94.7 \pm 0.3$ & $100 \pm 0$ \\
\hline 3 & L120F & 0.4 & 4.5 & $2.11 \pm 0.34$ & $0.66 \pm 0.02$ & $3.02 \pm 0.26$ & $2.87 \pm 0.19$ & $7.2 \pm 0.5$ & $81.9 \pm 1.7$ & $63.8 \pm 5.4$ \\
\hline 4 & F182A & 0.8 & 4 & $0.31 \pm 0.02$ & $4.21 \pm 0.31$ & $0.64 \pm 0.07$ & $3.78 \pm 0.30$ & $4.7 \pm 0.4$ & $12.8 \pm 0.6$ & $94.0 \pm 0.2$ \\
\hline
\end{tabular}

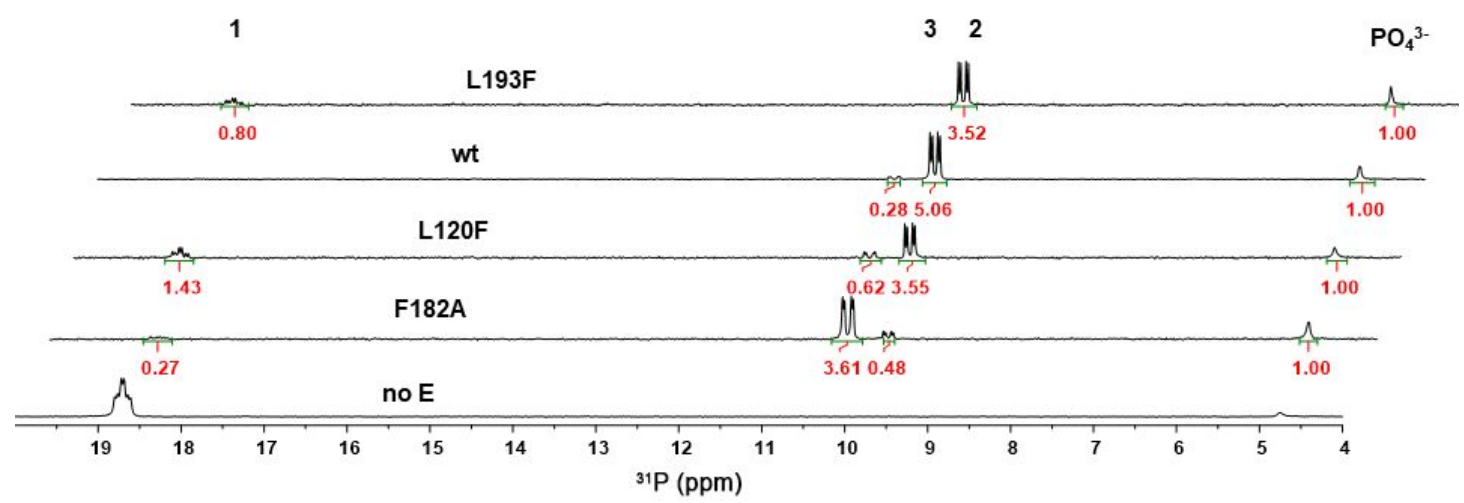

Figure S6. Selected ${ }^{31} \mathrm{P}$ NMR spectra of reactions of $(S)$-2-HPP with HppE and its variants. The doublet of doublet of doublets at $\sim 18.71 \mathrm{ppm}(\mathrm{ddd}, J=15.9,7.0 \mathrm{~Hz})$ is from $(S)$-2-HPP. The doublet of doublets at $\sim 10.4$ and $\sim 9.9 \mathrm{ppm}$ are from trans-Fos (3) and cis-Fos (2), respectively. The single peak at $\sim 4.8 \mathrm{ppm}$ is from the internal standard $\left(\mathrm{PO}_{4}^{3-}\right)$. 
3.6 Demonstration that F182A and L193F variants still abstract the pro- $R$ hydrogen.
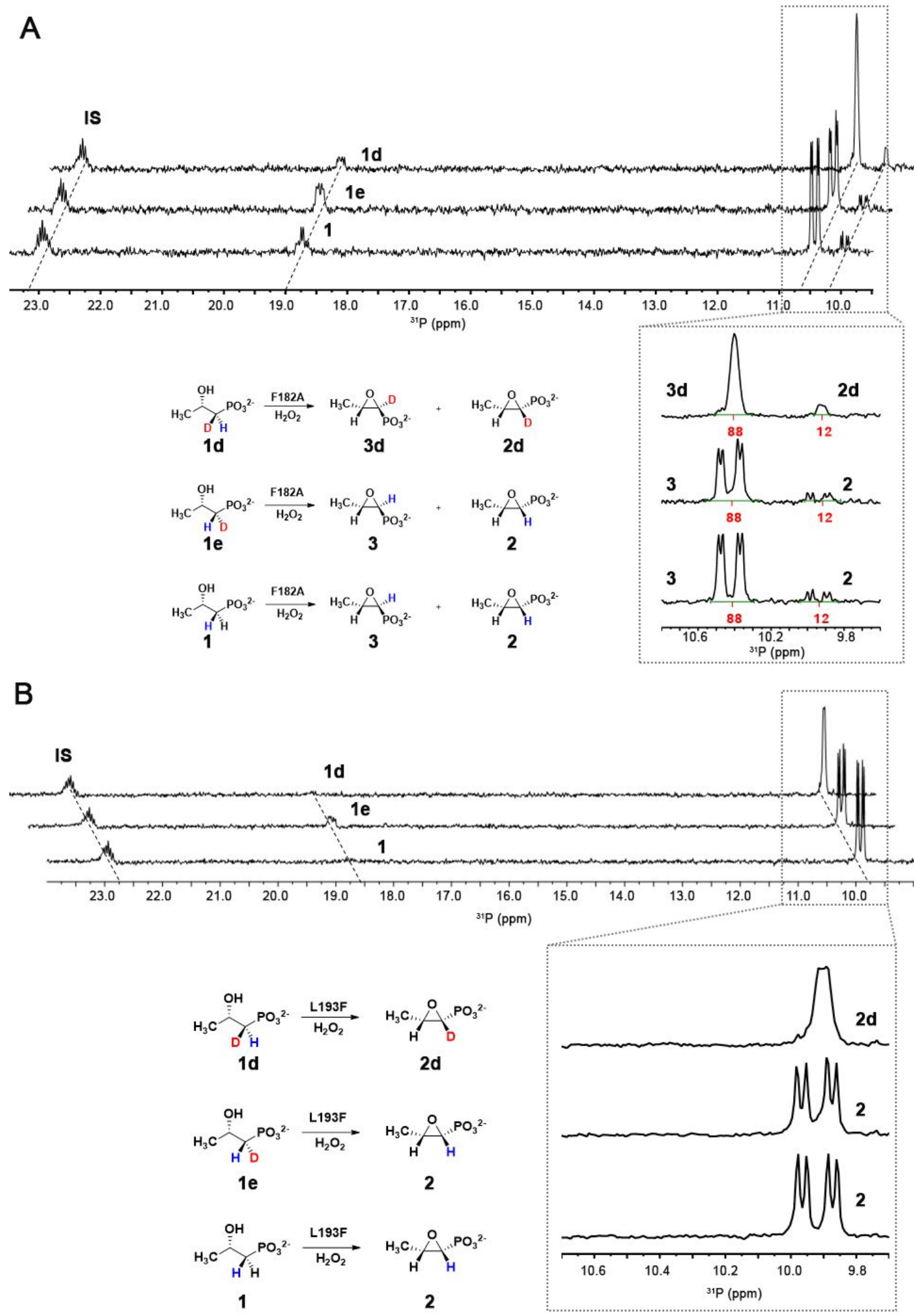

Figure S7. Selected ${ }^{31} \mathrm{P}$ NMR spectra of reactions of the F182A $(\boldsymbol{A})$ and L193F $(\boldsymbol{B})$ variants with $1 S-d$ $2 S$-HPP (1d) (top lines), $1 R$ - $d$-2S-HPP (1e) (middle lines) and $(S)$-2-HPP (1) (bottom lines). The reaction 
conditions were as described in $\mathrm{Sec} 2.4$, but $0.4 \mathrm{mM}$ of each $\mathrm{Fe}(\mathrm{II})$-reconstituted variant protein was used. The multiplet at $\sim 23.0 \mathrm{ppm}$ is from the internal standard sodium propylphosphonate. The doublet of doublet of doublets $\left({ }^{2} J_{\mathrm{P}-\mathrm{H}}=\sim 16,{ }^{3} J_{\mathrm{P}-\mathrm{H}}=\sim 7 \mathrm{~Hz}\right)$ at $\sim 18.6 \mathrm{ppm}$ is from 1 . The doublet of doublets $\left({ }^{2} J_{\mathrm{P}-}\right.$ $\left.{ }_{\mathrm{H}}=\sim 16,{ }^{3} J_{\mathrm{P}-\mathrm{H}}=\sim 7 \mathrm{~Hz}\right)$ at $\sim 18.6 \mathrm{ppm}$ is from $1 \mathrm{~d}$ and 1e. The doublet of doublets $\left({ }^{2} J_{\mathrm{P}-\mathrm{H}}=\sim 21,{ }^{3} J_{\mathrm{P}-\mathrm{H}}=\sim 5\right.$ $\mathrm{Hz})$ at $\sim 10.4 \mathrm{ppm}$ is from trans-Fos $(3)$. The doublet $\left({ }^{3} J_{\mathrm{P}-\mathrm{H}}=\sim 5 \mathrm{~Hz}\right)$ at $\sim 10.4 \mathrm{ppm}$ is from trans-1- $d$-Fos (3d). The doublet of doublets $\left({ }^{2} J_{\mathrm{P}-\mathrm{H}}=\sim 19,{ }^{3} J_{\mathrm{P}-\mathrm{H}}=\sim 5 \mathrm{~Hz}\right)$ at $\sim 9.9 \mathrm{ppm}$ is from $c i s-$ Fos $(2)$, and the doublet $\left({ }^{3} J_{\mathrm{P}-\mathrm{H}}=\sim 5 \mathrm{~Hz}\right)$ at $\sim 9.9 \mathrm{ppm}$ is from $c i s-1-d-\mathrm{Fos}(\mathbf{2 d})$. The Scheme in the figures summarizes the reaction outcomes. 
4. Use of halogen substitution to distinguish between polar and radicaloid C-O-coupling mechanisms.

4.1 Isolation and characterization of products generated by HppE from $(S)-3-F_{3}-\mathrm{HPP}(1 \mathrm{c})$.

A

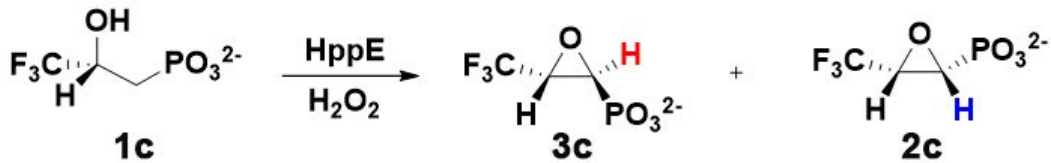

B

Synthetic std. (rac-2c)

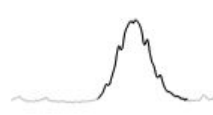

Synthetic std. (rac-3c)

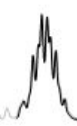

Isolated products $(3 c$ and $2 c)$ from the HppE reaction

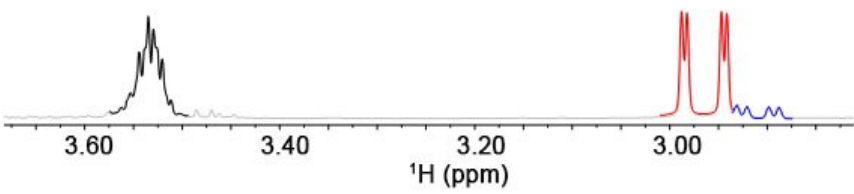

C
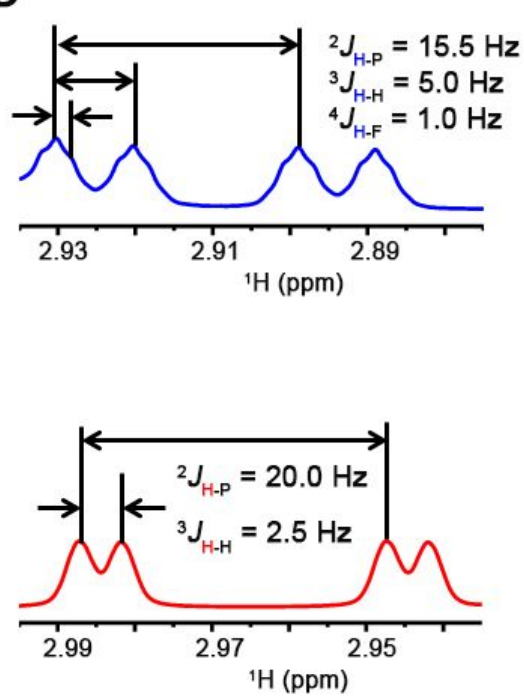

Figure S8. Analysis of the products generated by $\mathrm{HppE}$ from $(S)-3-\mathrm{F}_{3}-2-\mathrm{HPP}(\mathbf{1 c})$. (A) Reaction scheme showing two possible products. (B) ${ }^{1} \mathrm{H}$ NMR spectra of isolated cis/trans-F $-\mathrm{Fos}(\mathbf{2 c} / \mathbf{3 c})$ generated by

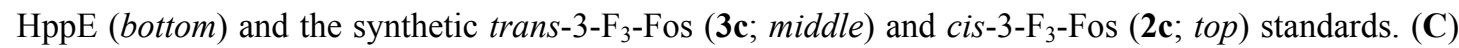
Blow-up of the ${ }^{1} \mathrm{H}$ NMR spectra of isolated $3-\mathrm{F}_{3}-\mathrm{Fos}$ products showing vicinal and geminal couplings. ${ }^{3} J_{\mathrm{H}-\mathrm{H}}$ of $c i s-3-\mathrm{F}_{3}-\mathrm{Fos}(\mathbf{2 c})$ is $\sim 5 \mathrm{~Hz}$, and ${ }^{3} J_{\mathrm{H}-\mathrm{H}}$ of trans $-\mathrm{F}_{3}-\mathrm{Fos}(\mathbf{3 c})$ is $\sim 3 \mathrm{~Hz}$. The reaction conditions and isolation procedure are described in $\operatorname{Sec} 2.2$, except that the final concentration of substrate was $3 \mathrm{mM}$.

(1S,2S)-1,2-epoxy-3,3,3-trifluoropropylphosphate (3c): ${ }^{1} \mathrm{H}$ NMR $\left(500 \mathrm{MHz}, \mathrm{D}_{2} \mathrm{O}\right) \delta 3.67-3.62(\mathrm{~m}$, 1H), $3.08(\mathrm{dd}, J=20.0,2.5 \mathrm{~Hz}, 1 \mathrm{H}) .{ }^{31} \mathrm{P} \mathrm{NMR}\left(202 \mathrm{MHz}, \mathrm{D}_{2} \mathrm{O}\right) \delta 6.70(\mathrm{dd}, J=19.9,4.3 \mathrm{~Hz}) .{ }^{19} \mathrm{~F}$ NMR $\left(471 \mathrm{MHz}, \mathrm{D}_{2} \mathrm{O}\right) \delta-74.27(\mathrm{~d}, J=4.7 \mathrm{~Hz}) .{ }^{13} \mathrm{C}$ NMR $\left(126 \mathrm{MHz}, \mathrm{D}_{2} \mathrm{O}\right) \delta 122.87(\mathrm{q}, J=275.9 \mathrm{~Hz}), 52.54$ (q, $J=40.5 \mathrm{~Hz}), 51.25(\mathrm{~d}, J=170.3 \mathrm{~Hz})$. HRMS (ESI): calcd for $\mathrm{C}_{3} \mathrm{H}_{3} \mathrm{~F}_{3} \mathrm{O}_{4} \mathrm{P}\left(\mathrm{M}-\mathrm{H}^{-}\right)$190.9726, found 190.9732. 


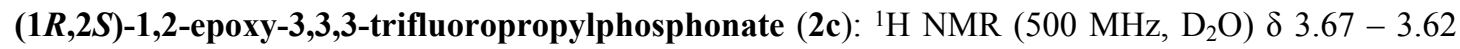
(m, 1H), $3.02(\mathrm{~m}, J=15.5,5.0,1.0 \mathrm{~Hz}, 1 \mathrm{H}) .{ }^{31} \mathrm{P}$ NMR $\left(202 \mathrm{MHz}, \mathrm{D}_{2} \mathrm{O}\right) \delta 5.27(\mathrm{dd}, J=15.9,2.3 \mathrm{~Hz})$. ${ }^{19} \mathrm{~F}$ NMR (471 MHz, $\left.\mathrm{D}_{2} \mathrm{O}\right) \delta-67.31(\mathrm{~d}, J=6.7 \mathrm{~Hz})$.

A

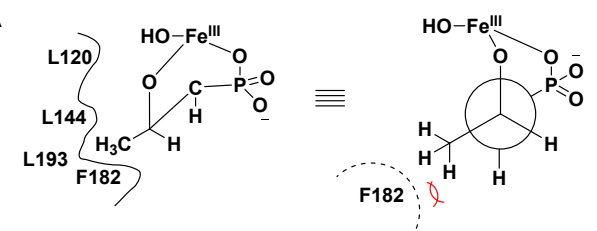

disfavored

C

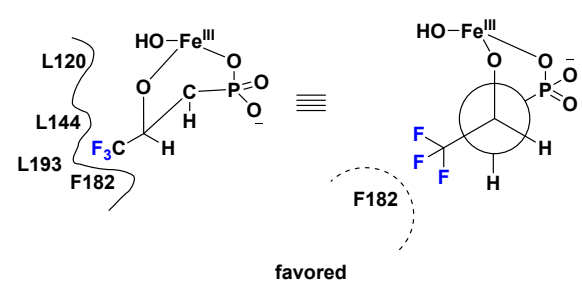

B

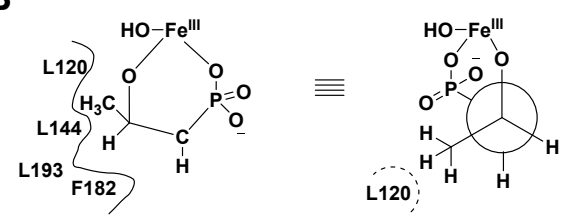

favored

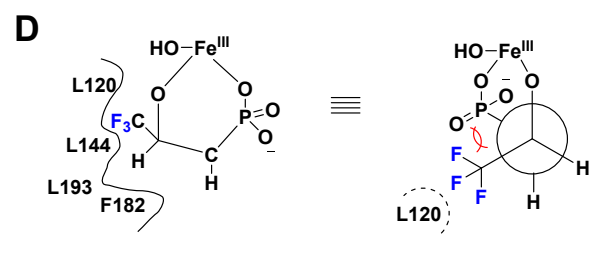

disfavored

Figure S9. Explanation for the favored transition state $(\boldsymbol{B})$ for $c i s-F o s(2)$ formation by $\mathrm{C} 1$ inversion and the favored transition state $(\boldsymbol{C})$ for trans $-3-\mathrm{F}_{3}-\mathrm{Fos}(\mathbf{3 c})$ formation by $\mathrm{C} 1$ retention in the active pocket of wild-type HppE.

\subsection{Stereochemical course of the cyclization of (S)-3-F $-2-H P P(1 c)$ by HppE and variants.}

Table S3. The standard curves of $(S)-3-\mathrm{F}_{3}-\mathrm{HPP}$ by ${ }^{31} \mathrm{P}$ and ${ }^{19} \mathrm{~F}$ NMR with representative spectra are shown below. The method is as described in the caption of Table S1.

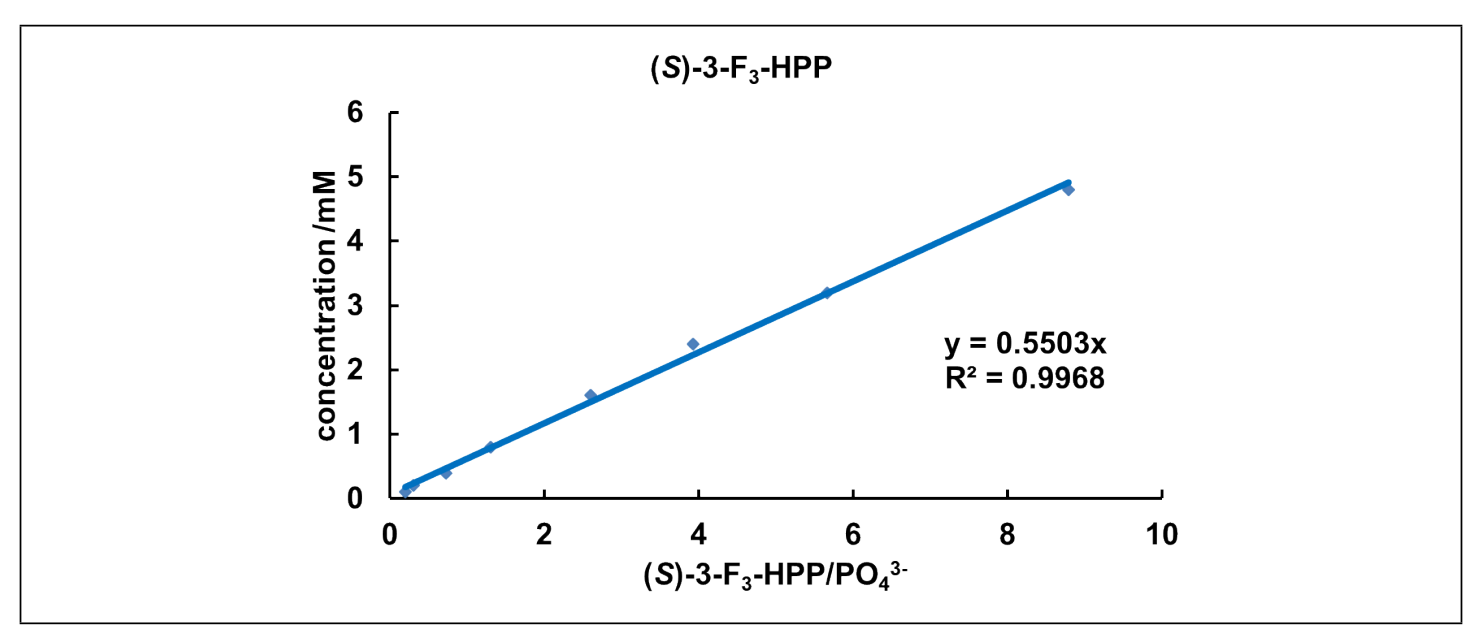




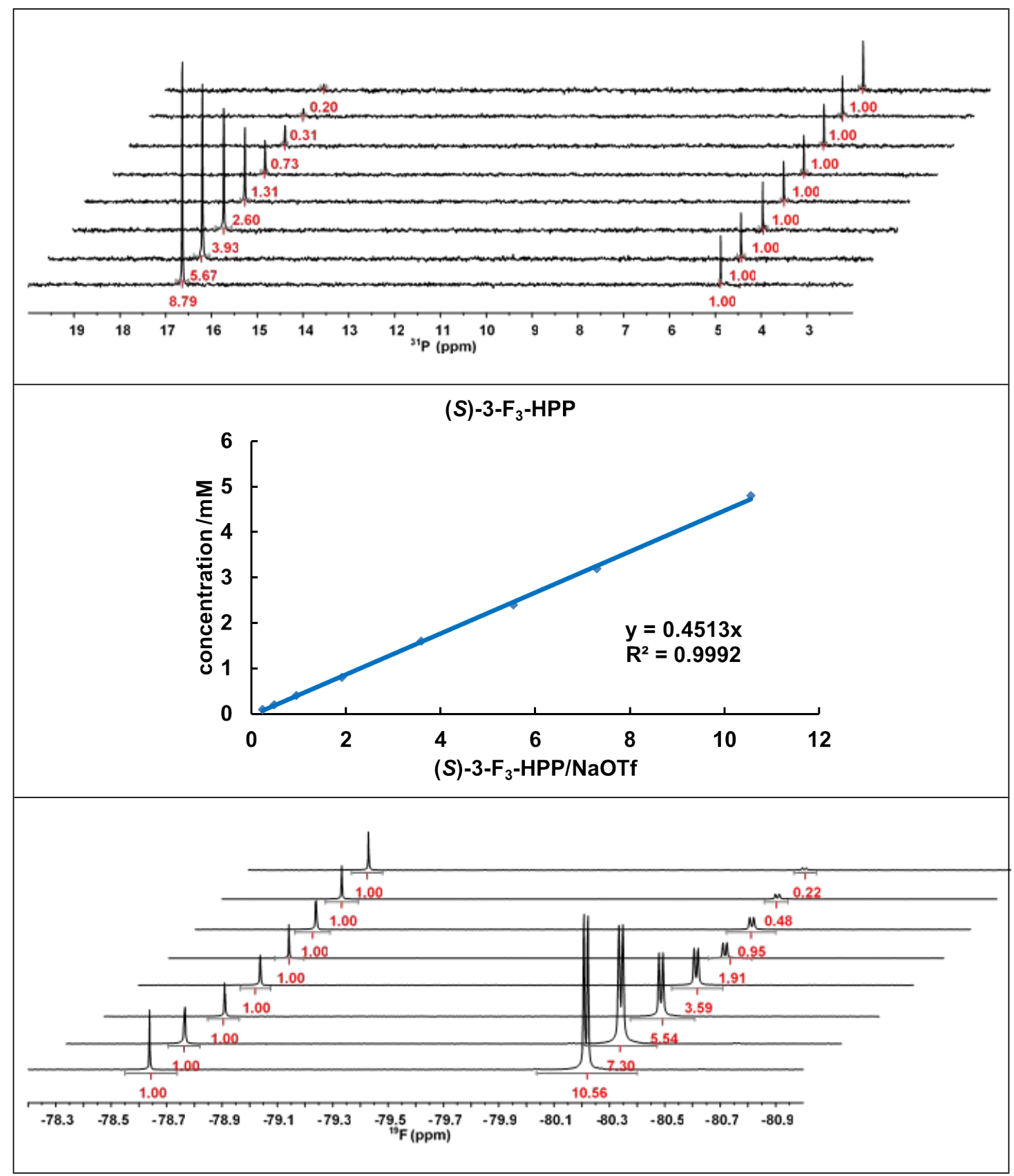

Table S4. ${ }^{31} \mathrm{P}$ NMR analysis of the reactions of $(S)-3-\mathrm{F}_{3}-2-\mathrm{HPP}(\mathbf{1 c})$ with HppE and variants. Column headings are as described in the caption of Table S2.

\begin{tabular}{|c|c|c|c|c|c|c|c|c|c|c|}
\hline Entry & E & $\begin{array}{l}{[\mathrm{Fe}-\mathrm{E}]} \\
(\mathrm{mM})\end{array}$ & $\begin{array}{l}{[\mathrm{Sub}]} \\
(\mathrm{mM})\end{array}$ & Sub/IS & $\operatorname{trans} / \mathrm{IS}$ & cis/IS & $\begin{array}{l}{[\mathrm{Pdt}]} \\
(\mathrm{mM})\end{array}$ & TTN & cis(\%) & Conv $(\%)$ \\
\hline 1 & $\begin{array}{l}\text { L193F/ } \\
\text { L144F }\end{array}$ & 0.8 & 1.5 & $1.29 \pm 0.07$ & $0.12 \pm 0.01$ & $1.10 \pm 0.17$ & $0.80 \pm 0.11$ & $1.0 \pm 0.1$ & $90.2 \pm 0.8$ & $48.1 \pm 2.2$ \\
\hline 2 & L193F & 0.4 & 3 & $1.44 \pm 0.41$ & $1.57 \pm 0.23$ & $2.04 \pm 0.31$ & $2.38 \pm 0.35$ & $6.0 \pm 0.9$ & $56.4 \pm 0.3$ & $72.9 \pm 3.7$ \\
\hline
\end{tabular}




\begin{tabular}{|c|c|c|c|c|c|c|c|c|c|c|}
\hline 3 & wt & 0.8 & 3 & $1.31 \pm 0.05$ & $2.49 \pm 0.10$ & $0.74 \pm 0.02$ & $2.13 \pm 0.08$ & $2.7 \pm 0.1$ & $22.8 \pm 0.2$ & $71.1 \pm 0.1$ \\
\hline 4 & L120F & 0.4 & 4 & $4.63 \pm 0.47$ & $1.75 \pm 0.10$ & $0.20 \pm 0.01$ & $1.28 \pm 0.06$ & $3.2 \pm 0.2$ & $10.2 \pm 0.9$ & $29.9 \pm 3.0$ \\
\hline 5 & F182A & 0.8 & 3 & $0.38 \pm 0.02$ & $2.47 \pm 0.10$ & $0.00 \pm 0.00$ & $1.63 \pm 0.06$ & $2.0 \pm 0.1$ & $0.0 \pm 0.0$ & $86.7 \pm 1.1$ \\
\hline
\end{tabular}

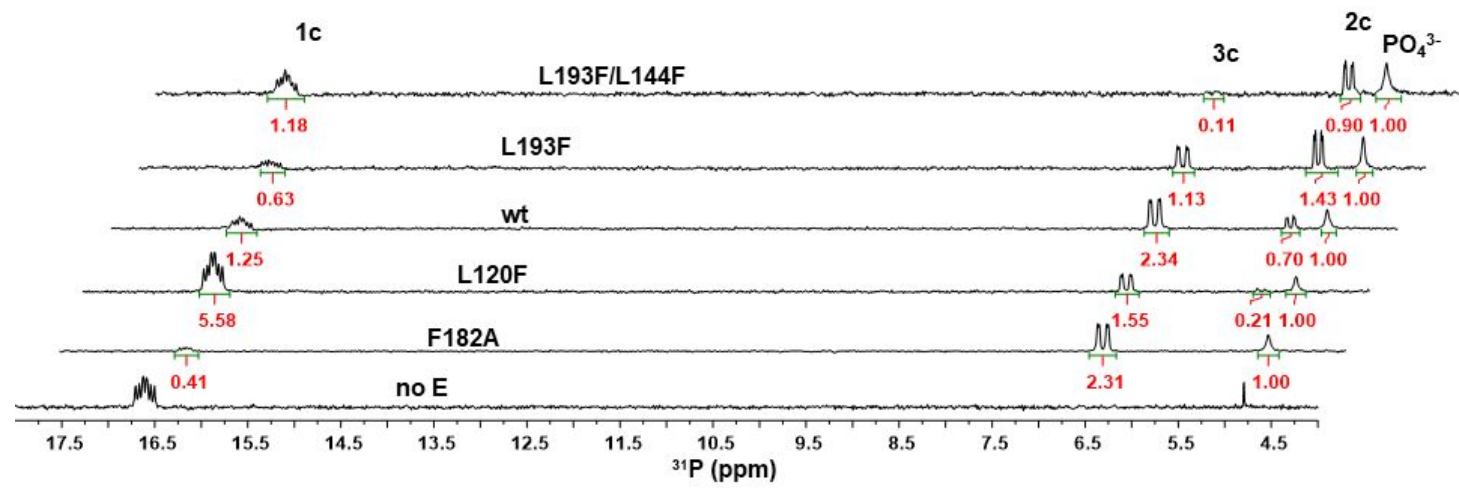

Figure S10. Selected ${ }^{31} \mathrm{P}-\mathrm{NMR}$ spectra of the reactions of $(S)-3-\mathrm{F}_{3}-2-\mathrm{HPP}(\mathbf{1 c})$ with HppE and variants. The multiplets at $\sim 16.6, \sim 6.7$ and $\sim 5.2 \mathrm{ppm}$ are from $(S)-3-\mathrm{F}_{3}-2-\mathrm{HPP}(\mathbf{1 c})$, trans-3- $\mathrm{F}_{3}-\mathrm{Fos}(\mathbf{3 c})$ and cis$3-\mathrm{F}_{3}$-Fos (2c), respectively. The single peak at $\sim 4.8 \mathrm{ppm}$ corresponds to the internal standard $\mathrm{PO}_{4}{ }^{3-}$.

Table S5. ${ }^{19} \mathrm{~F}$ NMR analysis of the reactions of $(S)-3-\mathrm{F}_{3}-2-\mathrm{HPP}$ with $\mathrm{HppE}$ and variants. Column headings are as described in the caption of Table S2.

\begin{tabular}{|c|c|c|c|c|c|c|c|c|c|c|}
\hline Entry & $\mathrm{E}$ & $\begin{array}{c}{[\mathrm{Fe}-\mathrm{E}]} \\
(\mathrm{mM})\end{array}$ & $\begin{array}{c}{[\mathrm{Sub}]} \\
(\mathrm{mM})\end{array}$ & $\mathrm{Sub} / \mathrm{IS}$ & $\mathrm{trans} / \mathrm{IS}$ & $\mathrm{cis} / \mathrm{IS}$ & $\begin{array}{c}{[\mathrm{Pdt}]} \\
(\mathrm{mM})\end{array}$ & $\mathrm{TTN}$ & cis(\%) & Conv(\%) \\
\hline 1 & L193F/ & 0.8 & 1.5 & $1.39 \pm 0.21$ & $0.14 \pm 0.02$ & $1.33 \pm 0.12$ & $0.79 \pm 0.07$ & $1.0 \pm 0.1$ & $90.7 \pm 0.4$ & $51.7 \pm 6.1$ \\
\hline 2 & L193F & 0.4 & 3 & $1.46 \pm 0.38$ & $1.80 \pm 0.04$ & $2.33 \pm 0.06$ & $2.23 \pm 0.05$ & $5.6 \pm 0.1$ & $56.3 \pm 0.3$ & $74.6 \pm 5.4$ \\
\hline 3 & $\mathrm{wt}$ & 0.8 & 3 & $1.05 \pm 0.38$ & $3.32 \pm 0.32$ & $0.83 \pm 0.03$ & $2.24 \pm 0.18$ & $2.8 \pm 0.2$ & $20.1 \pm 1.3$ & $80.1 \pm 6.9$ \\
\hline 4 & L120F & 0.4 & 4 & $4.15 \pm 0.02$ & 1.89 & $0.18 \pm 0.01$ & $1.12 \pm 0.01$ & $3.2 \pm 0.2$ & $8.7 \pm 0.5$ & $33.2 \pm 0.1$ \\
\hline 5 & F182A & 0.8 & 3 & $0.78 \pm 0.41$ & $2.15 \pm 0.29$ & $0.00 \pm 0.00$ & $1.16 \pm 0.16$ & $1.4 \pm 0.2$ & $0.0 \pm 0.0$ & $74.3 \pm 12.4$ \\
\hline
\end{tabular}




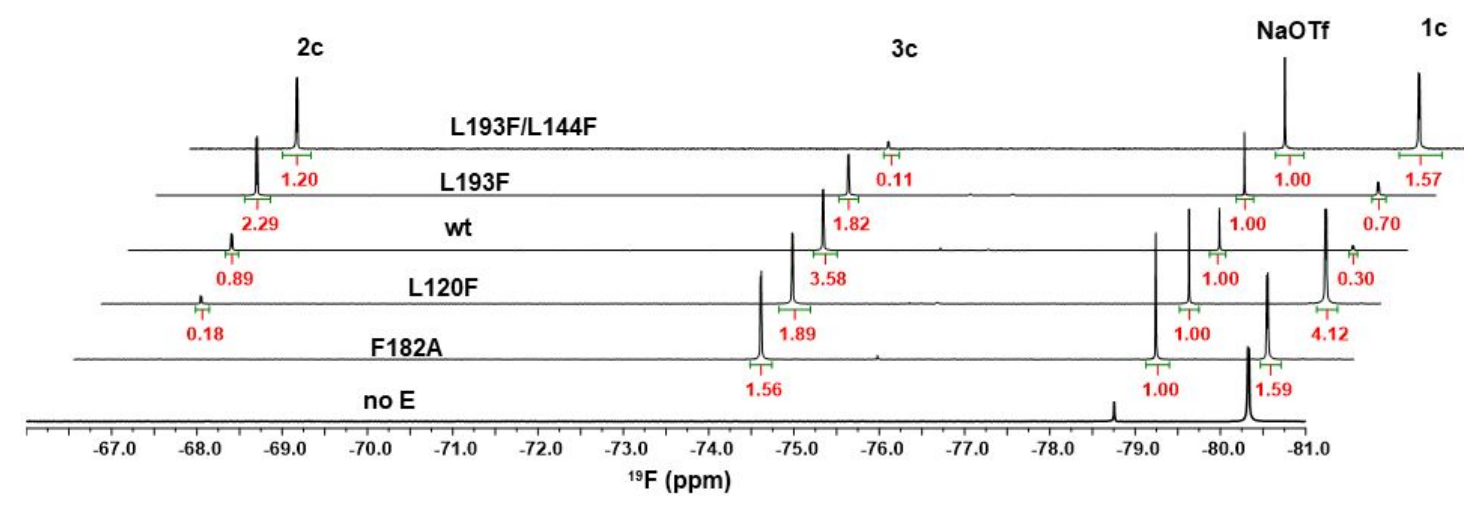

Figure S11. Selected ${ }^{19}$ F-NMR spectra of the reactions of $(S)-3-\mathrm{F}_{3}-2-\mathrm{HPP}(\mathbf{1 c})$ with HppE and variants. The doublets at $\sim-67.2, \sim-74.1$ and $\sim-80.3$ are from $c i s-3-F_{3}-$ Fos $(\mathbf{2 c})$, trans $-3-\mathrm{F}_{3}-\mathrm{Fos}(\mathbf{3 c})$, and $(S)-3-$ $\mathrm{F}_{3}$-2-HPP (1c), respectively. The single peak at $\sim-78.7$ corresponds to the internal standard, NaOTf. 
4.3 Characterization of the products generated by HppE from $(S)-3-F-2-H P P(1 a)$ and $(S)-3-F_{2}-2-$ HPP (1b).

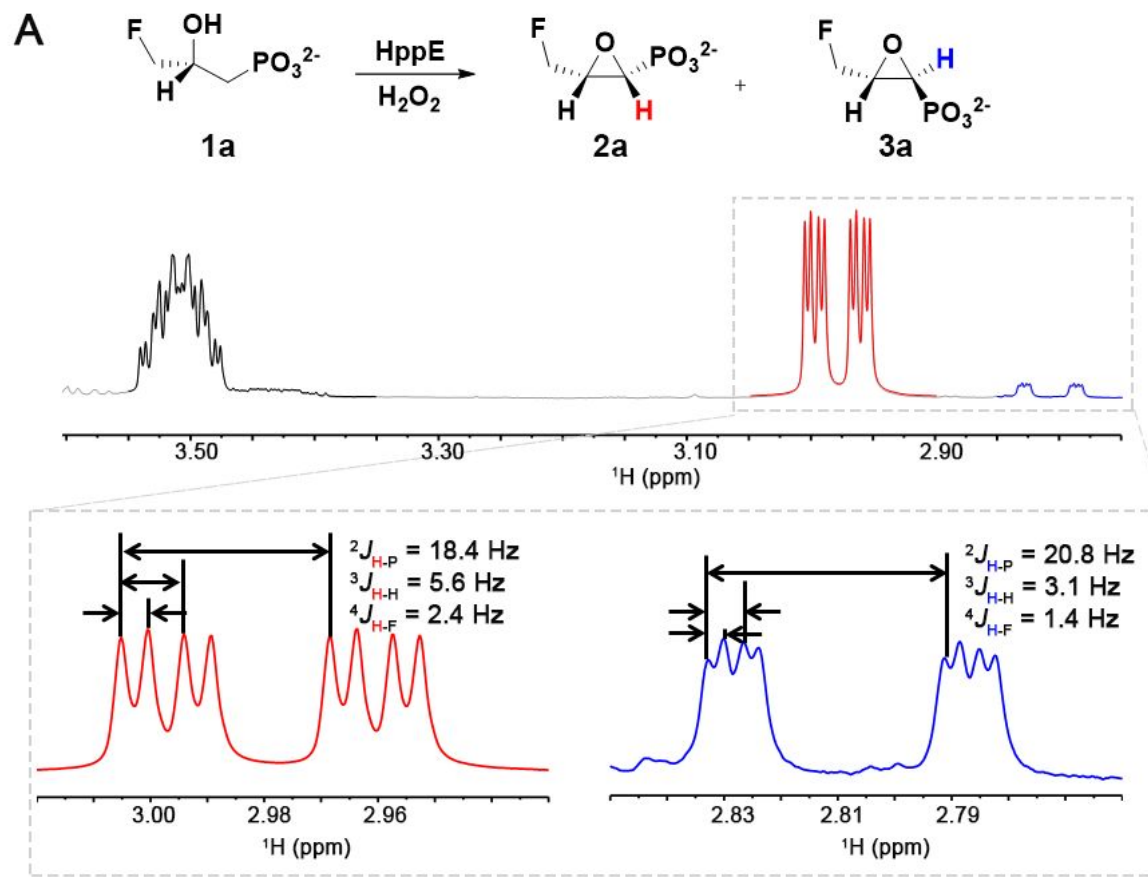

B

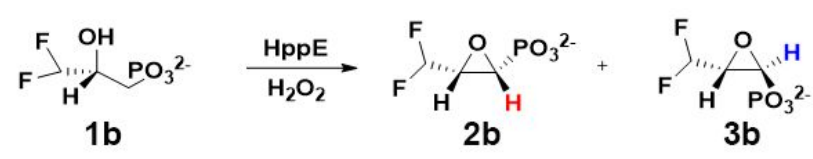
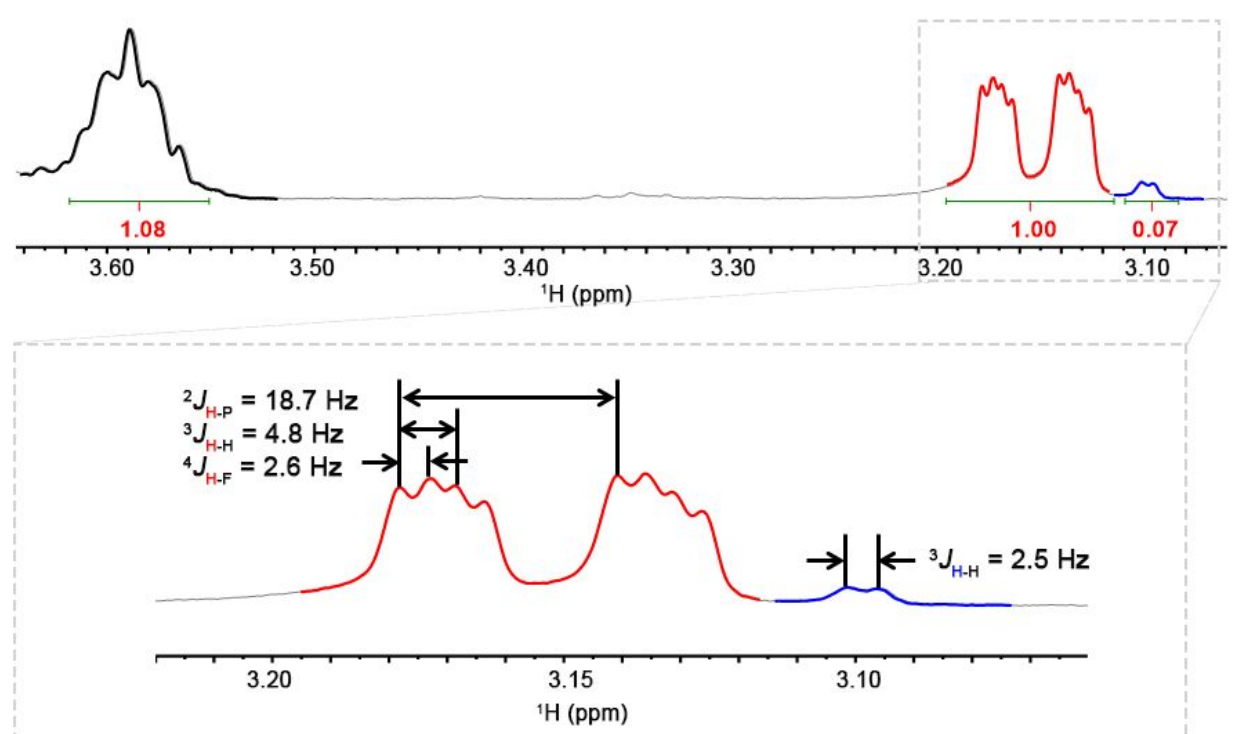

Figure S12. Reaction schemes (top) and ${ }^{1} \mathrm{H}-\mathrm{NMR}$ spectra of isolated products (bottom) for reactions of (A) $(S)-3-\mathrm{F}-2-\mathrm{HPP}$ and (B) $(S)-3-\mathrm{F}_{2}-2-\mathrm{HPP}$ by HppE. ${ }^{3} J_{\mathrm{H}-\mathrm{H}}$ for the cis epoxide is $\sim 5 \mathrm{~Hz}$, whereas that for the trans epoxide is $\sim 3 \mathrm{~Hz}$. 
(1R,2S)-1,2-epoxy-3-fluoropropylphosphonate (2a). ${ }^{1} \mathrm{H}$ NMR $\left(500 \mathrm{MHz}, \mathrm{D}_{2} \mathrm{O}\right) \delta$ 4.92-4.80 (m, 2H), $3.52-3.44(\mathrm{~m}, 1 \mathrm{H}), 2.95(\mathrm{ddd}, J=18.4,5.6,2.4 \mathrm{~Hz}, 1 \mathrm{H}) .{ }^{13} \mathrm{C}$ NMR $\left(126 \mathrm{MHz}, \mathrm{D}_{2} \mathrm{O}\right) \delta 83.85(\mathrm{~d}, J=$ $157.8 \mathrm{~Hz}), 55.45(\mathrm{~d}, J=25.1 \mathrm{~Hz}), 52.91(\mathrm{dd}, J=172.5,8.6 \mathrm{~Hz}) .{ }^{31} \mathrm{P}$ NMR $(202 \mathrm{MHz}, 100 \mathrm{mM}$ NaOD in $\left.\mathrm{D}_{2} \mathrm{O}\right) \delta 8.25(\mathrm{ddd}, J=18.4,4.5,2.5 \mathrm{~Hz}) .{ }^{19} \mathrm{~F}$ NMR $\left(471 \mathrm{MHz}, 100 \mathrm{mM} \mathrm{NaOD}\right.$ in $\left.\mathrm{D}_{2} \mathrm{O}\right) \delta-222.34(\mathrm{~m}, J=$ 47.6, 11.9, $2.8 \mathrm{~Hz}$ ). HRMS (ESI): calcd for $\mathrm{C}_{3} \mathrm{H}_{5} \mathrm{FO}_{4} \mathrm{P}\left(\mathrm{M}-\mathrm{H}^{-}\right)$154.9915, found 154.9919.

(1S,2S)-1,2-epoxy-3-fluoropropylphosphonate (3a). ${ }^{1} \mathrm{H}$ NMR $\left(500 \mathrm{MHz}, \mathrm{D}_{2} \mathrm{O}\right) \delta$ 4.92-4.80 (m, 2H, overlapped), $3.45-3.39(\mathrm{~m}, 1 \mathrm{H}), 2.81$ (ddd, $J=20.8,3.1,1.4 \mathrm{~Hz}, 1 \mathrm{H}) .{ }^{31} \mathrm{P}$ NMR $(202 \mathrm{MHz}, 100 \mathrm{mM}$ $\mathrm{NaOD}$ in $\left.\mathrm{D}_{2} \mathrm{O}\right) \delta 9.10(\mathrm{ddd}, J=20.2,5.0,5.0 \mathrm{~Hz}) .{ }^{19} \mathrm{~F}$ NMR $\left(471 \mathrm{MHz}, 100 \mathrm{mM}\right.$ NaOD in $\left.\mathrm{D}_{2} \mathrm{O}\right)-225.58$ $(\mathrm{m}, J=47.3,13.7,4.5 \mathrm{~Hz})$.

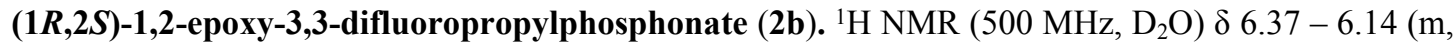
H), $3.46-3.42(\mathrm{~m}, 1 \mathrm{H}), 3.00(\mathrm{ddd}, J=18.7,4.8,2.6 \mathrm{~Hz}, 1 \mathrm{H}) .{ }^{13} \mathrm{C} \mathrm{NMR}\left(126 \mathrm{MHz}, \mathrm{D}_{2} \mathrm{O}\right) \delta 114.60(\mathrm{t}, J$ $=235.9 \mathrm{~Hz}), 54.44(\mathrm{dd}, J=42.6,30.5 \mathrm{~Hz}), 52.58(\mathrm{dd}, J=171.0,7.7 \mathrm{~Hz}) .{ }^{31} \mathrm{P}$ NMR $(202 \mathrm{MHz}, 100 \mathrm{mM}$ $\mathrm{NaOD}$ in $\left.\mathrm{D}_{2} \mathrm{O}\right) \delta 7.09(\mathrm{~J}=\mathrm{m}, 17.1,3.8,2.0 \mathrm{~Hz}) .{ }^{19} \mathrm{~F}$ NMR $\left(471 \mathrm{MHz}, 100 \mathrm{mM} \mathrm{NaOD}\right.$ in $\left.\mathrm{D}_{2} \mathrm{O}\right) \delta-118.26$ $(\mathrm{m}, J=310.4,57.7,7.4 \mathrm{~Hz}),-121.20(\mathrm{~m}, J=310.4,52.9 \mathrm{~Hz})$. HRMS (ESI): calcd for $\mathrm{C}_{3} \mathrm{H}_{4} \mathrm{~F}_{2} \mathrm{O}_{4} \mathrm{P}(\mathrm{M}-$ $\left.\mathrm{H}^{-}\right)$172.9820, found 172.9825 .

(1S,2S)-1,2-epoxy-3,3-difluoropropylphosphonate (3b). ${ }^{1} \mathrm{H}$ NMR $\left(500 \mathrm{MHz}, \mathrm{D}_{2} \mathrm{O}\right) \delta 6.30-6.10(\mathrm{~m}$, 1H, overlapped), $3.61-3.56$ (m, 1H, overlapped), $3.13-3.10$ (m, overlapped, $1 \mathrm{H}) .{ }^{31} \mathrm{P}$ NMR $(202 \mathrm{MHz}$, $100 \mathrm{mM} \mathrm{NaOD}$ in $\left.\mathrm{D}_{2} \mathrm{O}\right) \delta 7.78(\mathrm{~m}, J=20.1,4.9,2.6 \mathrm{~Hz}) .{ }^{19} \mathrm{~F}$ NMR $\left(471 \mathrm{MHz}, 100 \mathrm{mM} \mathrm{NaOD}\right.$ in $\left.\mathrm{D}_{2} \mathrm{O}\right)$ $-123.94(\mathrm{~m}, J=295.6,54.6,4.7 \mathrm{~Hz}),-125.36(\mathrm{~m}, J=295.8,55.2,9.4,2.8 \mathrm{~Hz})$ 
4.4 Stereochemical course of cyclization of $(S)-3-F-H P P$ and $(S)-3-F_{2}-H P P$ by HppE and variants.

Table S6. The standard curves of $(S)-3-\mathrm{F}-\mathrm{HPP}$ and $(S)-3-\mathrm{F}_{2}-\mathrm{HPP}$ by ${ }^{31} \mathrm{P}$ and ${ }^{19} \mathrm{~F}$ NMR with representative spectra are shown below. The method is as described in the caption of Table S1.

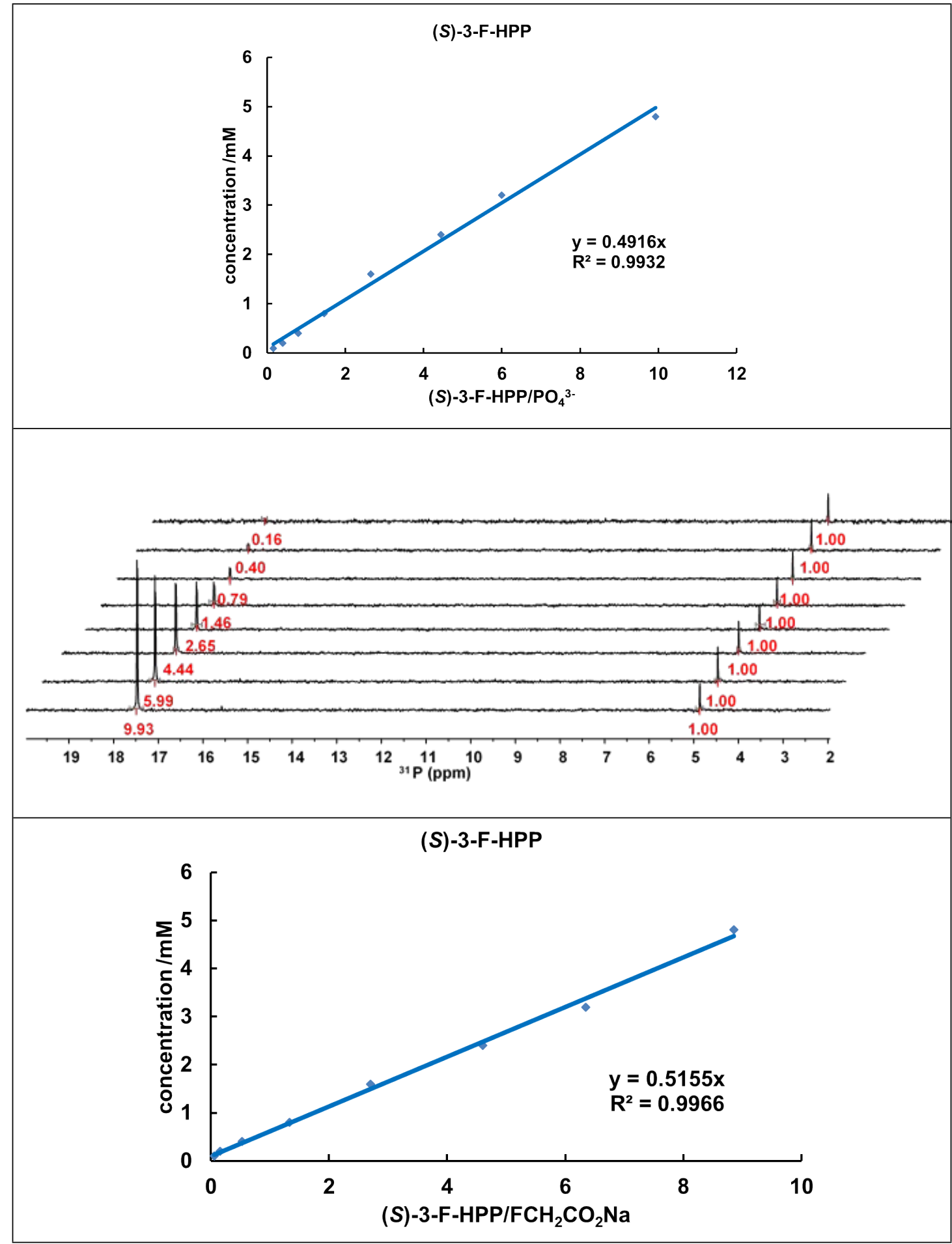




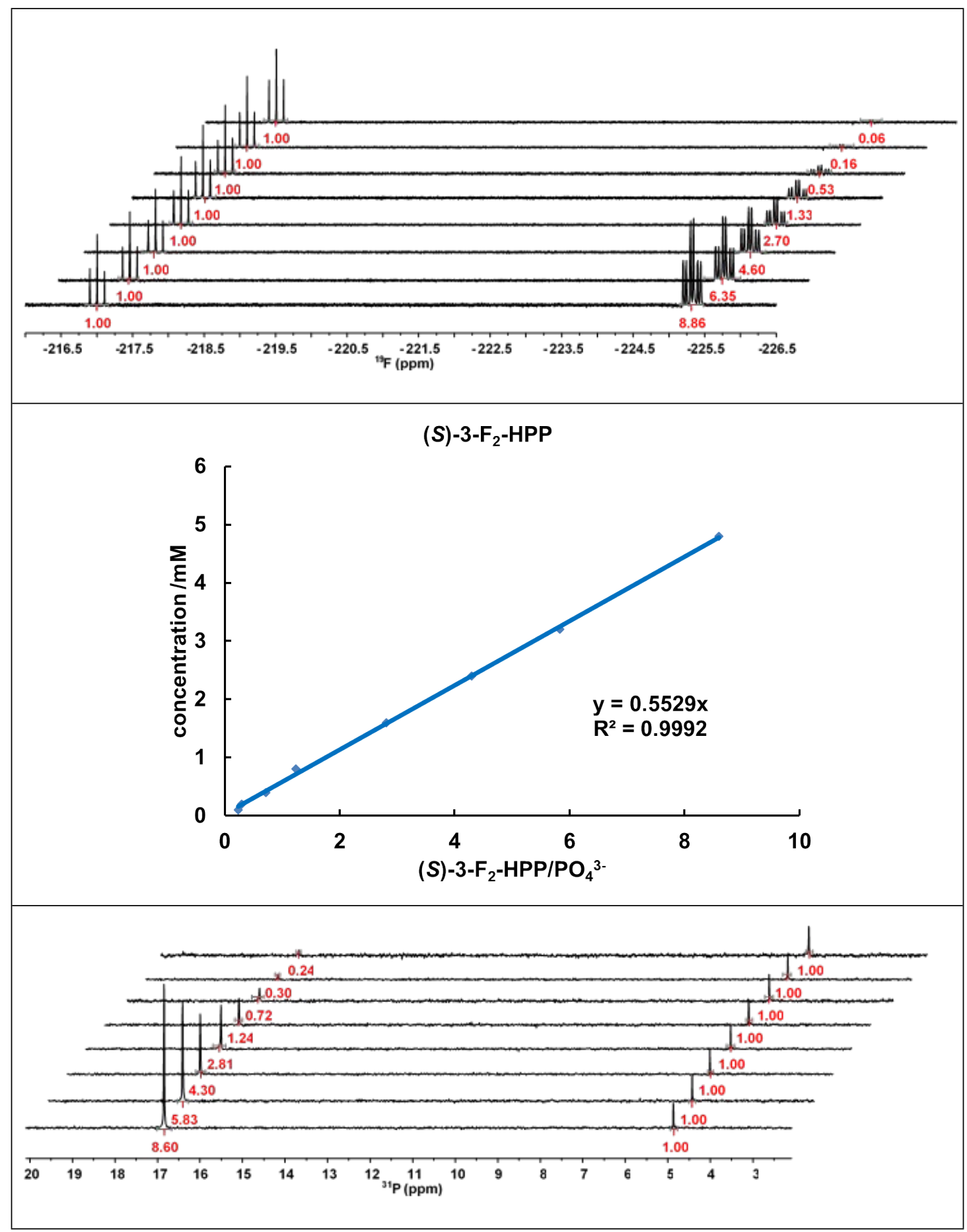




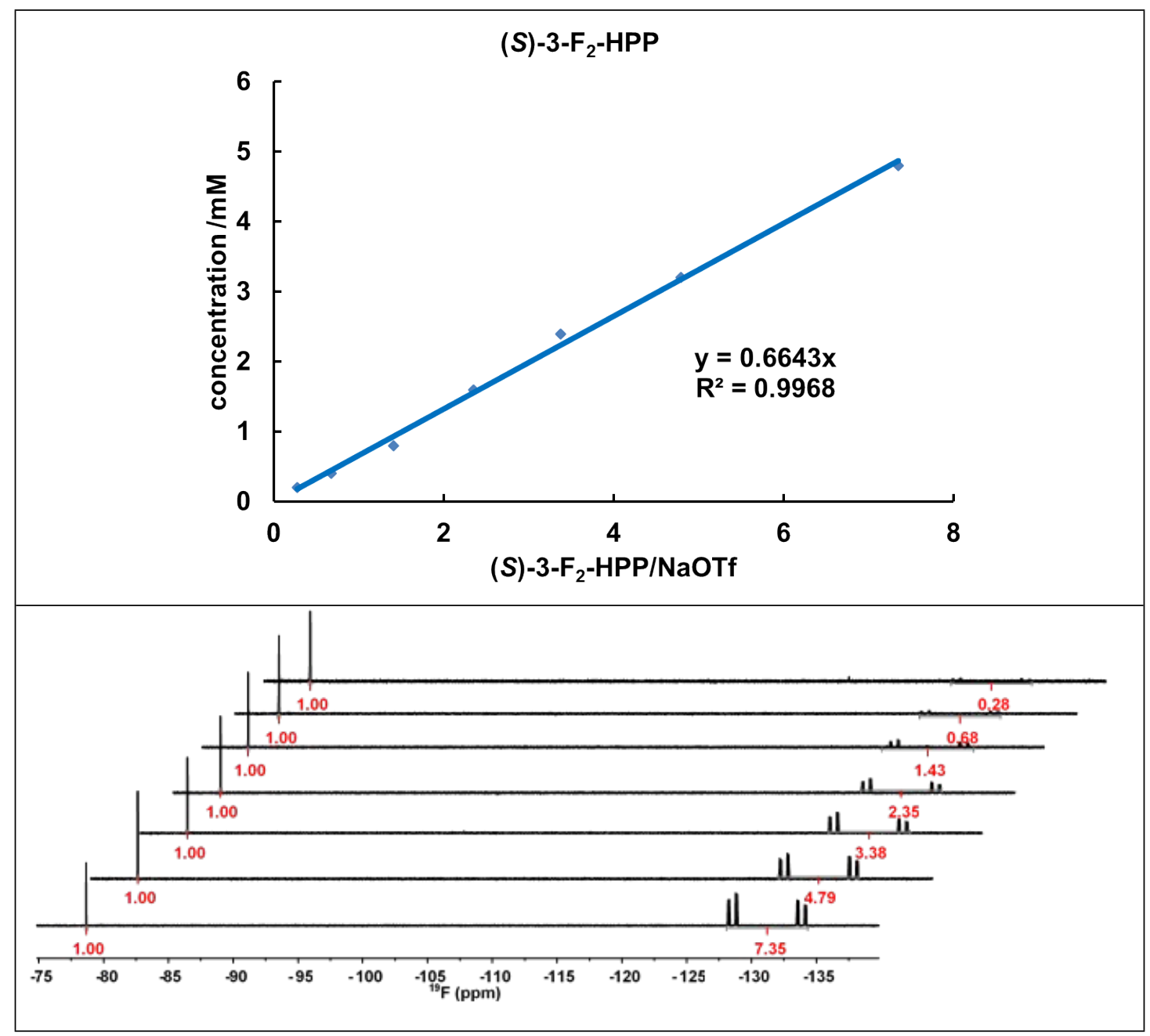

Table S7. ${ }^{31} \mathrm{P}$ NMR analysis of the reactions of $(S)-3-\mathrm{F}-2-\mathrm{HPP}$ with HppE and variants. Column headings are as described in the caption of Table S2.

\begin{tabular}{|c|c|c|c|c|c|c|c|c|c|c|}
\hline Entry & $\mathrm{E}$ & $\begin{array}{c}{[\mathrm{Fe}-\mathrm{E}]} \\
(\mathrm{mM})\end{array}$ & $\begin{array}{c}{[\mathrm{Sub}]} \\
(\mathrm{mM})\end{array}$ & $\mathrm{Sub} / \mathrm{IS}$ & trans/IS & $\begin{array}{c}\text { cis/IS } \\
(\mathrm{mM})\end{array}$ & $\begin{array}{c}\text { TTN } \\
\text { cis(\%) }\end{array}$ & Conv(\%) \\
\hline 1 & L193F & 0.4 & 1.5 & $0.44 \pm 0.14$ & $0.00 \pm 0.00$ & $1.59 \pm 0.08$ & $0.95 \pm 0.05$ & $2.4 \pm 0.1$ & $100 \pm 0.0$ & $78.9 \pm 5.3$ \\
\hline 2 & wt & 0.4 & 4 & $1.10 \pm 0.01$ & $0.35 \pm 0.02$ & $5.01 \pm 0.31$ & $3.22 \pm 0.39$ & $8.1 \pm 0.5$ & $93.4 \pm 0.3$ & $83.1 \pm 0.5$ \\
\hline 3 & L120F & 0.4 & 3.6 & $1.64 \pm 0.39$ & $0.47 \pm 0.02$ & $3.43 \pm 0.02$ & $2.34 \pm 0.02$ & $5.8 \pm 0.0$ & $87.9 \pm 0.4$ & $71.0 \pm 4.6$ \\
\hline 4 & F182A & 0.8 & 3 & $1.17 \pm 0.05$ & $4.04 \pm 0.16$ & $0.11 \pm 0.01$ & $2.49 \pm 0.09$ & $3.1 \pm 0.1$ & $2.7 \pm 0.2$ & $78.1 \pm 0.3$ \\
\hline
\end{tabular}




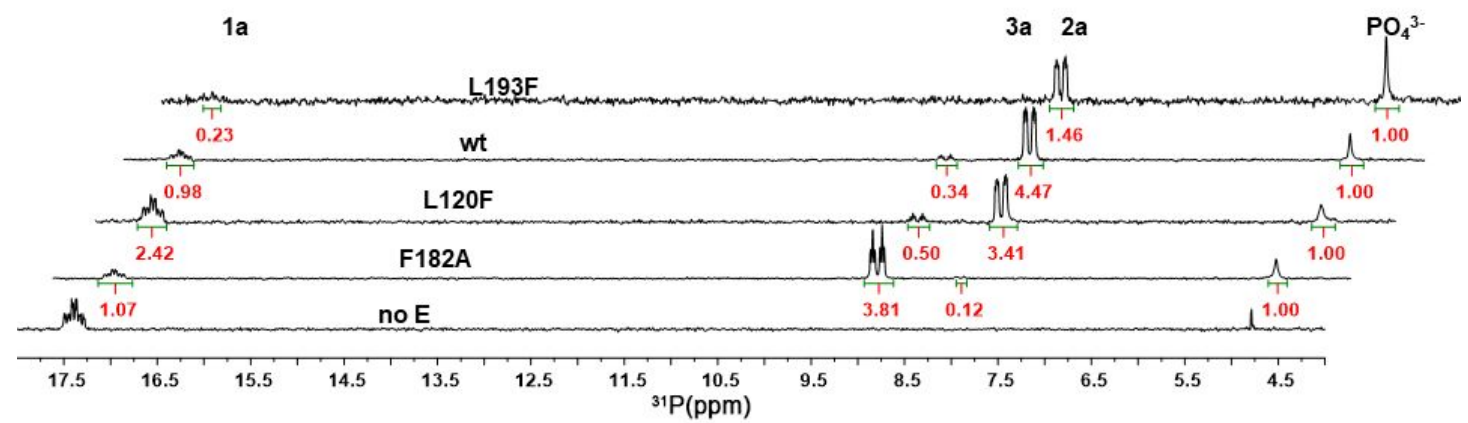

Figure S13. Selected ${ }^{31}$ P NMR spectra of reactions of (S)-3-F-2-HPP (1a) with HppE and variants. The multiplet at $\sim 17.4 \mathrm{ppm}$ is from $(S)$-3-F-2-HPP (1a). The two signals (doublet of doublet of doublets) at $\sim 9.1$ and $\sim 8.2 \mathrm{ppm}$ are from the trans and cis products, respectively. The single peak at $\sim 4.8 \mathrm{ppm}$ arises from the internal standard, $\mathrm{PO}_{4}{ }^{3-}$.

Table S8. ${ }^{19}$ F-NMR analysis of the reactions of $(S)-3-\mathrm{F}-2-\mathrm{HPP}$ with HppE and variants. Column headings are as described in the caption of Table S2.

\begin{tabular}{|c|c|c|c|c|c|c|c|c|c|c|}
\hline Entry & E & $\begin{array}{l}{[\mathrm{Fe}-\mathrm{E}]} \\
(\mathrm{mM})\end{array}$ & $\begin{array}{l}{[\mathrm{Sub}]} \\
(\mathrm{mM})\end{array}$ & $\mathrm{Sub} / \mathrm{IS}$ & trans/IS & cis/IS & $\begin{array}{l}{[\mathrm{Pdt}]} \\
(\mathrm{mM})\end{array}$ & TTN & $\operatorname{cis}(\%)$ & Conv $(\%)$ \\
\hline 1 & L193F & 0.8 & 3.6 & $3.66 \pm 0.89$ & $0.00 \pm 0.00$ & $2.76 \pm 0.13$ & $1.65 \pm 0.08$ & $2.1 \pm 0.1$ & $100 \pm 0.0$ & $44.9 \pm 8.2$ \\
\hline 2 & wt & 0.4 & 4 & $0.97 \pm 0.33$ & $0.33 \pm 0.06$ & $5.24 \pm 0.35$ & $3.34 \pm 0.25$ & $8.4 \pm 0.6$ & $94.2 \pm 0.8$ & $86.0 \pm 3.8$ \\
\hline 3 & L120F & 0.4 & 3.6 & $1.33 \pm 0.08$ & $0.51 \pm 0.06$ & $3.50 \pm 0.10$ & $2.40 \pm 0.09$ & $6.0 \pm 0.2$ & $87.4 \pm 0.9$ & $75.1 \pm 0.4$ \\
\hline 4 & F182A & 0.8 & 3 & $1.29 \pm 0.02$ & $3.85 \pm 0.05$ & $0.06 \pm 0.03$ & $2.35 \pm 0.35$ & $2.9 \pm 0.4$ & $1.4 \pm 0.7$ & $74.4 \pm 3.4$ \\
\hline
\end{tabular}

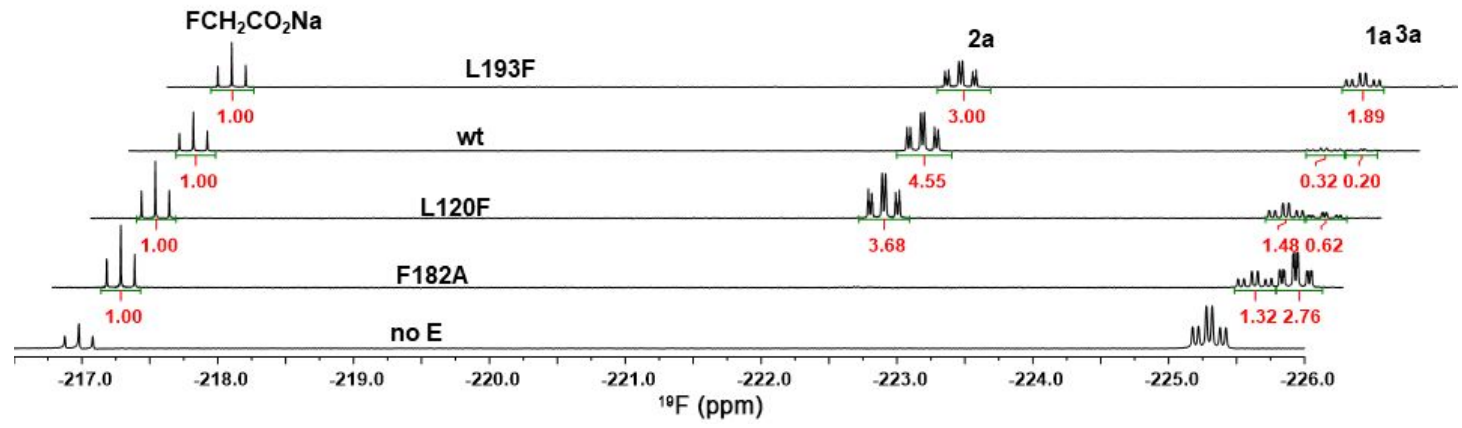

Figure S14. Selected ${ }^{19}$ F-NMR spectra of reactions of (S)-3-F-2-HPP (1a) with HppE and variants. The triplet at $\sim-217.0 \mathrm{ppm}$ is from the internal standard, $\mathrm{FCH}_{2} \mathrm{CO}_{2} \mathrm{Na}$. The triplets of doublets at $\sim-222.3$, $\sim-225.3$ and $\sim-225.6$ are from cis-3-F-Fos (2a), (S)-3-F-2-HPP (1a) and trans-3-F-Fos (3a), respectively. 
Table S9. ${ }^{31} \mathrm{P}$ NMR analysis of the reactions of $(S)-3-\mathrm{F}_{2}-2-\mathrm{HPP}$ with HppE and variants. Column headings are as described in the caption of Table S2.

\begin{tabular}{|c|c|c|c|c|c|c|c|c|c|c|}
\hline Entry & E & $\begin{array}{l}{[\mathrm{Fe}-\mathrm{E}]} \\
(\mathrm{mM})\end{array}$ & $\begin{array}{l}{[\mathrm{Sub}]} \\
(\mathrm{mM})\end{array}$ & Sub/IS & $\operatorname{trans} / \mathrm{IS}$ & cis/IS & $\begin{array}{l}{[\mathrm{Pdt}]} \\
(\mathrm{mM})\end{array}$ & TTN & $\operatorname{cis}(\%)$ & Conv( $(\%)$ \\
\hline 1 & L193F & 0.4 & 1.5 & $0.57 \pm 0.17$ & $0.00 \pm 0.00$ & $1.44 \pm 0.22$ & $0.86 \pm 0.16$ & $2.6 \pm 0.4$ & $100 \pm 0.0$ & $73.0 \pm 4.0$ \\
\hline 2 & wt & 0.7 & 3.6 & $0.32 \pm 0.00$ & $0.32 \pm 0.02$ & $4.21 \pm 0.20$ & $3.26 \pm 0.14$ & $4.7 \pm 0.2$ & $92.9 \pm 0.5$ & $93.4 \pm 0.2$ \\
\hline 3 & L120F & 0.4 & 4 & $3.36 \pm 0.55$ & $0.44 \pm 0.01$ & $1.98 \pm 0.12$ & $1.74 \pm 0.10$ & $4.3 \pm 0.2$ & $82.0 \pm 0.4$ & $42.6 \pm 5.7$ \\
\hline 4 & F182A & 0.8 & 3 & $0.43 \pm 0.05$ & $3.40 \pm 0.35$ & $0.09 \pm 0.00$ & $2.51 \pm 0.25$ & $3.1 \pm 0.5$ & $2.6 \pm 0.4$ & $89.0 \pm 0.8$ \\
\hline
\end{tabular}

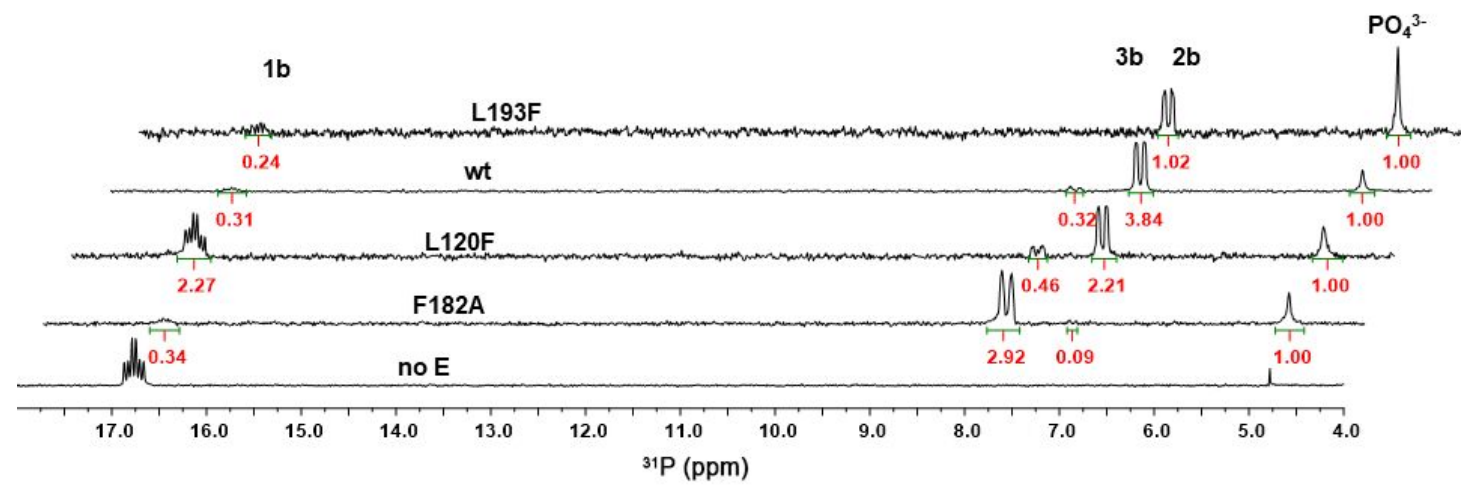

Figure S15. Selected ${ }^{31} \mathrm{P}-\mathrm{NMR}$ spectra of the reactions of $(S)-3-\mathrm{F}_{2}-2-\mathrm{HPP}(\mathbf{1 b})$ with HppE and variants.

The multiplets at $\sim 16.8, \sim 7.8$ and $\sim 7.1 \mathrm{ppm}$ are from $(S)-3-\mathrm{F}_{2}-2-\mathrm{HPP}(\mathbf{1 b})$, trans $-3-\mathrm{F}_{2}-\mathrm{Fos}(3 \mathrm{~b})$, and cis3-F 2 -Fos $(\mathbf{2 b})$, respectively. The single peak at $\sim 4.8 \mathrm{ppm}$ arises from the internal standard, $\mathrm{PO}_{4}{ }^{3-}$.

Table S10. ${ }^{19} \mathrm{~F}-\mathrm{NMR}$ analysis of the reactions of $(S)-3-\mathrm{F}_{2}-2-\mathrm{HPP}(\mathbf{1 b})$ with HppE and variants. Column headings are as described in the caption of Table S2.

\begin{tabular}{|c|c|c|c|c|c|c|c|c|c|c|}
\hline Entry & $\mathrm{E}$ & $\begin{array}{l}{[\mathrm{Fe}-\mathrm{E}]} \\
(\mathrm{mM})\end{array}$ & $\begin{array}{l}\text { [Sub] } \\
(\mathrm{mM})\end{array}$ & Sub/IS & trans/IS & cis/IS & $\begin{array}{l}{[\mathrm{Pdt}]} \\
(\mathrm{mM})\end{array}$ & TTN & $\operatorname{cis}(\%)$ & Conv( $(\%)$ \\
\hline 1 & L193F & 0.4 & 4 & $4.03 \pm 0.04$ & $0.00 \pm 0.00$ & $1.84 \pm 0.03$ & $1.33 \pm 0.03$ & $3.3 \pm 0.1$ & $99.8 \pm 0.2$ & $31.4 \pm 0.4$ \\
\hline 2 & wt & 0.7 & 3.6 & $0.20 \pm 0.10$ & $0.21 \pm 0.10$ & $4.64 \pm 0.07$ & $3.49 \pm 0.05$ & $5.0 \pm 0.1$ & $95.7 \pm 1.9$ & $93.4 \pm 0.2$ \\
\hline 3 & L120F & 0.4 & 4 & $3.89 \pm 0.01$ & $0.42 \pm 0.00$ & $1.87 \pm 0.02$ & $1.64 \pm 0.02$ & $4.1 \pm 0.0$ & $81.7 \pm 0.3$ & $37.0 \pm 0.3$ \\
\hline 4 & F182A & 0.8 & 3 & $0.93 \pm 0.45$ & $3.12 \pm 0.58$ & $0.06 \pm 0.03$ & $2.29 \pm 0.44$ & $2.9 \pm 0.5$ & $1.6 \pm 0.8$ & $76.7 \pm 11.9$ \\
\hline
\end{tabular}




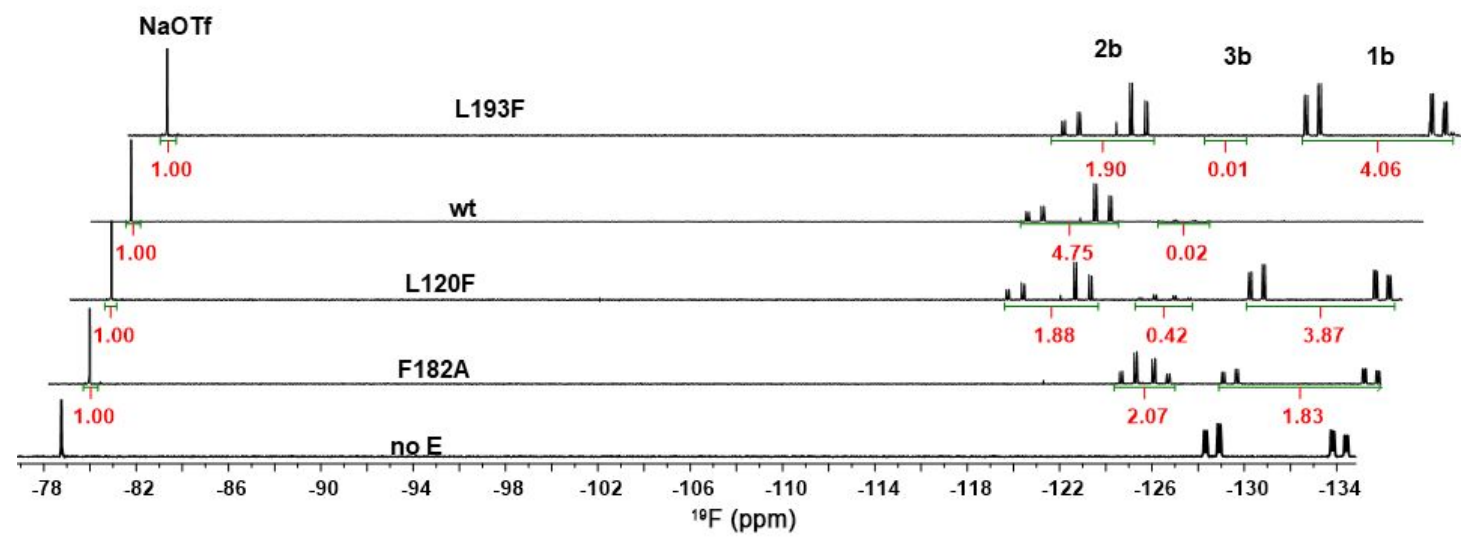

Figure S16. Selected ${ }^{19} \mathrm{~F}-\mathrm{NMR}$ spectra of the reactions of $(S)-3-\mathrm{F}_{2}-2-\mathrm{HPP}(\mathbf{1 b})$ with HppE and variants. The multiplets from $\sim-117.7 \mathrm{ppm}$ to $\sim-121.4 \mathrm{ppm}, \sim-123.6 \mathrm{ppm}$ to $\sim-125.7 \mathrm{ppm}$, and $\sim-128.3 \mathrm{ppm}$

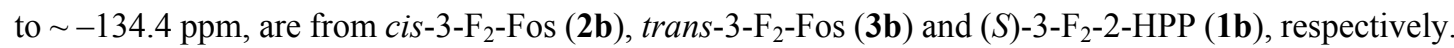
The single peak at $\sim-78.7 \mathrm{ppm}$ corresponds to the internal standard, NaOTf. 

into a mixture of the 2-ketone (4g), cis-epoxide (2g) and trans-epoxide (3g) products
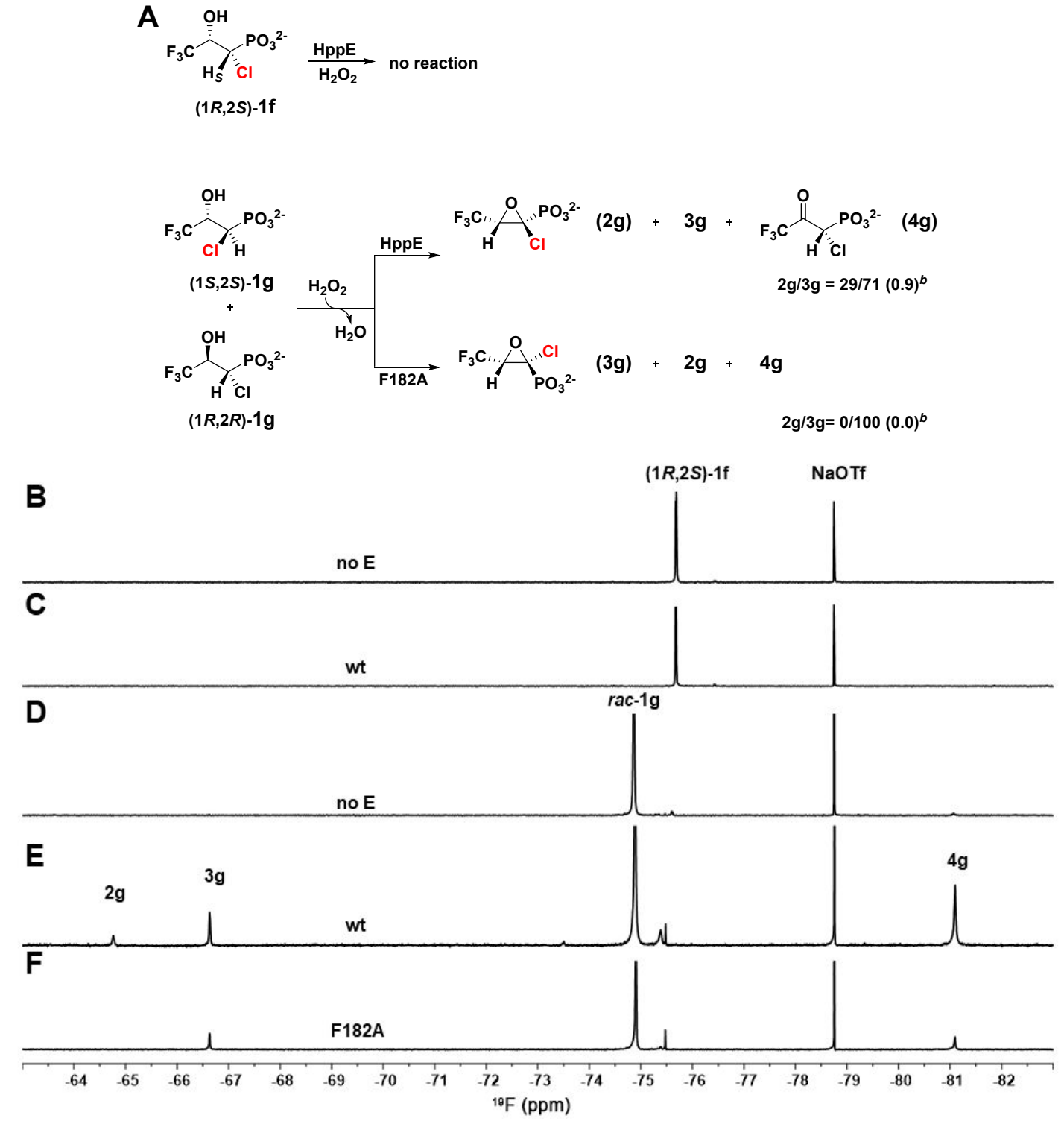

Figure S17. ${ }^{19} \mathrm{~F}-\mathrm{NMR}$ spectra of the reactions of $(1 R, 2 S)-1-\mathrm{Cl}-3-\mathrm{F}_{3}-\mathrm{HPP}[(1 R, 2 S)-\mathbf{1 f}]$ with $\mathrm{HppE}(\boldsymbol{B}-\boldsymbol{C})$, rac-anti-1-Cl-3-F - HPP (rac-1g) with HppE and the F182 variant (B-F). The doublets at -64.7 and -66.6 are from cis- and trans-1-Cl-3-F - Fos $(\mathbf{2 g}$ and $\mathbf{3 g})$, respectively. The peaks at $-74.9,-75.7,-78.7$, and 81.1 are from the substrates $[\mathrm{rac}-\mathbf{1 g}$ and $(1 R, 2 S)-\mathbf{1 f}]$, the internal standard NaOTf and 1-Cl-3-F $3-2-\mathrm{OPP}$ (4g), respectively. Reaction schemes depicting formation of the cis and trans epoxides (2g and $\mathbf{3 g}$, respectively) by the two proteins $(\boldsymbol{A})$. 
4.6 (1R,2S)-1-F-HPP (1h) is readily cyclized by HppE and its F182A variant.

A

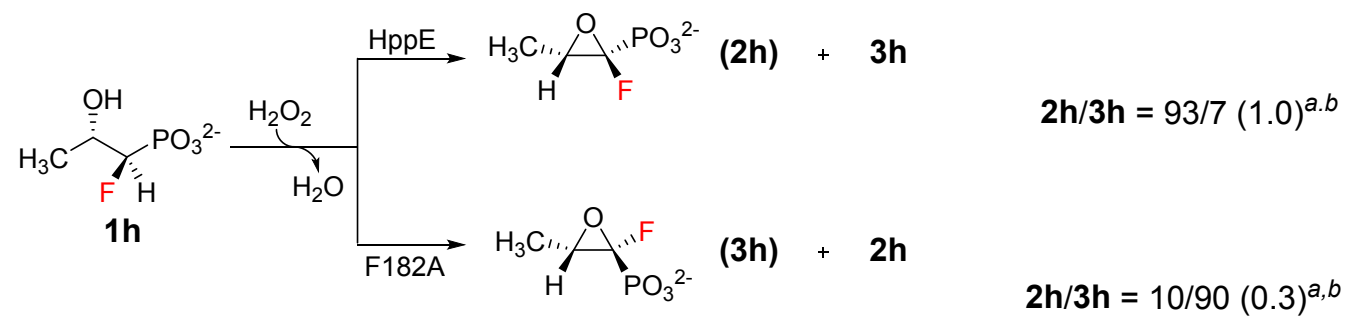

B Internal std. $+1 \mathrm{~h}+$ no enzyme

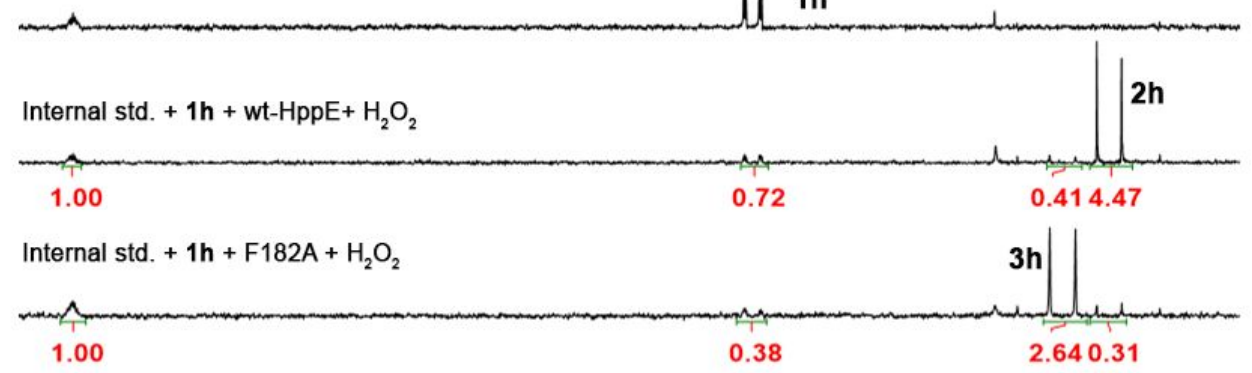

Internal std. + synthetic std. (4h)

4h

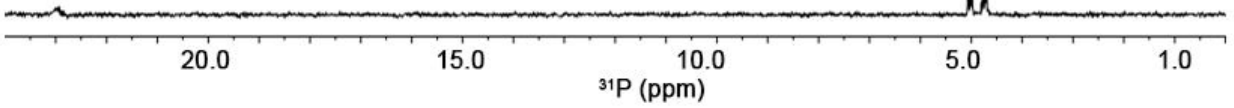

C

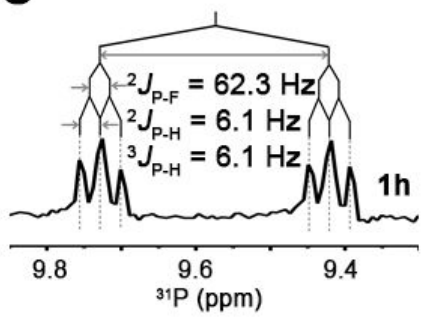

D $\quad{ }^{31} \mathrm{P}(\mathrm{ppm})$

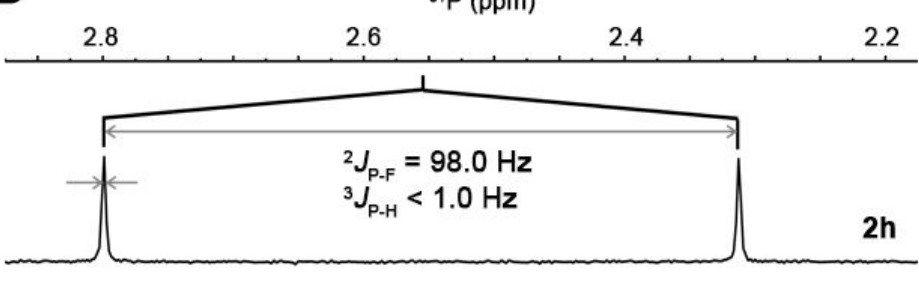

E
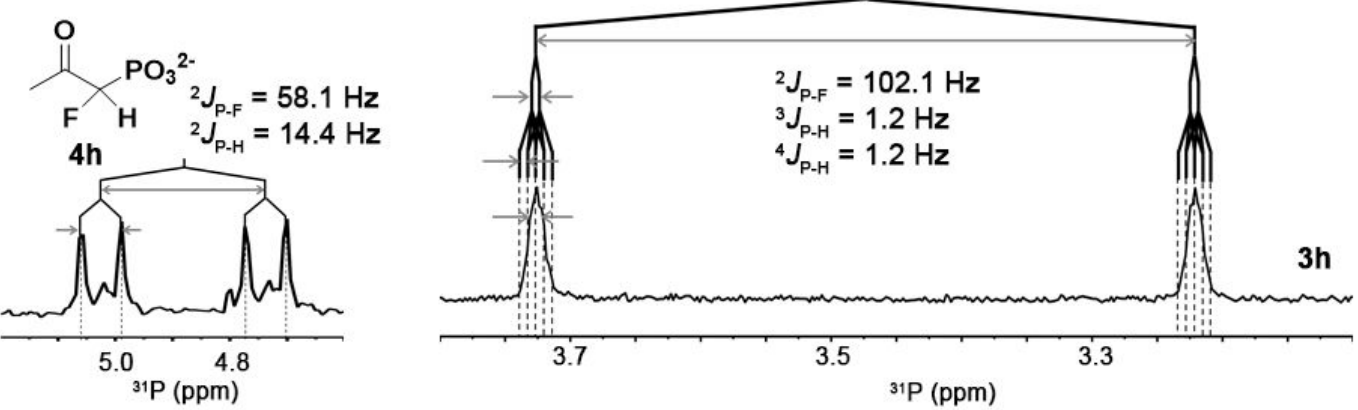


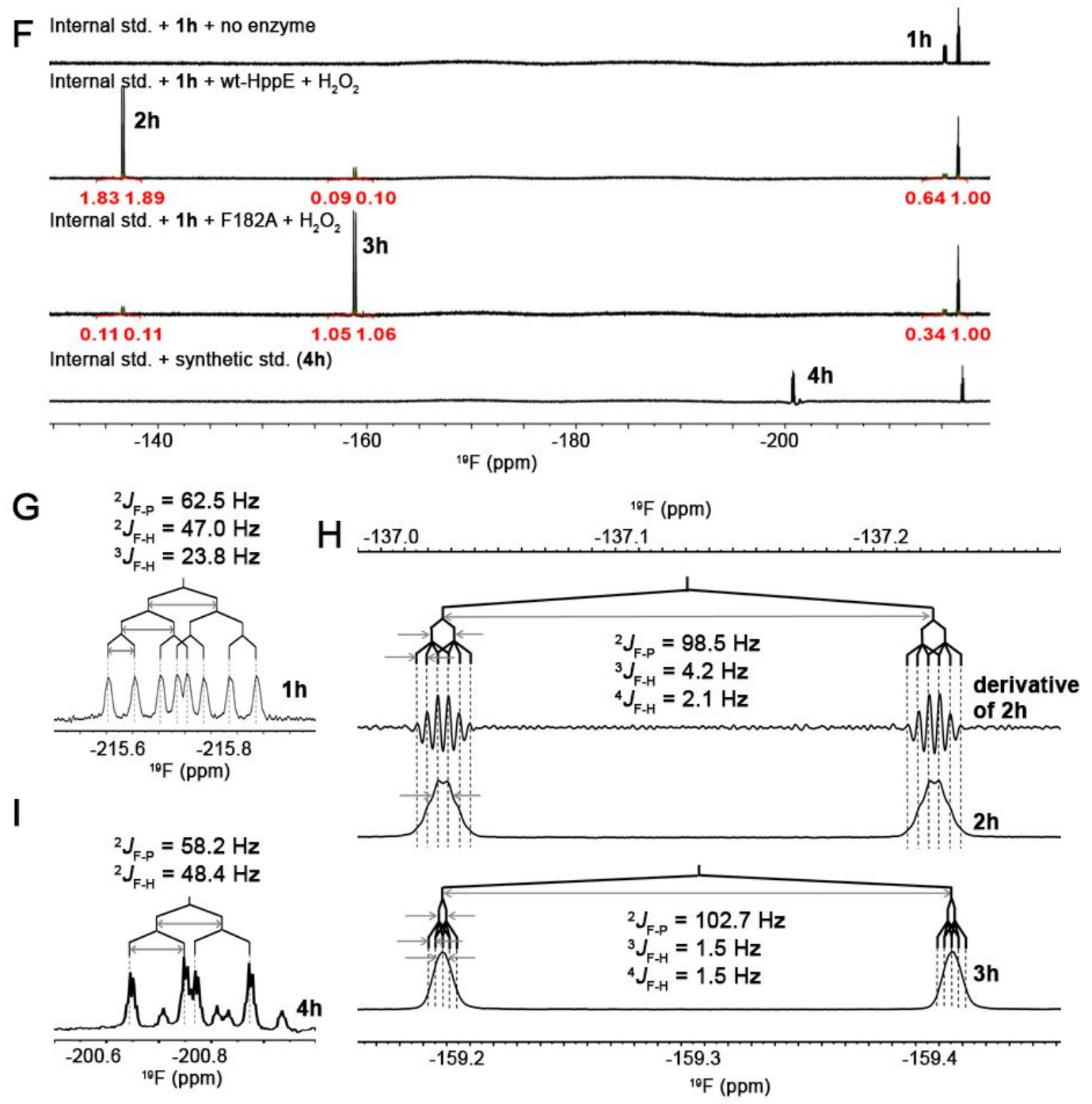

Figure S18. Analysis of the transformation of (1R,2S)-1-F-2-HPP (1h) by wild-type HppE and its F182A variant. (A) Reaction scheme depicting formation of the cis and trans epoxides ( $2 \mathbf{h}$ and $\mathbf{3 h}$, respectively) by the two proteins. (B) ${ }^{31} \mathrm{P}-\mathrm{NMR}$ spectra of the reactions of $\mathbf{1 h}$ with the wild-type and F182 proteins (second and third spectra from top) along with the spectra of the control reaction sample lacking any enzyme (top) and a sample of the synthetic 2-ketone standard (4h, bottom). (C-E) Blow-ups of the regions of the spectra in B showing: the ddd $\left({ }^{2} J_{\mathrm{P}-\mathrm{F}}=62.3,{ }^{2} J_{\mathrm{P}-\mathrm{H}}=6.1,{ }^{3} J_{\mathrm{P}-\mathrm{H}}=6.1 \mathrm{~Hz}\right)$ features of $1 \mathbf{h}$ at $\sim$ $9.6 \mathrm{ppm}(\mathbf{C})$; the doublet features of the cis $(\mathbf{2} \mathbf{h}, t o p)$ and trans $(\mathbf{3 h}$, bottom $)$ epoxide products at $\sim 2.6$ $\operatorname{ppm}\left({ }^{2} J_{\mathrm{P}-\mathrm{F}}=98.0,{ }^{3} J_{\mathrm{P}-\mathrm{H}}<1.0 \mathrm{~Hz}\right)$ and $\sim 3.5 \mathrm{ppm}\left({ }^{2} J_{\mathrm{P}-\mathrm{F}}=102.1 \mathrm{~Hz},{ }^{3} J_{\mathrm{P}-\mathrm{H}},{ }^{4} J_{\mathrm{P}-\mathrm{H}}=1.2 \mathrm{~Hz}\right)(\mathbf{D})$; and the dd $\left({ }^{2} J_{\mathrm{P}-\mathrm{F}}=58.1,{ }^{2} J_{\mathrm{P}-\mathrm{H}}=14.4 \mathrm{~Hz}\right)$ feature of the 2-ketone $(\mathbf{4 h})$ at $\sim 4.9 \mathrm{ppm}(\mathbf{E}) .(\mathbf{F}){ }^{19} \mathrm{~F}-\mathrm{NMR}$ spectra of the reactions of $\mathbf{1 h}$ with the wild-type and F182 proteins (second and third spectra from top) along with the spectra of the control reaction sample lacking any enzyme (top) and a sample of the synthetic 2-ketone 
standard (4h, bottom). (G-I) Blow-ups of the regions of the spectra in F showing: the doublet of doublet of quartets of the cis $(\mathbf{2} \mathbf{h}$, top $)$ and trans $(\mathbf{3 h}$, bottom $)$ epoxide products at $\sim-137.1 \mathrm{ppm}\left({ }^{2} J_{\mathrm{F}-\mathrm{P}}=98.5\right.$, $\left.{ }^{3} J_{\mathrm{F}-\mathrm{H}}=4.2,{ }^{4} J_{\mathrm{F}-\mathrm{H}}=2.1\right)$ and $\sim-159.3 \mathrm{ppm}\left({ }^{2} J_{\mathrm{F}-\mathrm{P}}=102.5,{ }^{3} J_{\mathrm{F}-\mathrm{H}},{ }^{4} J_{\mathrm{F}-\mathrm{H}}=1.5\right)(\mathbf{G})$; the dd feature $\left({ }^{2} J_{\mathrm{P}-\mathrm{F}}=58.2\right.$, $\left.{ }^{2} J_{\mathrm{F}-\mathrm{H}}=48.4 \mathrm{~Hz}\right)$ of the 2-ketone $(\mathbf{4 h})$ at $\sim-200.8 \mathrm{ppm}(\mathbf{H})$; and the ddd feature $\left({ }^{2} J_{\mathrm{F}-\mathrm{P}}=62.5,{ }^{2} J_{\mathrm{F}-\mathrm{H}}=47.0\right.$, $\left.{ }^{3} J_{\mathrm{F}-\mathrm{H}}=23.8 \mathrm{~Hz}\right)$ of $\mathbf{1 h}$ at $\sim-215.7 \mathrm{ppm}(\mathbf{I})$. The multiplet at $22.9 \mathrm{ppm}$ in the ${ }^{31} \mathrm{P}-\mathrm{NMR}$ spectrum and the triplet at $-217 \mathrm{ppm}$ in the ${ }^{19} \mathrm{~F}-\mathrm{NMR}$ spectrum arise from the internal standards, sodium propylphosphonate and sodium fluoroacetate, respectively. 


\section{Antimicrobial potencies of the (halogenated) cis- and trans-epoxide products}

A bioautography assay ${ }^{9-10}$ was used for the evaluation of antimicrobial potencies of the cis- and transepoxide products. As described above, $c i s-\mathrm{F}_{\mathrm{n}}-\mathrm{Fos}(\mathrm{n}=1-2)$ and trans $-\mathrm{F}_{\mathrm{n}}-\mathrm{Fos}(\mathrm{n}=1-3)$ compounds were produced by the L193F and F182A variants, respectively. The $c i s-\mathrm{F}_{3}$-Fos was produced by the L193F/L144F variant. The concentration of each compound was quantified by NMR. Each compound was then diluted or concentrated to $1.5 \mathrm{mM}$. Agar plates were spread with $\square 10^{7}$ colony-forming units (cfu) of Escherichia coli DH5a (K12), a strain that is susceptible to Fos, and 5-mm filter discs were placed on top. A $10 \mu \mathrm{L}$ aliquot of each $1.5 \mathrm{mM}$ stock was used to wet one of the filter discs. Fos (1.5 $\mathrm{mM})$ was used as the positive control, while the relevant substrate $(1.5 \mathrm{mM})$ served as the negative control. The discs were subsequently incubated overnight at $37{ }^{\circ} \mathrm{C}$. The antimicrobial potencies of the Fos analogs were normalized by comparing the zones of inhibition of the product group and positive control (Figure S20, 21). Each assay was performed in triplicate. The error bars correspond to the standard errors from the mean values of the three experiments. Experiments with $10 \mu \mathrm{L}$ of $0.15,0.375$, $0.75,1.125,1.5$ and $2.0 \mathrm{mM}$ commercial Fos were used for quantification of the zone of inhibition (Figure S19). 


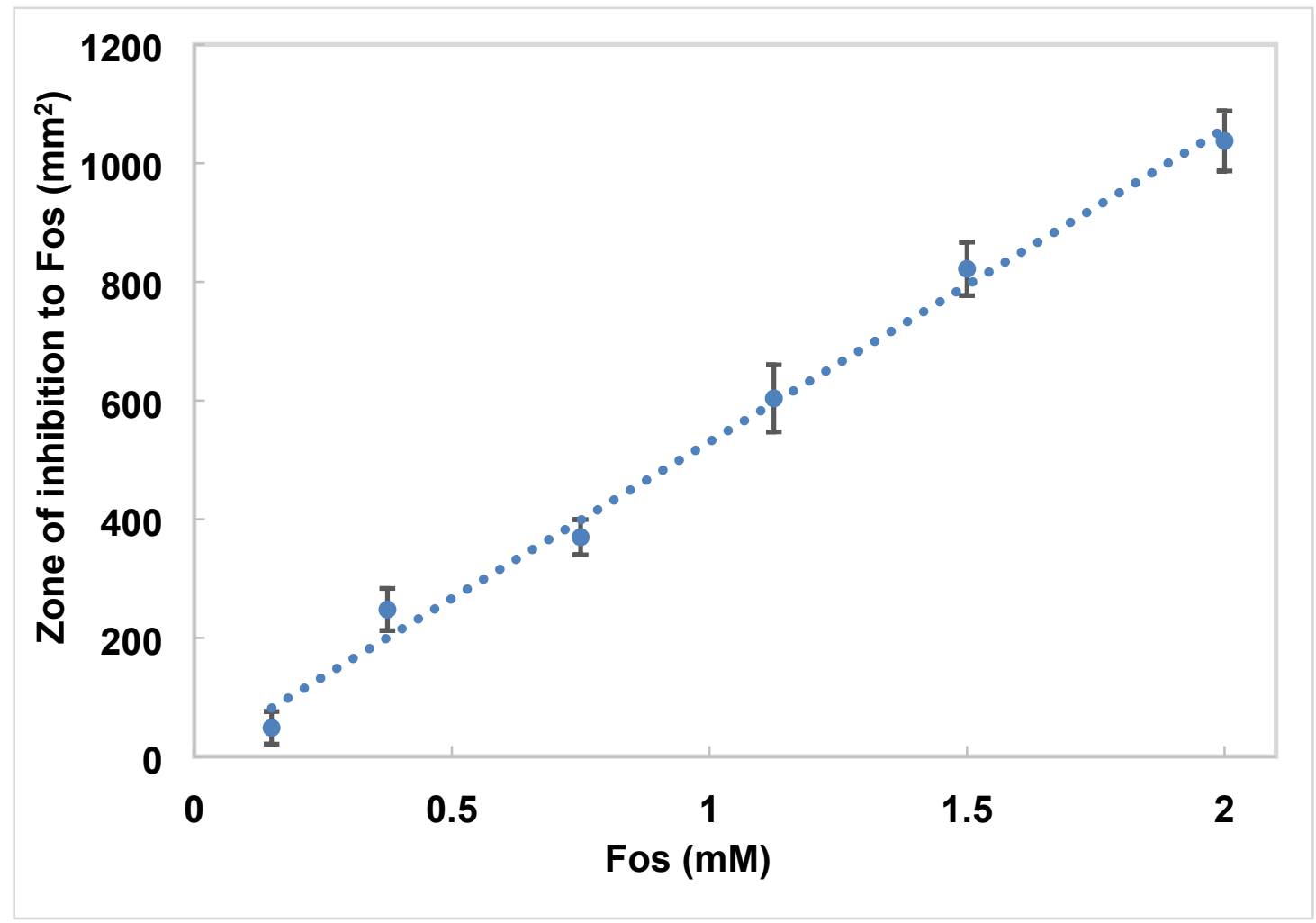

Figure S19. Standard curve relating area of the zone of inhibition to [Fos] (commercial compound).

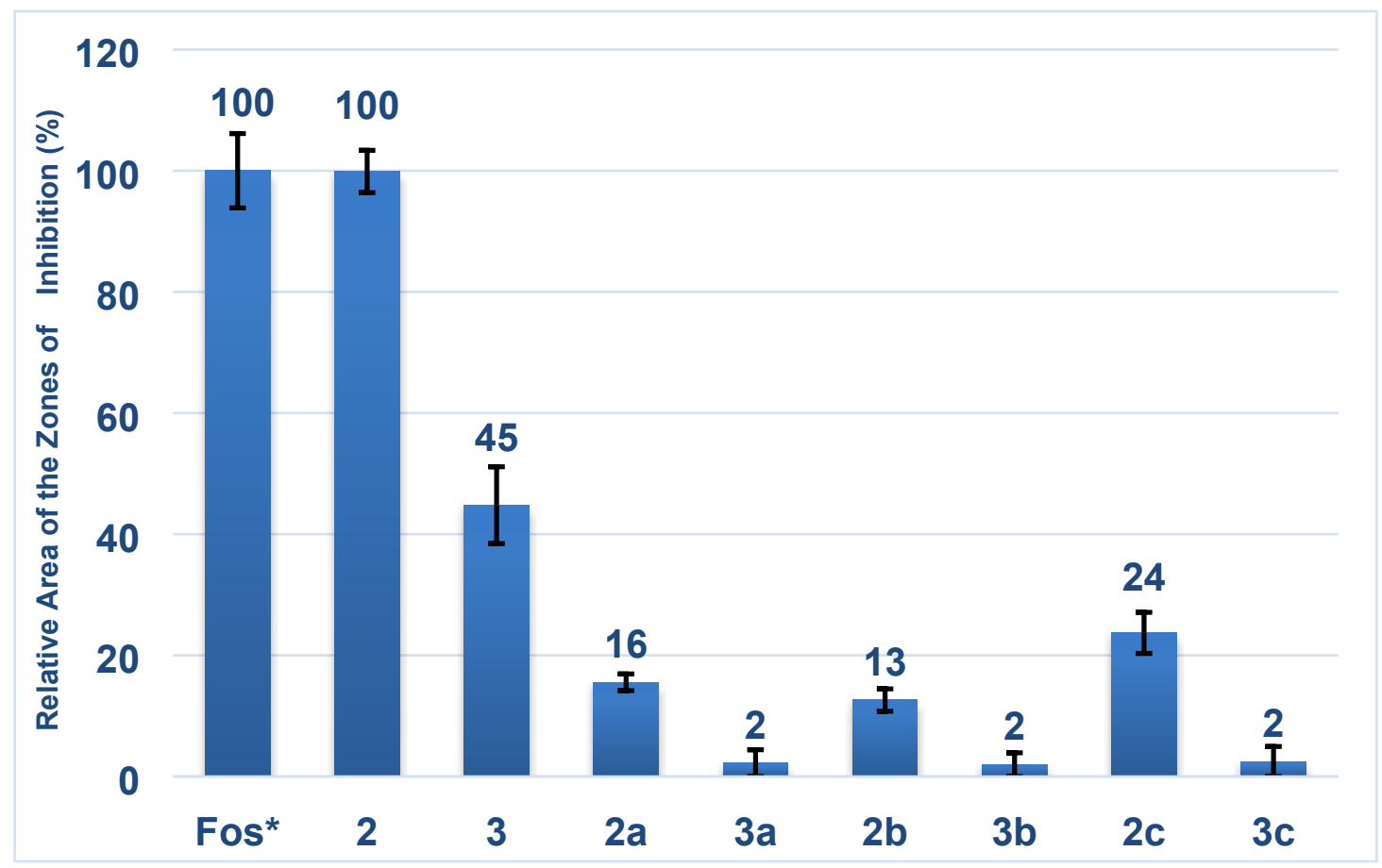

Figures S20. The relative areas of the zones of inhibition of cis/trans $-\mathrm{F}_{\mathrm{n}}-\mathrm{Fos}$ compounds relative to that generated by the same concentration of commercial Fos*. 


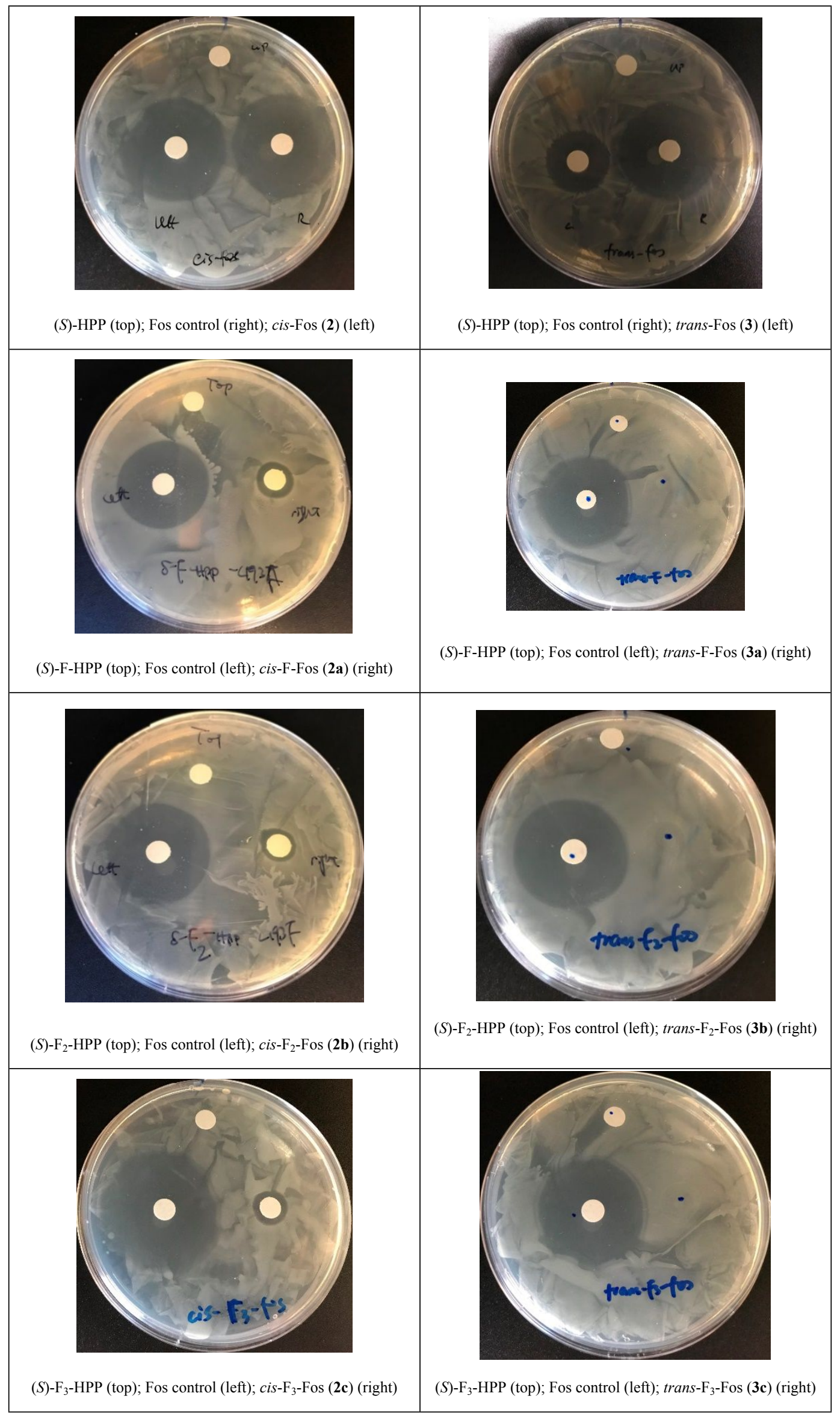

Figure S21. Representative agar plates for measuring the zones of inhibition. 


\section{Synthesis and characterization of the substrate and product standards.}

6.1 Synthesis of 1-d-2S-HPP diastereomers (1d and 1e) using adaptations of previously published methods. ${ }^{11-12}$

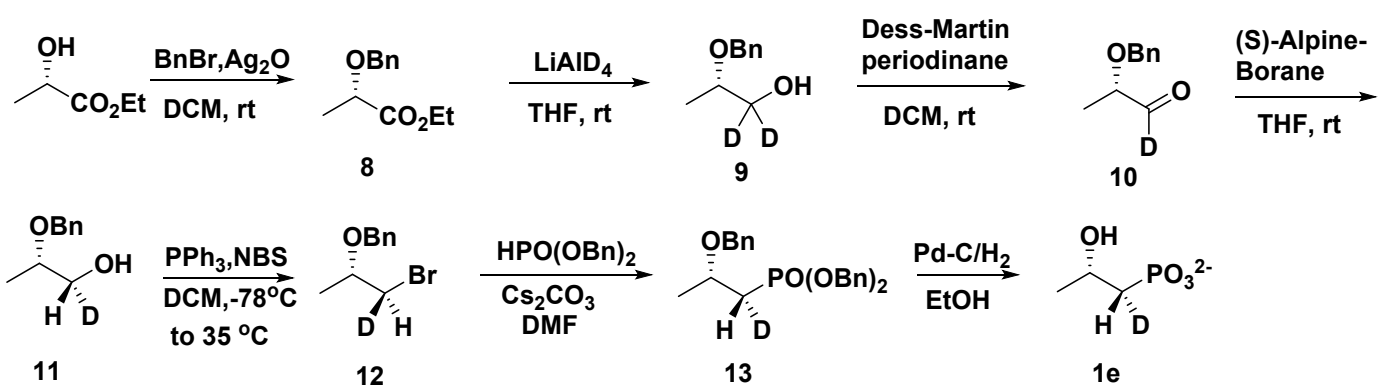

Ethyl (S)-2-(benzyloxy)propanoate (8). To a solution of (L)-ethyl lactate (10 g, $84.65 \mathrm{mmol})$ in dry ether $(100 \mathrm{~mL})$ were added $\mathrm{Ag}_{2} \mathrm{O}(29.42 \mathrm{~g}, 126.98 \mathrm{mmol})$ and $\mathrm{BnBr}(17.37 \mathrm{~g}, 101.58 \mathrm{mmol})$ at rt. The reaction was subsequently stirred for $16 \mathrm{~h}$ at $40^{\circ} \mathrm{C}$. After completion, it was filtered through a Celite pad and concentrated to obtain the crude compound. The material was purified via silica gel column chromatography (hexanes/ethyl acetate $=10 / 1)$ to afford compound $8(13 \mathrm{~g}, 74 \%)$ as a colorless oil. ${ }^{1} \mathrm{H}$ NMR (500 MHz, $\left.\mathrm{CDCl}_{3}\right) \delta 7.40-7.25(\mathrm{~m}, 5 \mathrm{H}), 4.70(\mathrm{~d}, J=11.6 \mathrm{~Hz}, 1 \mathrm{H}), 4.45(\mathrm{~d}, J=11.6 \mathrm{~Hz}, 1 \mathrm{H})$, $4.26-4.16(\mathrm{~m}, 2 \mathrm{H}), 4.05(\mathrm{q}, J=6.8 \mathrm{~Hz}, 1 \mathrm{H}), 1.44(\mathrm{~d}, J=6.9 \mathrm{~Hz}, 3 \mathrm{H}), 1.29(\mathrm{t}, J=7.1 \mathrm{~Hz}, 3 \mathrm{H})$.

(S)-2-(benzyloxy)propan-1,1-d $\boldsymbol{d}_{\mathbf{2}} \mathbf{- 1 - o l}$ (9). Into a mixture of $\mathrm{LiAlD}_{4}(1.13 \mathrm{~g}, 26.89 \mathrm{mmol})$ suspended in anhydrous THF (30 mL) was dripped a solution of ethyl $(S)$-2-(benzyloxy)propanoate (7 g, $33.61 \mathrm{mmol})$ in THF (30 mL) at rt. The reaction was then stirred for $1 \mathrm{~h}$. After complete consumption of the substrate, water was dripped in to quench the reaction until no bubbles were generated. The mixture was subsequently filtered through a Celite pad and concentrated before purification by chromatography $($ hexanes/ethyl acetate $=1 / 1)$ to afford $9(4 \mathrm{~g}, 72 \%)$ as a colorless oil. ${ }^{1} \mathrm{H} \mathrm{NMR}\left(500 \mathrm{MHz}, \mathrm{CDCl}_{3}\right) \delta 7.41$ $-7.27(\mathrm{~m}, 5 \mathrm{H}), 4.65(\mathrm{~d}, J=11.6 \mathrm{~Hz}, 1 \mathrm{H}), 4.49(\mathrm{~d}, J=11.6 \mathrm{~Hz}, 1 \mathrm{H}), 3.67(\mathrm{q}, J=6.3 \mathrm{~Hz}, 1 \mathrm{H}), 2.28(\mathrm{~s}$, $1 \mathrm{H}), 1.18(\mathrm{~d}, J=6.3 \mathrm{~Hz}, 3 \mathrm{H})$.

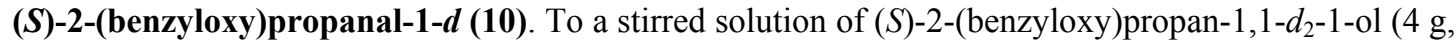
$23.78 \mathrm{mmol}$ ) in DCM was added Dess martin periodinane (15.13 $\mathrm{g}, 35.66 \mathrm{mmol})$, and the reaction was stirred at rt for 3 hours. After completion, the reaction was washed thoroughly with saturated aqueous sodium thiosulfate, saturated aqueous sodium bicarbonate and brine. The organic layer was dried over 
anhydrous sodium sulfate and concentrated in vacuo, and the resulting residue was used in the next step without further purification.

(1S,2R)-2-(benzyloxy)propan-1-d-1-ol (11). To a stirred solution of $\mathbf{1 0}$ (1.4 g, $8.47 \mathrm{mmol})$ in THF (30 $\mathrm{mL})$ was added $(S)$-Alpine-Borane $(25.4 \mathrm{~mL}, 12.71 \mathrm{mmol}, 0.5 \mathrm{M}$ solution in THF), and the resulting reaction mixture was stirred at $\mathrm{rt}$ overnight. Acetaldehyde $(1.44 \mathrm{~mL}, 25.42 \mathrm{mmol})$ and ethanolamine (1.22 $\mathrm{mL}, 20.34 \mathrm{mmol})$ were subsequently added to quench the reaction. The resulting mixture was stirred at $\mathrm{rt}$ for $30 \mathrm{~min}$ and then diluted with ethyl acetate $(150 \mathrm{~mL})$. The organic layer was then washed thoroughly with $1 \mathrm{M} \mathrm{HCl}$, saturated aqueous sodium bicarbonate and brine before being dried over anhydrous sodium sulfate and concentrated in vacuo. The resulting residue was purified by silica gel chromatography (hexanes/ethyl acetate $=1 / 1$ ), giving $1.2 \mathrm{~g}$ of the alcohol, 11, as a colorless oil with a yield of $85 \%$. ${ }^{1} \mathrm{H}$ NMR $\left(500 \mathrm{MHz}, \mathrm{CDCl}_{3}\right) \delta 7.37-7.29(\mathrm{~m}, 5 \mathrm{H}), 4.65(\mathrm{~d}, J=11.6 \mathrm{~Hz}, 1 \mathrm{H}), 4.50(\mathrm{~d}, J=$ $11.6 \mathrm{~Hz}, 1 \mathrm{H}), 3.70-3.62(\mathrm{~m}, 1 \mathrm{H}), 3.58(\mathrm{br}, 1 \mathrm{H}), 2.44(\mathrm{br}, 1 \mathrm{H}), 1.18(\mathrm{~d}, J=6.2 \mathrm{~Hz}, 3 \mathrm{H}) .{ }^{13} \mathrm{C} \mathrm{NMR}(126$ $\left.\mathrm{MHz}, \mathrm{CDCl}_{3}\right) \delta 138.50,128.48,127.77,127.72,75.55,70.82,65.92(\mathrm{t}, J=21.78 \mathrm{~Hz}), 15.93$.

((((1S,2S)-1-bromopropan-2-yl-1-d)oxy)methyl)benzene (12). Into a solution of $N$-bromosuccinimide $(1.53 \mathrm{~g}, 8.61 \mathrm{mmol})$ in DCM $(10 \mathrm{~mL})$ was dripped a solution of triphenyl phosphine $(2.26 \mathrm{~g}, 8.61 \mathrm{mmol})$ in DCM $(15 \mathrm{~mL})$ at $-78^{\circ} \mathrm{C}$ in the dark. The reaction was stirred at the same temperature for $10 \mathrm{~min}$, while a solution of $11(1.2 \mathrm{~g}, 7.18 \mathrm{mmol})$ in DCM $(9 \mathrm{~mL})$ was dripped in. Following removal of the cooling bath, the reaction was first stirred first at $\mathrm{rt}$ for $1 \mathrm{~h}$ and subsequently at $35^{\circ} \mathrm{C}$ for an additional $30 \mathrm{~min}$. The mixture was subsequently concentered in vacuo and purified by silica gel chromatography (hexanes/DCM = 1/1) to afford the bromide, $12(1.35 \mathrm{~g}, 82 \%) .{ }^{1} \mathrm{H}$ NMR $\left(500 \mathrm{MHz}, \mathrm{CDCl}_{3}\right) \delta 7.49-7.28$ (m, 5H), $4.61(\mathrm{br}, 2 \mathrm{H}), 3.79-3.74(\mathrm{~m}, 1 \mathrm{H}), 3.48-3.46(\mathrm{~m}, 1 \mathrm{H}), 1.34(\mathrm{~d}, J=6.2 \mathrm{~Hz}, 3 \mathrm{H}) .{ }^{13} \mathrm{C} \mathrm{NMR}(126$ $\left.\mathrm{MHz}, \mathrm{CDCl}_{3}\right) \delta 138.19,138.18,128.49,127.79,127.76,74.14,71.13,36.33(\mathrm{t}, J=23.11 \mathrm{~Hz}), 18.95$.

Dibenzyl ((1R,2S)-2-(benzyloxy)propyl-1-d)phosphonate (13). To a stirred solution of dibenzyl phosphonate $(0.957 \mathrm{~g}, 3.65 \mathrm{mmol})$ and $12(0.7 \mathrm{~g}, 3.04 \mathrm{mmol})$ in DMF $(20 \mathrm{~mL})$ was added cesium carbonate $(1.98 \mathrm{~g}, 6.08 \mathrm{mmol})$. The resulting suspension was the stirred at $\mathrm{rt}$ for $5 \mathrm{~h}$ before being quenched by addition of water $(100 \mathrm{~mL})$. The reaction mixture was subsequently extracted with EtOAc $(100 \mathrm{~mL} \times 3)$, the organic phase was concentrated in vacuo, and the resulting residue was purified by 
silica gel chromatography (hexanes/ethyl acetate $=1 / 1)$ to afford $\mathbf{1 3}(0.8 \mathrm{~g}, 64 \%)$ as a colorless oil. ${ }^{1} \mathrm{H}$ NMR (500 MHz, $\left.\mathrm{CDCl}_{3}\right) \delta 7.41-7.24(\mathrm{~m}, 15 \mathrm{H}), 5.11-4.90(\mathrm{~m}, 4 \mathrm{H}), 4.53(\mathrm{~d}, J=11.4 \mathrm{~Hz}, 1 \mathrm{H}), 4.46$ $(\mathrm{d}, J=11.4 \mathrm{~Hz}, 1 \mathrm{H}), 4.00-3.90(\mathrm{~m}, 1 \mathrm{H}), 1.99(\mathrm{dd}, J=18.2,6.7 \mathrm{~Hz}, 1 \mathrm{H}), 1.34(\mathrm{~d}, J=6.1 \mathrm{~Hz}, 3 \mathrm{H}) .{ }^{31} \mathrm{P}$ $\operatorname{NMR}\left(202 \mathrm{MHz}, \mathrm{CDCl}_{3}\right) \delta 29.81$.

((1R,2S)-2-hydroxypropyl-1-d)phosphonate (1e). Compound 13 (440 mg, $1.07 \mathrm{mmol})$ and $\mathrm{Pd} / \mathrm{C}(50$ $\mathrm{mg}, 10 \%$ palladium on carbon) were suspended in ethanol $(30 \mathrm{~mL})$ and stirred under a hydrogen atmosphere overnight. After completion, the $\mathrm{Pd} / \mathrm{C}$ was removed via filtration through a Celite pad. Sodium hydroxide ( $213 \mu \mathrm{L}$ of $10 \mathrm{M}$ in water, $2.13 \mathrm{mmol}$ ) was then added to the filtrate. The resulting mixture was stirred at $\mathrm{rt}$ for $30 \mathrm{~min}$ and dried to afford the product (150 mg, 76\%). ${ }^{1} \mathrm{H} \mathrm{NMR}(500 \mathrm{MHz}$, $\left.\mathrm{D}_{2} \mathrm{O}\right) \delta 4.08(\mathrm{~m}, J=6.6 \mathrm{~Hz}, 1 \mathrm{H}), 1.75(\mathrm{dd}, J=17.4,7.2 \mathrm{~Hz}, 1 \mathrm{H}), 1.25(\mathrm{~d}, J=6.2 \mathrm{~Hz}, 3 \mathrm{H})$ (Figure S2). ${ }^{13} \mathrm{C}$ NMR (126 MHz, $\left.\mathrm{D}_{2} \mathrm{O}\right) \delta 64.31,37.14$ (dt, $\left.J=129.0,19.0 \mathrm{~Hz}\right), 23.03$ (d, $\left.J=8.3 \mathrm{~Hz}\right)$. HRMS (ESI): calcd for $\mathrm{C}_{3} \mathrm{H}_{7} \mathrm{DO}_{4} \mathrm{P}\left(\mathrm{M}-\mathrm{H}^{-}\right)$140.0228, found 140.0234 .

((1S,2S)-2-hydroxypropyl-1-d)phosphonate (1d) was synthesized following the same procedure except using $(R)$-alpine borane instead of the $(S)$ enatntiomer. ${ }^{1} \mathrm{H}$ NMR $\left(500 \mathrm{MHz}, \mathrm{D}_{2} \mathrm{O}\right) \delta 4.14-4.07$ (m, 1H), $1.86(\mathrm{dd}, J=18.0,6.1 \mathrm{~Hz}, 1 \mathrm{H}), 1.27(\mathrm{~d}, J=6.2 \mathrm{~Hz}, 3 \mathrm{H})$ (Figure S2). ${ }^{13} \mathrm{C}$ NMR $(126 \mathrm{MHz}$, $\left.\mathrm{D}_{2} \mathrm{O}\right) \delta 64.33,37.15\left(\mathrm{dt}, J=129.0,18.8 \mathrm{~Hz}\right.$ ), $23.03(\mathrm{~d}, J=8.4 \mathrm{~Hz})$. HRMS (ESI): calcd for $\mathrm{C}_{3} \mathrm{H}_{7} \mathrm{DO}_{4} \mathrm{P}$ (M-H-) 140.0228, found 140.0234.

6.2 Synthesis of (S)-3-F-2-HPP (1a) and (S)-3,3-F $\mathrm{F}_{2}-2-\mathrm{HPP}(1 \mathrm{~b})$.
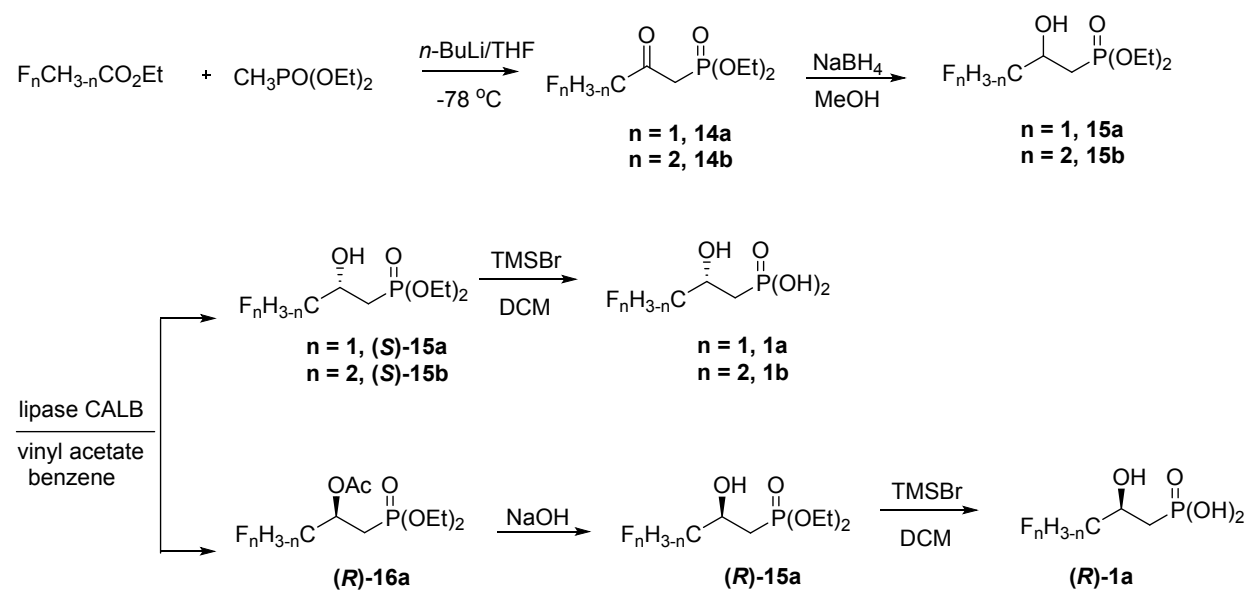

Diethyl (3-fluoro-2-oxopropyl)phosphonate (14a). To a mixture of THF (30 mL) and diethyl 
methylphosphonate $(5 \mathrm{~g}, 32.87 \mathrm{mmol})$ cooled to $-78^{\circ} \mathrm{C}$ was gradually added $n$-BuLi $(19 \mathrm{~mL}, 49.30 \mathrm{mmol}$, 2.6 $\mathrm{M}$ in $n$-hexane) and ethyl 2-fluoroacetate $(3.49 \mathrm{~g}, 32.87 \mathrm{mmol})$. The reaction temperature was kept under $-65^{\circ} \mathrm{C}$ while the mixture was then stirred for an additional $3 \mathrm{~h}$, before quenching via addition of 1 $N \mathrm{HCl}(30 \mathrm{~mL})$. The mixture was extracted with ether, washed with aqueous $\mathrm{NaHCO}_{3}$, and dried over $\mathrm{Na}_{2} \mathrm{SO}_{4}$. Subsequent concentration under reduced pressure yielded an oily residue that was purified by flash chromatography on silica gel with hexanes/ethyl acetate (1/1) as the eluting solvent to give 14a (3.8 g, 54\%). ${ }^{1} \mathrm{H}$ NMR (360 MHz, $\left.\mathrm{CDCl}_{3}\right) \delta 4.91(\mathrm{~d}, J=47.3 \mathrm{~Hz}, 2 \mathrm{H}), 4.15(\mathrm{p}, J=7.6,7.1 \mathrm{~Hz}, 4 \mathrm{H}), 3.19(\mathrm{dd}$, $J=22.9,3.5 \mathrm{~Hz}, 2 \mathrm{H}), 1.33(\mathrm{t}, J=7.0 \mathrm{~Hz}, 6 \mathrm{H}) .{ }^{31} \mathrm{P} \mathrm{NMR}\left(146 \mathrm{MHz}, \mathrm{CDCl}_{3}\right) \delta 18.04 .{ }^{19} \mathrm{~F}$ NMR $(282$ $\left.\mathrm{MHz}, \mathrm{CDCl}_{3}\right) \delta-225.01(\mathrm{t}, J=47.2 \mathrm{~Hz})$.

Diethyl (3-fluoro-2-hydroxypropyl)phosphonate (rac-15a). To a solution of 14a (2 g, $9.43 \mathrm{mmol})$ in methanol $(20 \mathrm{~mL})$, which was maintained at $\sim 0-5^{\circ} \mathrm{C}$ via the use of an ice bath, was gradually added $\mathrm{NaBH}_{4}(1.07 \mathrm{~g}, 28.28 \mathrm{mmol})$. After $10 \mathrm{~min}$, the reaction mixture was quenched by addition of saturated $\mathrm{NH}_{4} \mathrm{Cl}(30 \mathrm{~mL})$ and extracted by DCM $(3 \times 50 \mathrm{~mL})$. The organic layer was subsequently concentrated and purified by chromatography to afford 15a as a colorless oil (1.90 g, 94\%). ${ }^{1} \mathrm{H}$ NMR (360 MHz, $\left.\mathrm{CDCl}_{3}\right) \delta 4.39(\mathrm{dd}, J=47.1,4.8 \mathrm{~Hz}, 2 \mathrm{H}), 4.30-3.96(\mathrm{~m}, 5 \mathrm{H}), 3.03(\mathrm{br}, 1 \mathrm{H}), 2.15(\mathrm{dd}, J=17.9,5.9 \mathrm{~Hz}$, 2H), $1.33(\mathrm{t}, J=7.0 \mathrm{~Hz}, 6 \mathrm{H}) .{ }^{19} \mathrm{~F}$ NMR $\left(471 \mathrm{MHz}, \mathrm{CDCl}_{3}\right) \delta-228.67$ (tdd, $\left.J=47.1,17.5,2.9 \mathrm{~Hz}\right) .{ }^{31} \mathrm{P}$ NMR (146 MHz, $\left.\mathrm{CDCl}_{3}\right) \delta 29.03$

Diethyl (S)-(3-fluoro-2-hydroxypropyl)phosphonate $((S)-15 a)$ and (R)-1-(diethoxyphosphoryl)-3fluoropropan-2-yl acetate $((R)-16 a)$. Following published procedures, ${ }^{3}$ Candida antarctica: lipase B (Novozyme 435) (2.0 g) and vinyl acetate ( $5.2 \mathrm{~mL}, 46.69 \mathrm{mmol})$ were added to a solution of $\mathbf{1 5 a}$ $(1.0 \mathrm{~g}, 4.57 \mathrm{mmol})$ in $40 \mathrm{~mL}$ benzene. The reaction was then stirred at $\mathrm{rt}$, and the progress of the reaction was monitored by ${ }^{31} \mathrm{P}$ NMR spectroscopy. Once the reaction reached $\sim 50 \%$ conversion, the reaction mixture was subsequently filtered through a Celite pad. Concentration under reduced pressure yielded an oily residue that was purified and separated by silica gel chromatography with DCM/acetone $(4 / 1 \sim 1 / 1)$ as the eluting solvent to give a mixture of $(S)-\mathbf{1 5 a}(0.45 \mathrm{~g}, 45 \%)$ and $(R)$ 16a $(0.55 \mathrm{~g}, 46 \%)$ as a colorless oil.

(S)-15a. ${ }^{1} \mathrm{H}$ NMR $\left(500 \mathrm{MHz}, \mathrm{CDCl}_{3}\right) \delta 4.48-4.31(\mathrm{~m}, 2 \mathrm{H}), 4.29-4.03(\mathrm{~m}, 5 \mathrm{H}), 3.67$ (br, $\left.1 \mathrm{H}\right), 2.05-$ $1.97(\mathrm{~m}, 2 \mathrm{H}), 1.33(\mathrm{td}, J=7.0,1.6 \mathrm{~Hz}, 6 \mathrm{H}) .{ }^{31} \mathrm{P} \mathrm{NMR}\left(202 \mathrm{MHz}, \mathrm{CDCl}_{3}\right) \delta 28.98 .{ }^{19} \mathrm{~F} \mathrm{NMR}(471 \mathrm{MHz}$, 
$\left.\mathrm{CDCl}_{3}\right) \delta-228.86(\mathrm{tdd}, J=47.1,17.2,3.0 \mathrm{~Hz}) .{ }^{13} \mathrm{C} \mathrm{NMR}\left(125 \mathrm{MHz}, \mathrm{CDCl}_{3}\right) \delta 86.09(\mathrm{dd}, J=172.0,16.7$ Hz), $65.61(\mathrm{dd}, J=21.1,4.4 \mathrm{~Hz}), 62.25(\mathrm{dd}, J=14.8,6.5 \mathrm{~Hz}), 29.26(\mathrm{dd}, J=141.1,5.6 \mathrm{~Hz}), 16.51$ (dd, $J=6.0,3.0 \mathrm{~Hz}$ ). The e.e. of $(S)-\mathbf{1 5 a}$ was determined to be $99 \%$ (Figure S22).

(R)-16a. ${ }^{1} \mathrm{H}$ NMR $\left(500 \mathrm{MHz}, \mathrm{CDCl}_{3}\right) \delta 5.38-5.17(\mathrm{~m}, 1 \mathrm{H}), 4.54(\mathrm{dd}, J=47.4,4.9,3.3 \mathrm{~Hz}, 2 \mathrm{H}), 4.15-$ $4.06(\mathrm{~m}, 4 \mathrm{H}), 2.17(\mathrm{ddd}, J=19.2,6.9,3.6 \mathrm{~Hz}, 2 \mathrm{H}), 2.09(\mathrm{~s}, 3 \mathrm{H}), 1.33(\mathrm{t}, J=7.1 \mathrm{~Hz}, 6 \mathrm{H}) .{ }^{31} \mathrm{P}$ NMR $(202$ $\left.\mathrm{MHz}, \mathrm{CDCl}_{3}\right) \delta 25.29 .{ }^{19} \mathrm{~F} \mathrm{NMR}\left(471 \mathrm{MHz}, \mathrm{CDCl}_{3}\right) \delta-231.17(\mathrm{td}, J=47.1,22.4 \mathrm{~Hz}) .{ }^{13} \mathrm{C} \mathrm{NMR}(125$ $\left.\mathrm{MHz}, \mathrm{CDCl}_{3}\right) \delta 170.12,83.38(\mathrm{dd}, J=174.7,7.6 \mathrm{~Hz}), 67.88(\mathrm{~d}, J=19.9 \mathrm{~Hz}), 62.21(\mathrm{dd}, J=6.4,2.1 \mathrm{~Hz})$, $26.72(\mathrm{dd}, J=141.7,6.4 \mathrm{~Hz}), 21.11,16.50(\mathrm{~d}, J=6.1 \mathrm{~Hz})$

(R)-15a. A solution of $(R)-16 a(0.2 \mathrm{~g}, 0.78 \mathrm{mmol})$ in $\mathrm{NH}_{3} / \mathrm{MeOH}(2 \mathrm{M}, 7 \mathrm{~mL})$ was stirred for $48 \mathrm{~h}^{\text {at }} \mathrm{rt}^{13}$ The solvent was subsequently removed under reduced pressure, and the remaining residue was purified on silica gel $(\mathrm{DCM} /$ acetone $=1 / 1)$ to afford $(R)-\mathbf{1 5 a}$ as a colorless oil in $92 \%$ yield. The ${ }^{1} \mathrm{H},{ }^{31} \mathrm{P},{ }^{19} \mathrm{~F}$, and ${ }^{13} \mathrm{C}$ NMR spectra of $(R)$-15a are identical to those of $(S)$-15a. The e.e. of $(R)-\mathbf{1 5 a}$ was determined to be 92\% (Figure S22).

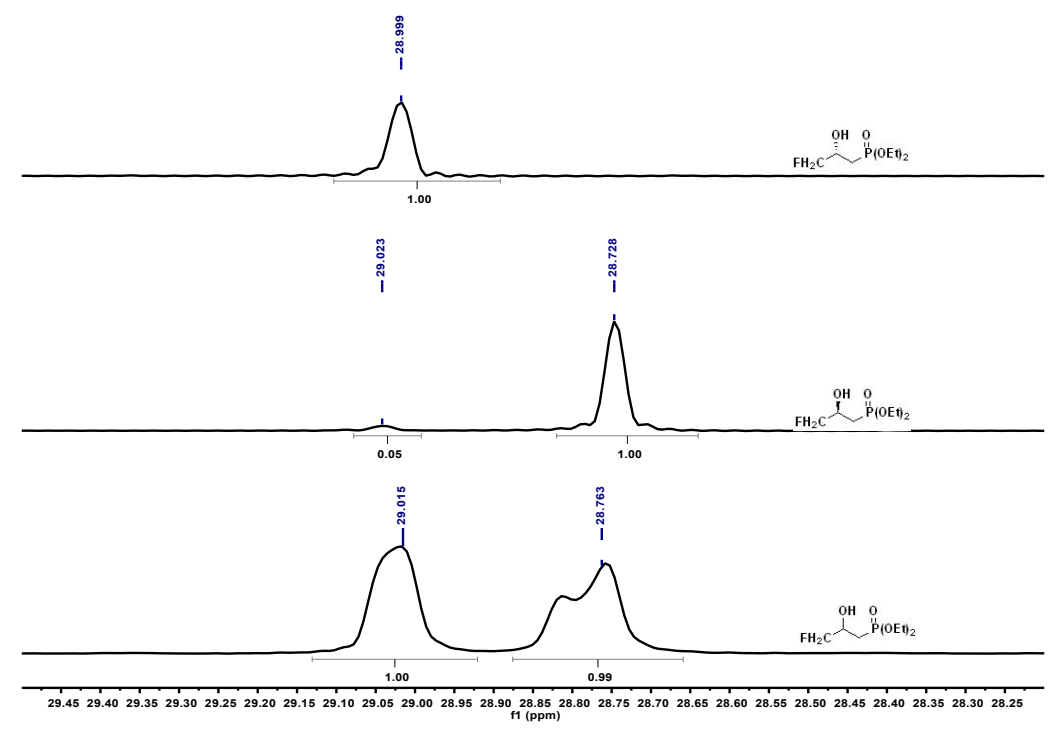

Figure S22. Determination of the e.e. of $(R)-\mathbf{1 5 a}(92 \%$, middle spectrum) and $(S)-\mathbf{1 5 a}(99 \%$, top spectrum) by ${ }^{31} \mathrm{P}$ NMR, utilizing quinine as a chiral solvating agent ${ }^{14-15}$. Each sample contained $50 \mathrm{mg}$ of quinine and $15 \mathrm{mg}$ of substrate dissolved in $0.6 \mathrm{~mL}$ of $\mathrm{CDCl}_{3}$.

(S)-(3-fluoro-2-hydroxypropyl)phosphonate (1a). $\operatorname{TMSBr}(0.71 \mathrm{~g}, 4.62 \mathrm{mmol})$ and allyl 
trimethylsilane $(0.27 \mathrm{~g}, 2.38 \mathrm{mmol})$ were added to a solution of $(S)-\mathbf{1 5 a}(0.3 \mathrm{mg}, 1.4 \mathrm{mmol})$ in $\mathrm{CH}_{2} \mathrm{Cl}_{2}(20 \mathrm{~mL})$ at $\mathrm{rt}$, and the solution was stirred overnight. The solvent was then removed under reduced pressure, and the resulting residue was resuspended in $\mathrm{CHCl}_{3}(20 \mathrm{~mL})$ and water $(20 \mathrm{~mL})$ before being neutralized with $\mathrm{NH}_{4} \mathrm{HCO}_{3}$. The aqueous layer was subsequently collected and lyophilized to afford $(S)-1 \mathrm{a}$ as a white solid $(0.18 \mathrm{~g}, 80 \%) .{ }^{1} \mathrm{H}$ NMR $\left(500 \mathrm{MHz}, \mathrm{D}_{2} \mathrm{O}\right) \delta 4.56$ (ddd, $J$ $=46.9,10.0,2.6 \mathrm{~Hz}, 1 \mathrm{H}), 4.40(\mathrm{ddd}, J=47.5,10.0,6.2 \mathrm{~Hz}, 1 \mathrm{H}), 4.23-4.12(\mathrm{~m}, 1 \mathrm{H}), 1.91-1.78(\mathrm{~m}$, 2H). ${ }^{31} \mathrm{P}$ NMR (202 MHz, $100 \mathrm{mM} \mathrm{NaOD}$ in $\left.\mathrm{D}_{2} \mathrm{O}\right) \delta 17.39(\mathrm{~m}, J=16.3,8.3,2.5 \mathrm{~Hz}) .{ }^{19} \mathrm{~F}$ NMR $(471$ MHz, $100 \mathrm{mM} \mathrm{NaOD}$ in $\left.\mathrm{D}_{2} \mathrm{O}\right) \delta-227.29(\mathrm{~m}, J=47.1,20.8,3.3 \mathrm{~Hz}) .{ }^{13} \mathrm{C}$ NMR $\left(126 \mathrm{MHz}, \mathrm{D}_{2} \mathrm{O}\right) \delta 86.76$ (dd, $J=167.2,10.5 \mathrm{~Hz}), 66.64(\mathrm{~d}, J=19.3 \mathrm{~Hz}), 30.77(\mathrm{dd}, J=131.4,7.1 \mathrm{~Hz})$. The ${ }^{1} \mathrm{H},{ }^{31} \mathrm{P},{ }^{19} \mathrm{~F}$, and ${ }^{13} \mathrm{C}$ NMR spectra of $(R)-\mathbf{1 a}$ were identical to those of $(S)-\mathbf{1 a}$. HRMS (ESI): calcd for $\mathrm{C}_{3} \mathrm{H}_{7} \mathrm{FO}_{4} \mathrm{P}\left(\mathrm{M}-\mathrm{H}^{-}\right)$ 157.0071, found 157.0076.

Compound $(S)-3,3-\mathrm{F}_{2}-2-\mathrm{HPP}(\mathbf{1 b})$ was prepared using the same procedure as for 1a, except that ethyl 2,2-difluoroacetate was used as the starting material. ${ }^{1} \mathrm{H}$ NMR data for intermediates and product are summarized below.

Diethyl (3,3-difluoro-2-oxopropyl)phosphonate (14b). ${ }^{1} \mathrm{H}$ NMR $\left(360 \mathrm{MHz}, \mathrm{CDCl}_{3}\right) \delta 5.88(\mathrm{t}, J=53.7$ $\mathrm{Hz}, 0.5 \mathrm{H}), 5.54(\mathrm{t}, J=55.8 \mathrm{~Hz}, 0.5 \mathrm{H}), 4.19-4.12(\mathrm{~m}, 4 \mathrm{H}), 3.32$ (d, $J=22.6 \mathrm{~Hz}, 1 \mathrm{H}), 2.21$ (d, $J=18.8$ $\mathrm{Hz}, 1 \mathrm{H}), 1.32(\mathrm{t}, J=7.0 \mathrm{~Hz}, 6 \mathrm{H}) .{ }^{19} \mathrm{~F} \mathrm{NMR}\left(282 \mathrm{MHz}, \mathrm{CDCl}_{3}\right) \delta-128.60(\mathrm{~d}, J=53.7 \mathrm{~Hz}),-134.23(\mathrm{dd}$, $J=56.0,6.9 \mathrm{~Hz}) .{ }^{31} \mathrm{P}$ NMR $\left(146 \mathrm{MHz}, \mathrm{CDCl}_{3}\right) \delta 27.76,17.37$.

Diethyl (3,3-difluoro-2-hydroxypropyl)phosphonate (rac-15b). ${ }^{1} \mathrm{H}$ NMR (300 MHz, $\left.\mathrm{CDCl}_{3}\right) \delta 5.75$ (t, $J=55.9 \mathrm{~Hz}, 1 \mathrm{H}), 4.19-4.08(\mathrm{~m}, 5 \mathrm{H}), 3.67(\mathrm{br}, 1 \mathrm{H}), 2.14-1.95(\mathrm{~m}, 2 \mathrm{H}), 1.33(\mathrm{t}, J=7.1 \mathrm{~Hz}, 6 \mathrm{H}) .{ }^{31} \mathrm{P}$ NMR $\left(146 \mathrm{MHz}, \mathrm{CDCl}_{3}\right) \delta 28.73 .{ }^{19} \mathrm{~F} \mathrm{NMR}\left(282 \mathrm{MHz}, \mathrm{CDCl}_{3}\right) \delta-128.58(\mathrm{ddd}, J=285.0,55.6,8.5 \mathrm{~Hz})$, -133.37 (ddd, $J=285.1,56.5,13.4 \mathrm{~Hz}$ ).

Diethyl (S)-(3,3-difluoro-2-hydroxypropyl)phosphonate ((S)-15b). Following the same procedure for the kinetic resolution of $(S)$-15a, $(S)$-15b was obtained in 45\% yield and $99 \%$ e.e. (Figure S23). 


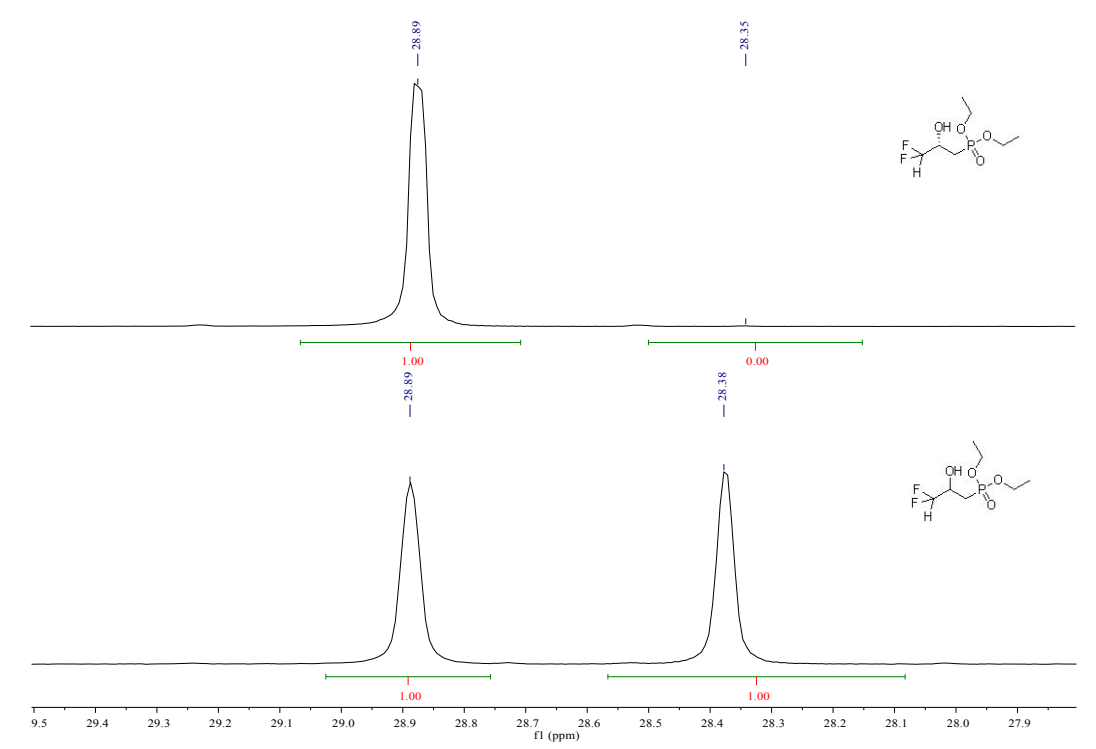

Figure S23. Determination of the e.e. of $(S)-\mathbf{1 5 b}\left(99 \%\right.$, top spectrum) by ${ }^{31} \mathrm{P}$ NMR with quinine as a chiral solvating agent. ${ }^{14-15}$ Each sample contained $50 \mathrm{mg}$ of quinine and $15 \mathrm{mg}$ of substrate dissolved in $0.6 \mathrm{~mL}$ of $\mathrm{CDCl}_{3}$.

(S)-(3,3-difluoro-2-hydroxypropyl)phosphonate (1b). Analogously to the preparation of $(S)-1 \mathrm{a},(S)$ 1b was obtained in $87 \%$ yield. ${ }^{1} \mathrm{H}$ NMR $\left(500 \mathrm{MHz}, \mathrm{D}_{2} \mathrm{O}\right) \delta 5.91(\mathrm{~m}, J=55.2,2.4 \mathrm{~Hz}, 1 \mathrm{H}), 4.20-4.03$ $(\mathrm{m}, 1 \mathrm{H}), 2.03-1.79(\mathrm{~m}, 2 \mathrm{H}) .{ }^{19} \mathrm{~F}$ NMR (471 MHz, $100 \mathrm{mM} \mathrm{NaOD}$ in $\left.\mathrm{D}_{2} \mathrm{O}\right) \delta-129.12(\mathrm{ddd}, J=279.5$, 54.9, 8.9 Hz), -134.11 (ddd, $J=279.8,55.3,16.1 \mathrm{~Hz}) .{ }^{31} \mathrm{P}$ NMR $\left(202 \mathrm{MHz}, 100 \mathrm{mM} \mathrm{NaOD}\right.$ in $\left.\mathrm{D}_{2} \mathrm{O}\right) \delta$ $16.77(\mathrm{~m}, J=16.6,8.3 \mathrm{~Hz}) .{ }^{13} \mathrm{C}$ NMR $\left(126 \mathrm{MHz}, \mathrm{D}_{2} \mathrm{O}\right) \delta 115.72(\mathrm{td}, J=242.2,14.1 \mathrm{~Hz}), 66.89(\mathrm{td}, J=$ 22.6, $2.7 \mathrm{~Hz}$ ), 29.06 (ddd, $J=133.3,4.0,2.2 \mathrm{~Hz}$ ). HRMS (ESI): calcd for $\mathrm{C}_{3} \mathrm{H}_{6} \mathrm{~F}_{2} \mathrm{O}_{4} \mathrm{P}\left(\mathrm{M}^{-} \mathrm{H}^{-}\right)$174.9977, found 174.9983 .

6.3 Synthesis of $(S)-3,3,3-F_{3}-H P P(1 c)$.

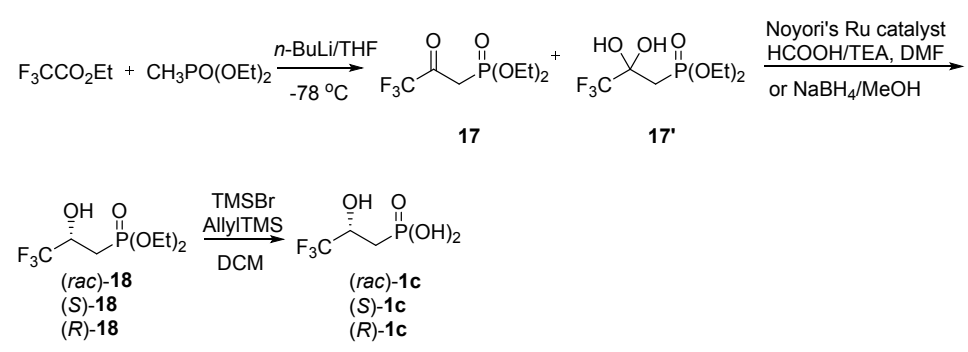

Diethyl (3,3,3-trifluoro-2-oxopropyl)phosphonate (17) and diethyl (3,3,3-trifluoro-2,2dihydroxypropyl)phosphonate $\left(\mathbf{1 7}^{\prime}\right)$. The published procedures of Yuan et al. were followed. ${ }^{16}$ To a mixture of THF $(60 \mathrm{~mL})$ and diethyl methylphosphonate $(15 \mathrm{~g}, 98 \mathrm{mmol})$ cooled to $-78^{\circ} \mathrm{C}$ were gradually 
added $n$-BuLi $(1.6 \mathrm{~mol})$ in $n$-hexane $(67 \mathrm{~mL})$ and ethyl trifluoroacetate $(14.5 \mathrm{~g}, 105 \mathrm{mmol})$. The reaction temperature was kept under $-65{ }^{\circ} \mathrm{C}$ while the mixture was stirred for an additional $3 \mathrm{~h}$ before it was quenched by addition of $1 N \mathrm{HCl}(30 \mathrm{~mL})$. The reaction mixture was then extracted with ether, washed with aqueous $\mathrm{NaHCO}_{3}$ solution, and dried over $\mathrm{Na}_{2} \mathrm{SO}_{4}$. Subsequent concentration under reduced pressure gave an oily residue that was purified by flash chromatography on silica gel with hexanes/ethyl acetate (1/1) as the eluting solvent to yield $\mathbf{1 7}$ and $\mathbf{1 7}$ ' in a ratio of $13 / 87$ as crystalline product $(8.5 \mathrm{~g}$, 70\%). ${ }^{1} \mathrm{H}$ NMR (360 MHz, $\left.\mathrm{CDCl}_{3}\right) \delta 5.70\left(\mathrm{br}, \mathrm{s}, 2 \mathrm{H}, \mathrm{C}(\mathrm{OH})_{2} \mathrm{CH}_{2} \mathrm{P}\right), 4.18\left(\mathrm{q}, 4 \mathrm{H}, \mathrm{P}\left(\mathrm{OCH}_{2} \mathrm{CH}_{3}\right)_{2}\right), 3.37$ $\left(\mathrm{d}, J=22.7 \mathrm{~Hz}, 2 \mathrm{H}, \mathrm{COCH}_{2} \mathrm{P}\right), 2.30\left(\mathrm{~d}, J=19.3 \mathrm{~Hz}, 2 \mathrm{H}, \mathrm{C}(\mathrm{OH})_{2} \mathrm{CH}_{2} \mathrm{P}\right), 1.34(\mathrm{t}, J=7.1 \mathrm{~Hz}, 6 \mathrm{H}$, $\left.\mathrm{P}\left(\mathrm{OCH}_{2} \mathrm{CH}_{3}\right)_{2}\right) .{ }^{19} \mathrm{~F} \mathrm{NMR}\left(282 \mathrm{MHz}, \mathrm{CDCl}_{3}\right) \delta-79.20,-87.71\left(\mathrm{CF}_{3} \mathrm{C}(\mathrm{OH})_{2}\right) .{ }^{31} \mathrm{P} \mathrm{NMR}\left(146 \mathrm{MHz}, \mathrm{CDCl}_{3}\right)$ $\delta 26.16\left(\mathrm{C}(\mathrm{OH})_{2} \mathrm{CH}_{2} \mathrm{P}\right), 15.75$.

Diethyl $(S)-(3,3,3-t r i f l u o r o-2-h y d r o x y p r o p y l) p h o s p h o n a t e ~((S)-18)$. The synthesis was carried out in accordance with published procedures. ${ }^{17-18}$ To an 8 -mL DMF solution of $\operatorname{RuCl}(p$-cymene $)[(R, R)-T s-$ DPEN] (100 mg, 4\%) was added the 17 and $\mathbf{1 7}^{\prime}(1 \mathrm{~g}, 4 \mathrm{mmol})$, followed by addition of $\mathrm{HCO}_{2} \mathrm{H} / \mathrm{Et}_{3} \mathrm{~N}$ $(\mathrm{v} / \mathrm{v}=5 / 2,2.08 \mathrm{~mL})$. The mixture was then stirred at $28^{\circ} \mathrm{C}$ under $\mathrm{N}_{2}$, and the evolution of the reaction was monitored by TLC. The reaction mixture was subsequently diluted with water $(40 \mathrm{~mL})$ and extracted with ethyl acetate $(40 \mathrm{~mL} \times 3)$. The combined organic layer was then dried over $\mathrm{MgSO}_{4}$ and concentrated before the crude product was purified by flash chromatography on silica gel (elution gradient from hexanes/ethyl acetate $=1 / 1$ to $100 \%$ ethyl acetate) to afford $(S)-18(700 \mathrm{mg}, 69 \%)$ as an oil with $99 \%$ enantiomeric excess (e.e.) as determined by ${ }^{31} \mathrm{P}$ NMR using quinine as chiral solvating agent ${ }^{14-15}$ (Figure S24), ${ }^{31} \mathrm{P} \mathrm{NMR}\left(146 \mathrm{MHz}, \mathrm{CDCl}_{3}\right) \delta 27.95 .{ }^{1} \mathrm{H} \mathrm{NMR}\left(360 \mathrm{MHz}, \mathrm{CDCl}_{3}\right) \delta 5.21(\mathrm{~d}, J=5.1 \mathrm{~Hz}, 1 \mathrm{H}), 4.40$ $-4.30(\mathrm{~m}, 1 \mathrm{H}), 4.19-4.06(\mathrm{~m}, 4 \mathrm{H}), 2.16-2.00(\mathrm{~m}, 2 \mathrm{H}), 1.36-1.31(\mathrm{~m}, 6 \mathrm{H}) .{ }^{19} \mathrm{~F}$ NMR $(282 \mathrm{MHz}$, $\left.\mathrm{CDCl}_{3}\right) \delta-81.16(\mathrm{~d}, J=6.5 \mathrm{~Hz})$

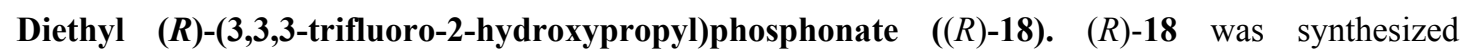
following the same procedure as for $(S)$-18, except $\operatorname{RuCl}(p$-cymene $)[(S, S)$-Ts-DPEN] was used as the catalyst. ${ }^{1} \mathrm{H}$ NMR $\left(360 \mathrm{MHz}, \mathrm{CDCl}_{3}\right) \delta 5.24(\mathrm{br}, 1 \mathrm{H}), 4.40-4.31(\mathrm{~m}, 1 \mathrm{H}), 4.21-4.08(\mathrm{~m}, 4 \mathrm{H}), 2.18-$ $2.04(\mathrm{~m}, 2 \mathrm{H}), 1.38-1.31(\mathrm{~m}, 6 \mathrm{H}) .{ }^{19} \mathrm{~F} \mathrm{NMR}\left(282 \mathrm{MHz}, \mathrm{CDCl}_{3}\right) \delta-81.11(\mathrm{~d}, J=6.4 \mathrm{~Hz})$. The e.e. of $(R)-$ 18 was determined to be $99 \%$ (Figure S24), ${ }^{31} \mathrm{P}$ NMR $\left(146 \mathrm{MHz}, \mathrm{CDCl}_{3}\right) \delta 27.06$. 
Diethyl (rac)-(3,3,3-trifluoro-2-hydroxypropyl)phosphonate ((rac)-18). To a solution of the mixture of 17 and $\mathbf{1 7}^{\prime}(0.5 \mathrm{~g}, 2.02 \mathrm{mmol})$ in methanol $(10 \mathrm{~mL})$, maintained at $\sim 0-5^{\circ} \mathrm{C}$ via the use of an ice bath, was gradually added $\mathrm{NaBH}_{4}(0.23 \mathrm{~g}, 6.05 \mathrm{mmol})$. After $5 \mathrm{~min}$, the reaction mixture was concentrated and purified by chromatography to afford $0.49 \mathrm{~g}$ of $(\mathrm{rac})-\mathbf{1 8}$ as a colorless oily liquid with a yield of 97.5\%. ${ }^{1} \mathrm{H}$ NMR $\left(\mathrm{CDCl}_{3}\right) \delta 5.72(\mathrm{br}, 1 \mathrm{H}), 4.41-4.30(\mathrm{~m}, 1 \mathrm{H}), 4.16-4.06(\mathrm{~m}, 4 \mathrm{H}), 2.21-2.02(\mathrm{~m}, 2 \mathrm{H})$, $1.34-1.29(\mathrm{~m}, 6 \mathrm{H}) .{ }^{19} \mathrm{~F} \mathrm{NMR}\left(282 \mathrm{MHz}, \mathrm{CDCl}_{3}\right) \delta-81.10(\mathrm{~d}, J=6.1 \mathrm{~Hz}) .{ }^{31} \mathrm{P} \mathrm{NMR}\left(146 \mathrm{MHz}, \mathrm{CDCl}_{3}\right)$ $\delta 27.44$.

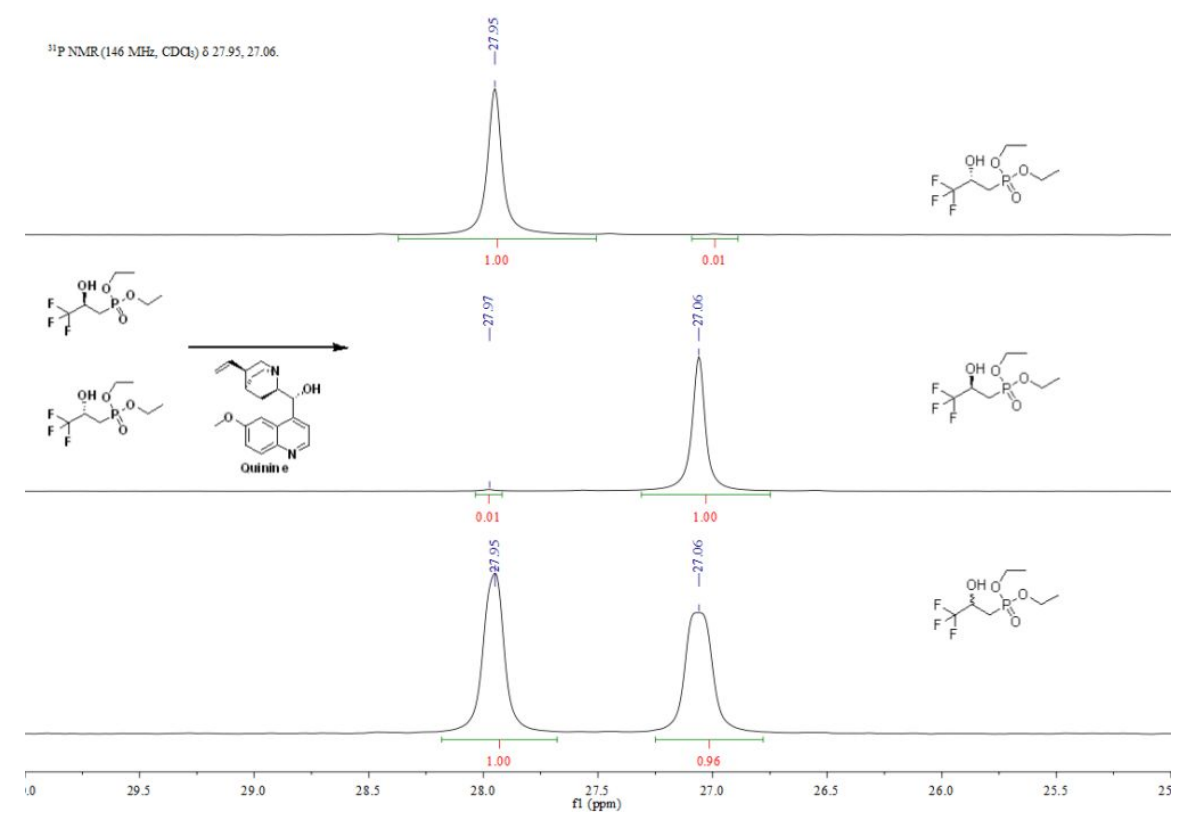

Figure S24. Determination of the e.e. of $(S)-\mathbf{1 8}(99 \%$, top spectrum) and $(R)-\mathbf{1 8}(99 \%$, middle spectrum) by ${ }^{31} \mathrm{P}$ NMR with quinine as a chiral solvating agent. ${ }^{14-15}$ Each sample contained $50 \mathrm{mg}$ of quinine and $15 \mathrm{mg}$ of substrate dissolved in $0.6 \mathrm{~mL}$ of $\mathrm{CDCl}_{3}$.

(S)-(3,3,3-trifluoro-2-hydroxypropyl)phosphonic acid ((S)-1c). TMSBr $(0.61 \mathrm{~g}, 3.96 \mathrm{mmol})$ and allyl trimethylsilane $(0.23 \mathrm{~g}, 2.04 \mathrm{mmol})$ were added to a solution of $(S)-\mathbf{1 8}(0.3 \mathrm{mg}, 1.20 \mathrm{mmol})$ in $\mathrm{CH}_{2} \mathrm{Cl}_{2}(20 \mathrm{~mL})$ at $\mathrm{rt}$, and the solution was stirred overnight. The solvent was subsequently removed under reduced pressure. The residue was resuspended in a solution of $\mathrm{CHCl}_{3}(20 \mathrm{~mL})$ and water $(20$ $\mathrm{mL}$ ). Following neutralization with ammonium bicarbonate, the aqueous layer was collected and lyophilized to afford $(S)-\mathbf{1 c}$ as a white solid $(0.22 \mathrm{~g}, 80 \%)$. The e.e. was determined to be $99 \%$ using $\alpha$-cyclodextrin as chiral solvating agent ${ }^{19-20}$ (Figure S25). ${ }^{1} \mathrm{H}$ NMR $\left(360 \mathrm{MHz}, \mathrm{D}_{2} \mathrm{O}\right) \delta 4.28-4.16(\mathrm{~m}$, $1 \mathrm{H}), 1.85-1.57(\mathrm{~m}, 2 \mathrm{H}) .{ }^{13} \mathrm{C} \mathrm{NMR}\left(75 \mathrm{MHz}, \mathrm{D}_{2} \mathrm{O}\right) \delta 125.49(\mathrm{qd}, J=281.2,19.6 \mathrm{~Hz}), 66.88(\mathrm{qd}, J=$ 
32.1, $4.1 \mathrm{~Hz}), 28.78(\mathrm{~d}, J=134.7 \mathrm{~Hz}) .{ }^{19} \mathrm{~F} \mathrm{NMR}\left(282 \mathrm{MHz}, \mathrm{CDCl}_{3}\right) \delta-81.02(\mathrm{~d}, J=6.7 \mathrm{~Hz}) .{ }^{31} \mathrm{P} \mathrm{NMR}$ (146 MHz, $\left.\mathrm{CDCl}_{3}\right) \delta$ 16.79. HRMS (ESI): calcd for $\mathrm{C}_{3} \mathrm{H}_{5} \mathrm{~F}_{3} \mathrm{O}_{4} \mathrm{P}\left(\mathrm{M}-\mathrm{H}^{-}\right)$192.9883, found 192.9890 .

(R)-(3,3,3-trifluoro-2-hydroxypropyl)phosphonic acid $((R)-1 \mathrm{c})$. The ${ }^{1} \mathrm{H},{ }^{31} \mathrm{P},{ }^{19} \mathrm{~F}$ and ${ }^{13} \mathrm{C}$ NMR spectra of $(R)-\mathbf{1 c}$ were identical to those of $(S)-\mathbf{1 c}$, and the e.e. of $(R)-\mathbf{1 c}$ was likewise determined to be $99 \%$ (Figure S25). ${ }^{19-20}$

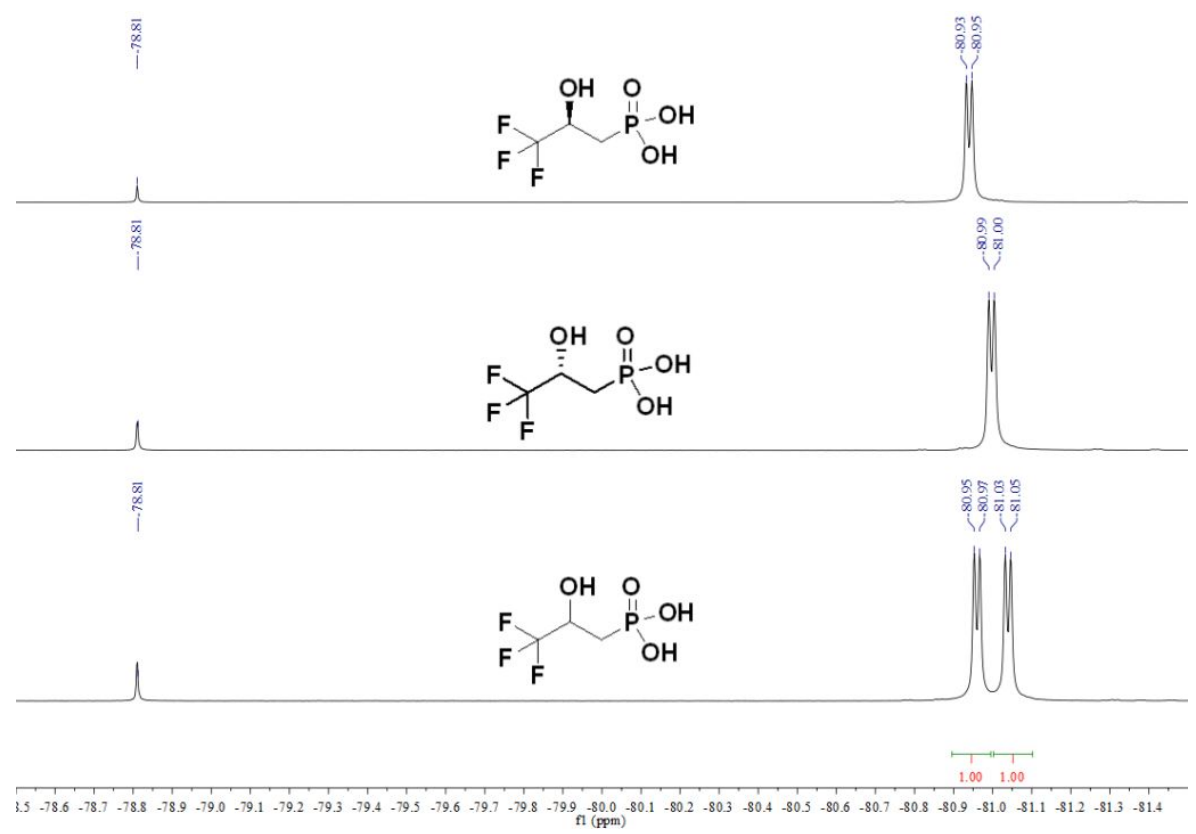

Figure S25. Determination of the e.e. of $(S)-1$ c (99\%, middle spectrum) and $(R)-1 \mathbf{c}(99 \%$, top spectrum) by ${ }^{19} \mathrm{~F}$ NMR utilizing $\alpha$-cyclodextrin as a chiral solvating agent ${ }^{19-20}$ and $\mathrm{NaOTf}$ as an internal standard. Each sample contained $40 \mathrm{mg}$ of $\alpha$-cyclodextrin and $3.6 \mathrm{mM}$ of substrate dissolved in $0.5 \mathrm{~mL}$ of $\mathrm{D}_{2} \mathrm{O}$.

\subsection{Synthesis of 3,3,3-F $-2-O P P(4 c)$.}

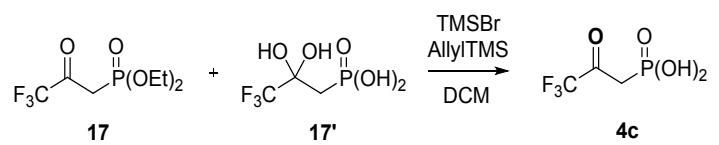

(3,3,3-trifluoro-2,2-dihydroxypropyl)phosphonate (4c). Following the same procedure as for the synthesis of $(S)-\mathbf{1 a}$, compound $\mathbf{4 c}$ was obtained in 70\% yield using the mixture of $\mathbf{1 7}$ and $\mathbf{1 7}$ ' as the starting material. ${ }^{1} \mathrm{H}$ NMR $\left(360 \mathrm{MHz}, \mathrm{D}_{2} \mathrm{O}\right) \delta 2.02(\mathrm{~d}, J=17.2 \mathrm{~Hz}, 2 \mathrm{H}) .{ }^{31} \mathrm{P}$ NMR $\left(146 \mathrm{MHz}, \mathrm{D}_{2} \mathrm{O}\right) \delta$ 16.02. ${ }^{19} \mathrm{~F}$ NMR $\left(282 \mathrm{MHz}, \mathrm{D}_{2} \mathrm{O}\right) \delta-87.28 .{ }^{13} \mathrm{C} \mathrm{NMR}\left(75 \mathrm{MHz}, \mathrm{D}_{2} \mathrm{O}\right) \delta 123.23(\mathrm{qd}, J=285.6,15.9 \mathrm{~Hz})$, $92.34(\mathrm{qd}, J=33.7,8.0 \mathrm{~Hz}), 31.03(\mathrm{~d}, J=122.9 \mathrm{~Hz})$. HRMS (ESI): calcd for $\mathrm{C}_{3} \mathrm{H}_{3} \mathrm{~F}_{3} \mathrm{O}_{4} \mathrm{P}\left(\mathrm{M}-\mathrm{H}^{-}\right)$190.9726, found 190.9733 . 
6.5 Synthesis of (1R,2S)-1-Cl-3,3,3-F $\mathrm{F}_{3}-\mathrm{HPP}(1 \mathrm{f})$ and anti-1-Cl-3,3,3-F $-\mathrm{H}-\mathrm{HPP}(1 \mathrm{~g})$.

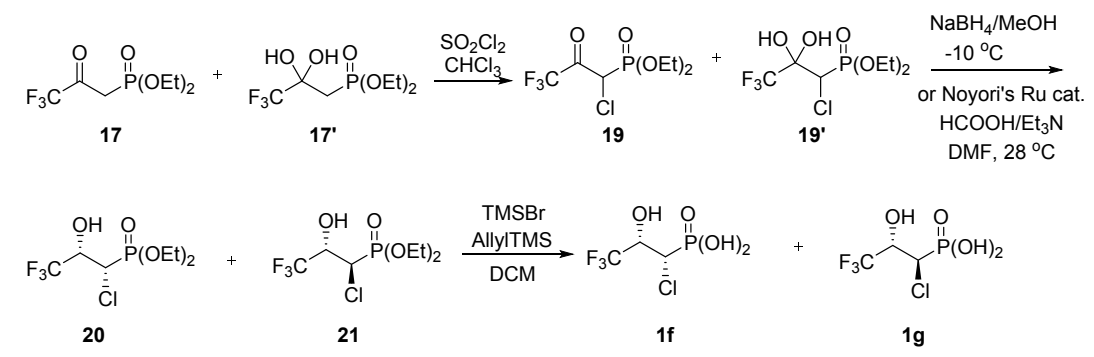

Diethyl (1-chloro-3,3,3-trifluoro-2-oxopropyl)phosphonate (19) and diethyl (1-chloro-3,3,3trifluoro-2,2-dihydroxypropyl)phosphonate (19'). Following published procedures of Marocco et al., ${ }^{4}$ sulfuryl chloride ( $977 \mu \mathrm{L}, 12.09 \mathrm{mmol})$ was dripped into a solution of $\mathbf{1 7}$ and $\mathbf{1 7}$ ( $(3 \mathrm{~g}, 12.09 \mathrm{mmol})$ in $24 \mathrm{~mL}$ of $\mathrm{CHCl}_{3}$ at $0{ }^{\circ} \mathrm{C}$. The reaction was then allowed to stir for $4 \mathrm{~h}$ at $\mathrm{rt}$ before being quenched by the addition of water $(25 \mathrm{~mL})$ and extracted with methylene chloride $(3 \times 25 \mathrm{~mL})$. The combined organic layers were subsequently dried over $\mathrm{MgSO}_{4}$, filtered, and concentrated under reduced pressure. The crude oil obtained was purified by flash chromatography $(\mathrm{DCM} /$ acetone $=8 / 1)$ to give $2.5 \mathrm{~g}$ of $\mathbf{1 9}$ and $1^{1}{ }^{\prime}$ as an oil in a ratio of $1 / 10$ and $73 \%$ overall yield. ${ }^{1} \mathrm{H}$ NMR $\left(360 \mathrm{MHz}, \mathrm{CDCl}_{3}\right) \delta 6.44(\mathrm{br}, 1 \mathrm{H}$, $\left.\mathrm{C}(\mathrm{OH})_{2} \mathrm{CHClP}\right), 5.48$ (br, $\left.1 \mathrm{H}, \mathrm{C}(\mathrm{OH})_{2} \mathrm{CHClP}\right), 5.04(\mathrm{~d}, J=17.7 \mathrm{~Hz}, \mathrm{COCHClP}), 4.38-4.20(\mathrm{~m}, 4 \mathrm{H}$, $\left.\mathrm{P}\left(\mathrm{OCH}_{2} \mathrm{CH}_{3}\right)_{2}\right), 4.16\left(\mathrm{~d}, J=14.1 \mathrm{~Hz}, 1 \mathrm{H}, \mathrm{C}(\mathrm{OH})_{2} \mathrm{CHClP}\right), 1.40-1.35\left(\mathrm{~m}, 6 \mathrm{H}, \mathrm{P}\left(\mathrm{OCH}_{2} \mathrm{CH}_{3}\right)_{2}\right) .{ }^{19} \mathrm{~F} \mathrm{NMR}$ $\left(282 \mathrm{MHz}, \mathrm{CDCl}_{3}\right) \delta-75.68,-81.84\left(\mathrm{CF}_{3} \mathrm{C}(\mathrm{OH})_{2} \mathrm{CHClP}\right) .{ }^{31} \mathrm{P} \mathrm{NMR}\left(146 \mathrm{MHz}, \mathrm{CDCl}_{3}\right) \delta 17.23$ $\left(\mathrm{CF}_{3} \mathrm{C}(\mathrm{OH})_{2} \mathrm{CHClP}\right), 9.35$.

Diethyl $((1 R, 2 S)$-1-chloro-3,3,3-trifluoro-2-hydroxypropyl)phosphonate $((1 R, 2 S)-20)$ and Diethyl ((1S,2S)-1-chloro-3,3,3-trifluoro-2-hydroxypropyl)phosphonate $((1 S, 2 S)-21)$. The synthesis was carried out in accordance with published procedures. ${ }^{17-18}$ To an 8-mL DMF solution of $\operatorname{RuCl}(p-$ cymene)[(R,R)-Ts-DPEN] (89.77 $\mathrm{mg}, 4 \%)$ was added the 19 and 19' (1 g, $3.54 \mathrm{mmol})$ followed by the addition of $\mathrm{HCO}_{2} \mathrm{H} / \mathrm{Et}_{3} \mathrm{~N}(\mathrm{v} / \mathrm{v}=5 / 2,1.83 \mathrm{~mL})$. The mixture was then stirred at $28{ }^{\circ} \mathrm{C}$ under $\mathrm{N}_{2}$, and the evolution of the reaction was monitored by TLC. The reaction solution was diluted with water $(40 \mathrm{~mL})$ and extracted with ethyl acetate $(40 \mathrm{~mL} \times 3)$. The combined organic layer was subsequently dried over $\mathrm{MgSO}_{4}$ and concentrated. The crude product was purified by flash chromatography on silica gel (elution gradient from hexanes/ethyl acetate $=1 / 1$ to $100 \%$ ethyl acetate $)$ to afford $(1 R, 2 S)$-20 and $(1 S, 2 S)-\mathbf{2 1}(350$ $\mathrm{mg}, 35 \%)$ in a ratio (d.r.) of $92 / 8$ as an oil. The e.e. value $(98 \%)$ of $(1 R, 2 S)-20$ was determined by ${ }^{31} \mathrm{P}$ NMR with quinine as the chiral solvating agent ${ }^{14-15}$ (Figure S26). ${ }^{1} \mathrm{H}$ NMR $\left(360 \mathrm{MHz}, \mathrm{CDCl}_{3}\right) \delta 5.11$ 
(br, 1H), $4.65(\mathrm{p}, J=6.7 \mathrm{~Hz}, 1 \mathrm{H}), 4.34-4.15(\mathrm{~m}, 5 \mathrm{H}), 1.36(\mathrm{td}, J=7.1,2.6 \mathrm{~Hz}, 6 \mathrm{H}) .{ }^{19} \mathrm{~F}$ NMR $(282$ $\left.\mathrm{MHz}, \mathrm{CDCl}_{3}\right) \delta-76.19(\mathrm{~d}, J=6.1 \mathrm{~Hz},(1 S, 2 S)-21),-76.37(\mathrm{dd}, J=6.6,2.7 \mathrm{~Hz},(1 R, 2 S)-20) .{ }^{31} \mathrm{P}$ NMR (146 MHz, $\left.\mathrm{CDCl}_{3}\right) \delta 16.83((1 S, 2 S)-21), 16.39((1 R, 2 S)-20)$.

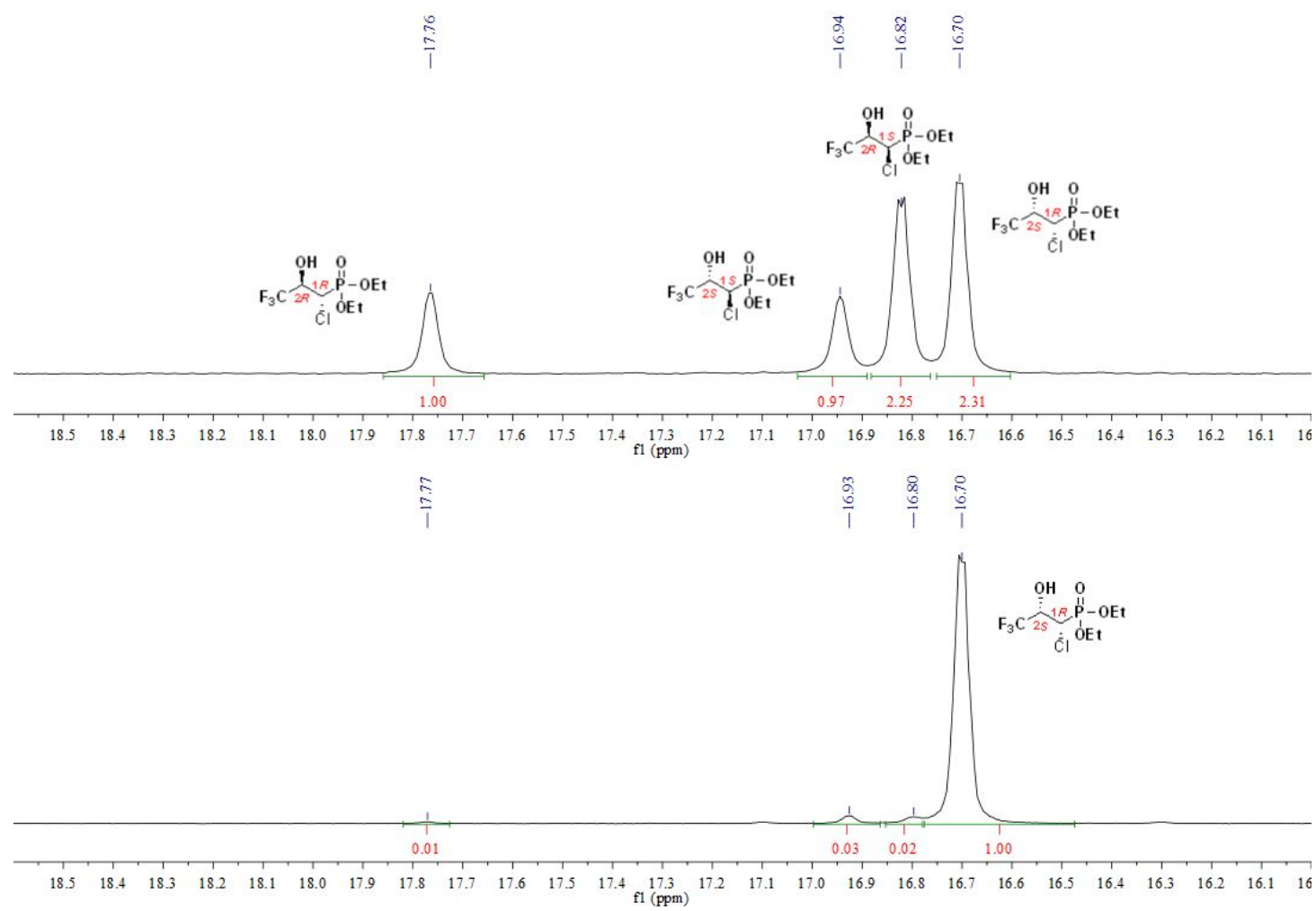

Figure S26. Determination of the e.e. of $(1 R, 2 S)-\mathbf{2 0}\left(98 \%\right.$, bottom spectrum) via ${ }^{31} \mathrm{P}$ NMR, with racemic anti-21 and syn-20 (top spectrum) as controls. Quinine was added as a chiral solvating agent. ${ }^{14-15}$ Each sample contained $50 \mathrm{mg}$ of quinine and $15 \mathrm{mg}$ of substrate dissolved in $0.6 \mathrm{~mL}$ of $\mathrm{CDCl}_{3}$.

((1R,2S)-1-chloro-3,3,3-trifluoro-2-hydroxypropyl)phosphonate (1f). TMSBr (0.46 g, 3.48 mmol) and allyl trimethylsilane $(0.28 \mathrm{~g}, 1.79 \mathrm{mmol})$ were added to a solution of $(1 R, 2 S)-\mathbf{2 0}(0.3 \mathrm{mg}, 1.05 \mathrm{mmol})$ in $\mathrm{CH}_{2} \mathrm{Cl}_{2}(20 \mathrm{~mL})$ at $\mathrm{rt}$, and the solution was stirred for $48 \mathrm{~h}$. The solvent was subsequently removed under reduced pressure, and the residue was dissolved in $\mathrm{CHCl}_{3}(20 \mathrm{~mL})$ before being extracted with 30 $\mathrm{mL}$ of an aqueous $0.2 \mathrm{M}$ ammonium acetate solution. The aqueous layer was then collected and lyophilized to afford $(1 R, 2 S)-1 \mathrm{f}$ as a white solid $(0.18 \mathrm{~g}, 75 \%) .{ }^{1} \mathrm{H}$ NMR $\left(500 \mathrm{MHz}, \mathrm{D}_{2} \mathrm{O}\right) \delta 4.68(\mathrm{p}, J=$ $6.9 \mathrm{~Hz}, 1 \mathrm{H}), 4.03(\mathrm{~d}, J=12.8 \mathrm{~Hz}, 1 \mathrm{H}) .{ }^{31} \mathrm{P}$ NMR $\left(202 \mathrm{MHz}, \mathrm{D}_{2} \mathrm{O}\right) \delta 11.13 .{ }^{19} \mathrm{~F} \mathrm{NMR}\left(471 \mathrm{MHz}, \mathrm{D}_{2} \mathrm{O}\right) \delta$ $-75.74(\mathrm{~d}, J=7.1 \mathrm{~Hz}) \cdot{ }^{13} \mathrm{C}$ NMR $\left(126 \mathrm{MHz}, \mathrm{D}_{2} \mathrm{O}\right) \delta 124.28(\mathrm{qd}, J=281.8,16.4 \mathrm{~Hz}), 69.04(\mathrm{q}, J=31.2$ $\mathrm{Hz}$ ), $51.90(\mathrm{~d}, J=131.3 \mathrm{~Hz})$. HRMS (ESI): calcd for $\mathrm{C}_{3} \mathrm{H}_{4} \mathrm{ClF}_{3} \mathrm{O}_{4} \mathrm{P}\left(\mathrm{M}-\mathrm{H}^{-}\right) 226.9493$, found 226.9501. 
rac-Diethyl (1-chloro-3,3,3-trifluoro-2-hydroxypropyl)phosphonate (21). Following the synthesis of rac-15, $\mathrm{NaBH}_{4}$ reduction at rt gave rac-21 $(0.6 \mathrm{~g}, 59 \%$, d.r. 32/68) as a colorless oily liquid. By contrast, reduction at $-10^{\circ} \mathrm{C}$ afforded $\mathrm{rac}-\mathbf{2 1}$ with a d.r. of 59/41.

rac-anti-(1-chloro-3,3,3-trifluoro-2-hydroxypropyl)phosphonate (1g). TMSBr (0.92 g, 6.96 mmol) and allyl trimethylsilane $(0.56 \mathrm{~g}, 3.58 \mathrm{mmol})$ were added to a solution of 21 (0.6 mg, $2.1 \mathrm{mmol}$, d.r. 59/41) in $\mathrm{CH}_{2} \mathrm{Cl}_{2}(20 \mathrm{~mL})$ at $\mathrm{rt}$, and the solution was stirred for $48 \mathrm{~h}$. The solvent was subsequently removed under reduced pressure, and the residue was dissolved in $\mathrm{CHCl}_{3}(20 \mathrm{~mL})$ before being extracted with $30 \mathrm{~mL}$ of an aqueous $0.2 \mathrm{M}$ ammonium bicarbonate solution. The aqueous layer was then collected and evaporated under vacuum to afford $\mathbf{1 g}$ as a white solid $(0.36 \mathrm{~g}, 75 \%)$. Further purification was achieved when the mixture of anti-1g and syn-1f was resuspended in $5 \mathrm{~mL}$ of ethanol, stirred for $0.5 \mathrm{~h}$, and then filtered. Evaporation of the filtrate under vacuum afforded relatively pure anti-1g. ${ }^{1} \mathrm{H}$ NMR $\left(500 \mathrm{MHz}, \mathrm{D}_{2} \mathrm{O}\right) \delta 4.49-4.42(\mathrm{~m}, 1 \mathrm{H}), 4.03(\mathrm{dd}, J=12.2,7.4 \mathrm{~Hz}, 1 \mathrm{H}) .{ }^{31} \mathrm{P}$ NMR $\left(202 \mathrm{MHz}, \mathrm{D}_{2} \mathrm{O}\right) \delta$ 11.16, 11.36. ${ }^{19} \mathrm{~F}$ NMR $\left(471 \mathrm{MHz}, \mathrm{D}_{2} \mathrm{O}\right) \delta-74.46(\mathrm{~d}, J=6.6 \mathrm{~Hz}) .{ }^{13} \mathrm{C}$ NMR $\left(126 \mathrm{MHz}, \mathrm{D}_{2} \mathrm{O}\right) \delta 123.24$ (qd, $J=282.7,12.6 \mathrm{~Hz}), 70.64(\mathrm{q}, J=30.1 \mathrm{~Hz}), 50.57(\mathrm{~d}, J=133.5 \mathrm{~Hz})$. HRMS (ESI): calcd for $\mathrm{C}_{3} \mathrm{H}_{4} \mathrm{ClF}_{3} \mathrm{O}_{4} \mathrm{P}\left(\mathrm{M}-\mathrm{H}^{-}\right)$226.9493, found 226.9502.

\subsection{Chemical synthesis of cis- and trans $-3,3,3-F_{3}-F o s(2 c$ and $3 c)$ standards.}

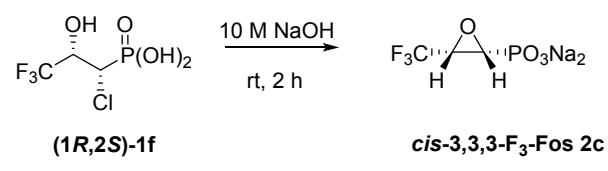

(1R,2S)-1,2-epoxy-3,3,3-trifluoropropylphosphonate (2c). Published procedures of Marocco et al. were followed. ${ }^{4}$ To a solution of $10 \mathrm{M} \mathrm{NaOH}(200 \mu \mathrm{L})$ was added $(1 R, 2 S)-\mathbf{1 f}(20 \mathrm{mg}, 0.087 \mathrm{mmol})$. The reaction was stirred for $2 \mathrm{~h}$ and diluted with $400 \mu \mathrm{L}$ of $\mathrm{D}_{2} \mathrm{O}$, before being transferred to an NMR tube. $(1 R, 2 S)-2 \mathrm{c}$ was generated in a $30 \%$ calculated yield. ${ }^{1} \mathrm{H}$ NMR $\left(500 \mathrm{MHz}, 2 \mathrm{M} \mathrm{NaOH}\right.$ in $\left.\mathrm{D}_{2} \mathrm{O}\right) \delta 3.58-$ $3.53(\mathrm{~m}, 1 \mathrm{H}), 2.91(\mathrm{dd}, J=15.5,5.0 \mathrm{~Hz}, 1 \mathrm{H}) .{ }^{19} \mathrm{~F} \mathrm{NMR}\left(471 \mathrm{MHz}, 2 \mathrm{M} \mathrm{NaOH}\right.$ in $\left.\mathrm{D}_{2} \mathrm{O}\right) \delta-67.83(\mathrm{~d}, J=$ $6.5 \mathrm{~Hz}) .{ }^{31} \mathrm{P}$ NMR $\left(202 \mathrm{MHz}, 2 \mathrm{M} \mathrm{NaOH}\right.$ in $\left.\mathrm{D}_{2} \mathrm{O}\right) \delta 5.32(\mathrm{~d}, J=16.0 \mathrm{~Hz})$. 


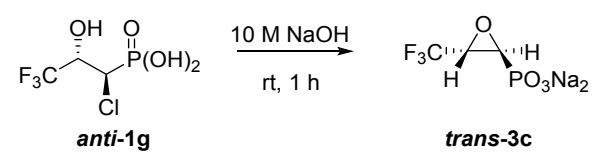

Trans-1,2-epoxy-3,3,3-trifluoropropylphosphonate (3c) To a solution of $10 \mathrm{M} \mathrm{NaOH}(200 \mu \mathrm{L})$ was added anti-1g (20 mg, $0.087 \mathrm{mmol})$. The reaction was subsequently stirred for $1 \mathrm{~h}$ before being diluted with $400 \mu \mathrm{L} \mathrm{D}_{2} \mathrm{O}$ and transferred to an NMR tube. Compound trans-3c was generated in a $90 \%$ calculated yield. ${ }^{1} \mathrm{H}$ NMR $\left(500 \mathrm{MHz}, 2 \mathrm{M} \mathrm{NaOH}\right.$ in $\left.\mathrm{D}_{2} \mathrm{O}\right) \delta 3.58-3.54(\mathrm{~m}, 1 \mathrm{H}), 2.99(\mathrm{dd}, J=19.8,2.8 \mathrm{~Hz}, 1 \mathrm{H})$. ${ }^{19} \mathrm{~F}$ NMR $\left(471 \mathrm{MHz}, 2 \mathrm{M} \mathrm{NaOH}\right.$ in $\left.\mathrm{D}_{2} \mathrm{O}\right) \delta-74.13(\mathrm{~d}, J=5.0 \mathrm{~Hz}) .{ }^{31} \mathrm{P} \mathrm{NMR}(202 \mathrm{MHz}, 2 \mathrm{M} \mathrm{NaOH}$ in $\left.\mathrm{D}_{2} \mathrm{O}\right) \delta 6.75(\mathrm{dd}, J=19.8,4.4 \mathrm{~Hz})$.

\subsection{Synthesis of $(1 R, 2 S)-1-F-H P P(1 h)$ and 1-F-2-OPP (4h) using adaptions of previously published} methods. ${ }^{21-23}$
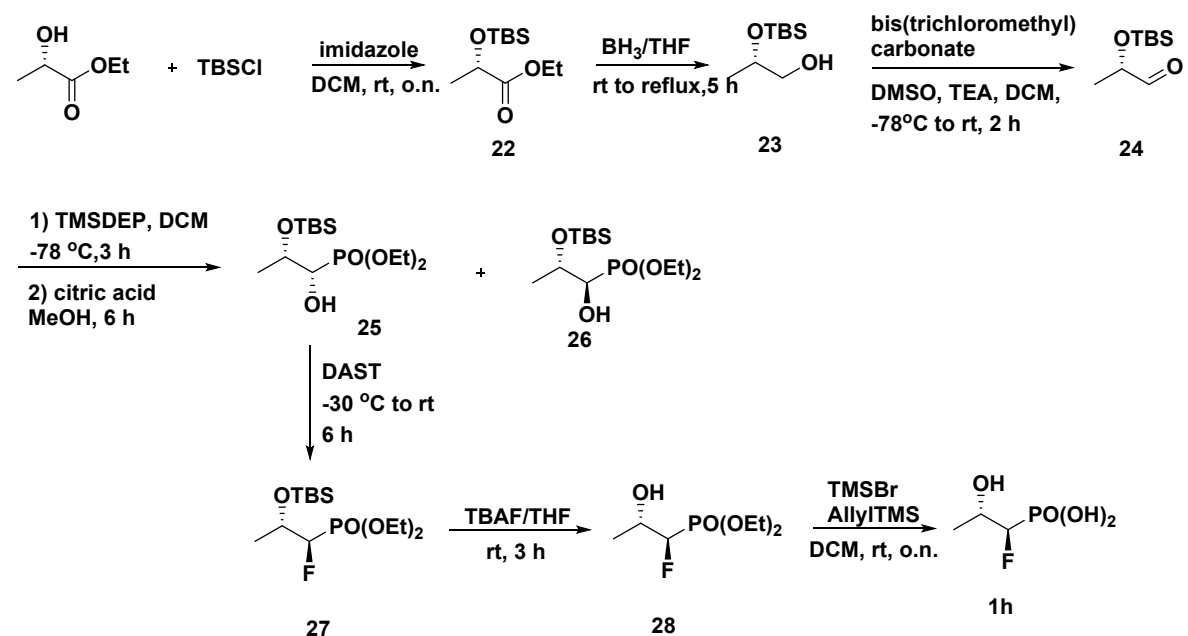

Ethyl (S)-2-((tert-butyldimethylsilyl)oxy)propanoate (22). To a stirred solution of (-)-ethyl $L$-lactate (5.00 ml, $44.1 \mathrm{mmol})$ and imidazole $\left(7.51 \mathrm{~g}, 110.26 \mathrm{mmol}, 2.5\right.$ equiv) in $\mathrm{CH}_{2} \mathrm{Cl}_{2}(100 \mathrm{~mL})$ was added tert-butyldimethylsilyl chloride (7.98 g, $52.92 \mathrm{mmol}, 1.2$ equiv) at $\mathrm{rt}$ under nitrogen atmosphere. After $18 \mathrm{~h}$, the reaction mixture was quenched by addition of water $(100 \mathrm{~mL})$. The aqueous phase was then extracted 3 times with $\mathrm{CH}_{2} \mathrm{Cl}_{2}$, washed with brine, dried over $\mathrm{MgSO}_{4}$, filtered, and concentrated before being purified by chromatography (hexanes/ethyl acetate $=20 / 1)$ to yield $22(10.25 \mathrm{~g}, 43.1 \mathrm{mmol}$, quant. yield) as a colorless oil. ${ }^{1} \mathrm{H}$ NMR $\left(500 \mathrm{MHz} \mathrm{CDCl}_{3}\right) \delta 4.28(\mathrm{q}, J=6.8 \mathrm{~Hz}, 1 \mathrm{H}), 4.20-4.10(\mathrm{~m}, 2 \mathrm{H}), 1.37$ $(\mathrm{d}, J=6.7 \mathrm{~Hz}, 3 \mathrm{H}), 1.25(\mathrm{t}, J=7.2 \mathrm{~Hz}, 3 \mathrm{H}), 0.88(\mathrm{~s}, 9 \mathrm{H}), 0.07(\mathrm{~s}, 3 \mathrm{H}), 0.04(\mathrm{~s}, 3 \mathrm{H}) .{ }^{13} \mathrm{C} \mathrm{NMR}(126 \mathrm{MHz}$, $\left.\mathrm{CDCl}_{3}\right) \delta 174.05,68.42,60.68,25.68,21.27,18.29,14.16,-4.98,-5.31 .{ }^{13} \mathrm{C} \mathrm{NMR}\left(126 \mathrm{MHz}, \mathrm{CDCl}_{3}\right) \delta$ $69.06,68.15,25.81,19.82,18.05,-4.41,-4.81$. 
(S)-2-((tert-butyldimethylsilyl)oxy)propan-1-ol (23). Into a solution of (S)-ethyl 2-((tertbutyldimethylsilyl)oxy)propanoate $(10.25 \mathrm{~g}, 44.10 \mathrm{mmol})$ was dripped $\mathrm{BH}_{3} \cdot \mathrm{THF}(88.2 \mathrm{~mL}, 88.2 \mathrm{mmol}$, 1M). The reaction mixture was subsequently heated to reflux for $5 \mathrm{~h}$ before water was slowly added. The aqueous layer was then extracted with $\mathrm{CH}_{2} \mathrm{Cl}_{2}(2 \times 500 \mathrm{~mL})$, dried over $\mathrm{MgSO}_{4}$, concentrated, and purified by chromatography (hexanes/ethyl acetate $=10 / 1)$ to afford $\mathbf{2 3}(8.40 \mathrm{~g}, 44.10 \mathrm{mmol}$, quant. yield) as a colorless oil. ${ }^{1} \mathrm{H}$ NMR $\left(500 \mathrm{MHz}, \mathrm{CDCl}_{3}\right) \delta 3.98-3.84(\mathrm{~m}, 1 \mathrm{H}), 3.50-3.46(\mathrm{~m}, 1 \mathrm{H}), 3.39-3.30(\mathrm{~m}$, 1H), $2.08-1.99(\mathrm{~m}, 1 \mathrm{H}), 1.10(\mathrm{~d}, J=6.2 \mathrm{~Hz}, 3 \mathrm{H}), 0.89(\mathrm{~s}, 9 \mathrm{H}), 0.07(\mathrm{~s}, 6 \mathrm{H}) .{ }^{13} \mathrm{C} \mathrm{NMR}(126 \mathrm{MHz}$, $\left.\mathrm{CDCl}_{3}\right) \delta 69.06,68.15,25.81,19.82,18.05,-4.41,-4.81$

(S)-2-((tert-butyldimethylsilyl)oxy)propanal (24). To a stirred solution of bis(trichloromethyl) carbonate $(3.12 \mathrm{~g}, 10.51 \mathrm{mmol})$ in $\mathrm{CH}_{2} \mathrm{Cl}_{2}(30 \mathrm{~mL})$ at $-78{ }^{\circ} \mathrm{C}$ was added DMSO $(4.5 \mathrm{~mL}, 63.04 \mathrm{mmol})$. The reaction mixture was stirred for 15 min before a solution of $23(5 \mathrm{~g}, 26.27 \mathrm{mmol})$ in $\mathrm{CH}_{2} \mathrm{Cl}_{2}(20$ $\mathrm{mL})$ was slowly added at the same temperature. After $15 \mathrm{~min}$ of stirring, triethylamine $(10.27 \mathrm{~mL}, 73.55$ mmol) in $\mathrm{CH}_{2} \mathrm{Cl}_{2}(40 \mathrm{~mL})$ was dripped in while the temperature was maintained below $-70{ }^{\circ} \mathrm{C}$. After this addition, the resulting suspension was stirred at $-78^{\circ} \mathrm{C}$ for another 5 min before the acetone-dry ice bath was removed. The reaction mixture was subsequently stirred at $\mathrm{rt}$ for $2 \mathrm{~h}$ and then was washed with $1 \mathrm{~N} \mathrm{HCl}(100 \mathrm{~mL} \times 2)$. Evaporation of the organic solvent under reduced pressure produced a residue, which was purified by a short column (hexanes/ethyl acetate $=20 / 1)$ to afford $24(4.3 \mathrm{~g}, 82 \%)$ : ${ }^{1} \mathrm{H}$ NMR $\left(500 \mathrm{MHz}, \mathrm{CDCl}_{3}\right) \delta 9.59(\mathrm{~s}, 1 \mathrm{H}), 4.07$ (q, $\left.J=6.8 \mathrm{~Hz}, 1 \mathrm{H}\right), 1.25(\mathrm{~d}, J=6.9 \mathrm{~Hz}, 3 \mathrm{H}), 0.90(\mathrm{~s}, 9 \mathrm{H}), 0.08$ $(\mathrm{d}, J=6.1 \mathrm{~Hz}, 6 \mathrm{H}) .{ }^{13} \mathrm{C} \mathrm{NMR}\left(126 \mathrm{MHz}, \mathrm{CDCl}_{3}\right) \delta 204.06,73.80,25.71,18.47,18.14,-4.78,-4.84$.

Diethyl ((4S,5S)-2,2,5,7,7,8,8-heptamethyl-3,6-dioxa-2,7-disilanonan-4-yl)phosphonate (25). To a stirred solution of silylphosphonic ester (TMSDEP, $23.36 \mathrm{mmol}$ ) [prepared in situ in $\mathrm{CH}_{2} \mathrm{Cl}_{2}(200 \mathrm{~mL})$ from DEP (3.23 g, $23.36 \mathrm{mmol})$, TEA (2.79g, $27.61 \mathrm{mmol})$, TMSC1 (3 g, $27.61 \mathrm{mmol})$ under an argon atmosphere at $0{ }^{\circ} \mathrm{C}$ for $\left.\left.30 \mathrm{~min}\right)\right],(S)$-lactaldehyde $24(4 \mathrm{~g}, 21.24 \mathrm{mmol})$ in $80 \mathrm{~mL} \mathrm{CH}_{2} \mathrm{Cl}_{2}$ was slowly added at $-78^{\circ} \mathrm{C}$, and the reaction mixture was stirred at the same temperature for $3 \mathrm{~h}$. Water was added to quench the reaction, and the mixture was warmed to $0{ }^{\circ} \mathrm{C}$. The mixture was then extracted with $\mathrm{CH}_{2} \mathrm{Cl}_{2}$ and washed with brine. Concentration in vacuo yielded the crude adducts (syn/anti $=3 / 1$, as determined by $\left.{ }^{31} \mathrm{P}-\mathrm{NMR}\right)$. Exposure of the crude mixture to citric acid $(2 \mathrm{eq})$ in methanol $(300 \mathrm{~mL})$ at $\mathrm{rt}$ for $6 \mathrm{~h}$ followed by silica gel chromatography $\left(\mathrm{CH}_{2} \mathrm{Cl}_{2}\right.$ /acetone $\left.=16 / 1\right)$ gave the hydroxyphosphonic esters, 25 
and 26 ( 3 g, total yield $43 \%, \mathbf{2 5} / \mathbf{2 6}=3 / 1)$.

Diethyl ((1S,2S)-2-((tert-butyldimethylsilyl)oxy)-1-hydroxypropyl)phosphonate (25). ${ }^{1} \mathrm{H}$ NMR (500 $\left.\mathrm{MHz}, \mathrm{CDCl}_{3}\right) \delta 4.23-4.13(\mathrm{~m}, 5 \mathrm{H}), 3.62-3.58(\mathrm{~m}, 1 \mathrm{H}), 2.80(\mathrm{dd}, J=12.4,6.5 \mathrm{~Hz}, 1 \mathrm{H}), 1.35-1.26$ (m, 9H), $0.90(\mathrm{~s}, 9 \mathrm{H}), 0.11(\mathrm{~d}, J=4.6 \mathrm{~Hz}, 6 \mathrm{H}) .{ }^{13} \mathrm{C} \mathrm{NMR}\left(126 \mathrm{MHz}, \mathrm{CDCl}_{3}\right) \delta 72.57(\mathrm{~d}, J=162.2 \mathrm{~Hz})$, $67.75(\mathrm{~d}, J=4.3 \mathrm{~Hz}), 62.40(\mathrm{dd}, J=49.7,6.9 \mathrm{~Hz}), 25.77,21.23(\mathrm{~d}, J=7.8 \mathrm{~Hz}), 17.99,16.46(\mathrm{dd}, J=5.6$, 2.1 Hz), -4.21, -4.83. ${ }^{31} \mathrm{P}$ NMR (202 MHz, $\left.\mathrm{CDCl}_{3}\right) \delta 22.17$.

Diethyl ((1R,2S)-2-((tert-butyldimethylsilyl)oxy)-1-hydroxypropyl)phosphonate $(26) .{ }^{1} \mathrm{H} \quad \mathrm{NMR}$ $\left(500 \mathrm{MHz}, \mathrm{CDCl}_{3}\right) \delta 4.24-4.10(\mathrm{~m}, 5 \mathrm{H}), 3.92-3.88(\mathrm{~m}, 1 \mathrm{H}), 2.71-2.63(\mathrm{~m}, 1 \mathrm{H}), 1.38-1.26(\mathrm{~m}, 9 \mathrm{H})$, $0.89(\mathrm{~s}, 9 \mathrm{H}), 0.08(\mathrm{~d}, J=2.0 \mathrm{~Hz}, 6 \mathrm{H}) .{ }^{13} \mathrm{C} \mathrm{NMR}\left(126 \mathrm{MHz}, \mathrm{CDCl}_{3}\right) \delta 72.70(\mathrm{~d}, J=159.4 \mathrm{~Hz}), 68.82(\mathrm{~d}$, $J=6.3 \mathrm{~Hz}), 62.49(\mathrm{dd}, J=30.2,6.9 \mathrm{~Hz}), 25.78,18.64(\mathrm{~d}, J=2.7 \mathrm{~Hz}), 18.04,16.47(\mathrm{dd}, J=5.9,2.6 \mathrm{~Hz})$, $-4.52,-4.88 .{ }^{31} \mathrm{P}$ NMR $\left(202 \mathrm{MHz}, \mathrm{CDCl}_{3}\right) \delta 21.79$

Diethyl ((1R,2S)-2-((tert-butyldimethylsilyl)oxy)-1-fluoropropyl)phosphonate (27). To a solution of $25(0.4 \mathrm{~g}, 1.23 \mathrm{mmol})$ in anhydrous DCM $(20 \mathrm{~mL})$, DAST $(1.13 \mathrm{~mL}, 8.58 \mathrm{mmol})$ was dripped in at $-30{ }^{\circ} \mathrm{C}$. The mixture was then warmed to $\mathrm{rt}$ and stirred for $6 \mathrm{~h}$ before being cooled back down to $-30{ }^{\circ} \mathrm{C}$ and quenched with ice-cold water. The aqueous layer was extracted with DCM $(100 \mathrm{~mL} \times 2)$, and the combined organic extracts were subsequently dried over $\mathrm{Na}_{2} \mathrm{SO}_{4}$, and concentrated under reduced pressure. The resultant residue was purified by silica gel column chromatography (hexanes/ethyl acetate $=4 / 1)$ to give fluorinated product, $27(100 \mathrm{mg}, 25 \%)$ as an oil. ${ }^{1} \mathrm{H} \mathrm{NMR}\left(500 \mathrm{MHz}, \mathrm{CDCl}_{3}\right) \delta 4.61$ (ddd, $J=46.0,5.6,3.3 \mathrm{~Hz}, 1 \mathrm{H}), 4.35-4.13(\mathrm{~m}, 5 \mathrm{H}), 1.40-1.32(\mathrm{~m}, 9 \mathrm{H}), 0.89(\mathrm{~s}, 9 \mathrm{H}), 0.09(\mathrm{~d}, J=2.2 \mathrm{~Hz}$, 6H). ${ }^{13} \mathrm{C}$ NMR $\left(126 \mathrm{MHz}, \mathrm{CDCl}_{3}\right) \delta 92.52(\mathrm{dd}, J=187.6,164.3 \mathrm{~Hz}), 67.78(\mathrm{dd}, J=21.2,6.3 \mathrm{~Hz}), 62.84$ $(\mathrm{dd}, J=82.9,6.9 \mathrm{~Hz}), 25.76,18.69(\mathrm{dd}, J=7.4,2.9 \mathrm{~Hz}), 18.09,16.43(\mathrm{t}, J=6.3 \mathrm{~Hz}),-4.64,-4.83 .{ }^{31} \mathrm{P}$ CPD NMR (202 MHz, $\left.\mathrm{CDCl}_{3}\right) \delta 15.87(\mathrm{~d}, J=76.6 \mathrm{~Hz}) .{ }^{19} \mathrm{~F}$ NMR $\left(471 \mathrm{MHz}, \mathrm{CDCl}_{3}\right) \delta-217.06(\mathrm{ddd}, J$ $=76.5,46.0,22.1 \mathrm{~Hz})$

Diethyl ((1R,2S)-1-fluoro-2-hydroxypropyl)phosphonate (28). To a solution of 27 (50 mg, $0.15 \mathrm{mmol})$ in THF $(10 \mathrm{~mL})$ was added TBAF $(304 \mu \mathrm{L}, 1 \mathrm{M}$ in THF). The mixture was stirred at $\mathrm{rt}$ for $3 \mathrm{~h}$ and concentrated in vacuo before being purified by silica gel column chromatography $(\mathrm{DCM} /$ acetone $=4 / 1)$ to give $28(25 \mathrm{mg}, 76 \%) .{ }^{1} \mathrm{H}$ NMR $\left(500 \mathrm{MHz}, \mathrm{CDCl}_{3}\right) \delta 4.48(\mathrm{ddd}, J=45.9,7.0,2.5 \mathrm{~Hz}, 1 \mathrm{H}), 4.29-4.14$ 
$(\mathrm{m}, 5 \mathrm{H}), 3.19(\mathrm{~d}, J=3.8 \mathrm{~Hz}, 1 \mathrm{H}), 1.37(\mathrm{td}, J=7.2,2.2 \mathrm{~Hz}, 9 \mathrm{H}) .{ }^{13} \mathrm{C} \mathrm{NMR}\left(126 \mathrm{MHz}, \mathrm{CDCl}_{3}\right) \delta 90.61$ (dd, $J=188.9,162.2 \mathrm{~Hz}), 66.13(\mathrm{dd}, J=21.4,2.1 \mathrm{~Hz}), 63.42(\mathrm{dd}, J=98.8,6.8 \mathrm{~Hz}), 18.70(\mathrm{dd}, J=9.0$, 4.6 Hz), $16.42(\mathrm{dd}, J=8.7,5.6 \mathrm{~Hz}) .{ }^{31} \mathrm{P} \mathrm{NMR}\left(202 \mathrm{MHz}, \mathrm{CDCl}_{3}\right) \delta 17.09(\mathrm{~d}, J=72.3 \mathrm{~Hz}) .{ }^{19} \mathrm{~F} \mathrm{NMR}(471$ $\left.\mathrm{MHz}, \mathrm{CDCl}_{3}\right) \delta-212.05(\mathrm{ddd}, J=72.1,46.2,10.9 \mathrm{~Hz})$.

((1R,2S)-1-fluoro-2-hydroxypropyl)phosphonate (1h). To a solution of 28 (20 mg, $0.094 \mathrm{mmol})$ in DCM $(10 \mathrm{~mL})$ was added TMSBr $(500 \mu \mathrm{L})$ and allylTMS $(300 \mu \mathrm{L})$. The mixture was stirred at $\mathrm{rt}$ overnight, and the solvent removed in vacuo. The concentrated product was neutralized by addition of aqueous $\mathrm{NH}_{4} \mathrm{HCO}_{3}$ and washed with $\mathrm{CHCl}_{3}$. The aqueous layer was then separated, concentrated, and purified by a P2 column to give $\mathbf{1 h}(15 \mathrm{mg}, 84 \%) .{ }^{1} \mathrm{H}$ NMR $\left(500 \mathrm{MHz}, \mathrm{D}_{2} \mathrm{O}\right) \delta 4.52$ (ddd, $J=47.1,6.5$, $3.5 \mathrm{~Hz}, 1 \mathrm{H}), 4.25-4.07(\mathrm{~m}, 1 \mathrm{H}), 1.30(\mathrm{dd}, J=6.5,1.3 \mathrm{~Hz}, 3 \mathrm{H}) .{ }^{13} \mathrm{C} \mathrm{NMR}\left(126 \mathrm{MHz}, \mathrm{D}_{2} \mathrm{O}\right) \delta 95.05(\mathrm{dd}$, $J=178.8,147.7 \mathrm{~Hz}), 67.37(\mathrm{dd}, J=20.3,6.5 \mathrm{~Hz}), 16.58(\mathrm{dd}, J=6.4,2.7 \mathrm{~Hz}) .{ }^{19} \mathrm{~F}$ NMR $(471 \mathrm{MHz}, 100$ $\mathrm{mM} \mathrm{NaOD}$ in $\left.\mathrm{D}_{2} \mathrm{O}\right) \delta-215.70$ (ddd, $\left.J=62.1,46.7,23.5 \mathrm{~Hz}\right) .{ }^{31} \mathrm{P}$ NMR $(202 \mathrm{MHz}, 100 \mathrm{mM} \mathrm{NaOD}$ in $\left.\mathrm{D}_{2} \mathrm{O}\right) \delta 9.57\left(\mathrm{ddd}, J=62.2,6.1,6.1 \mathrm{~Hz}\right.$ ). HRMS (ESI): calcd for $\mathrm{C}_{3} \mathrm{H}_{7} \mathrm{FO}_{4} \mathrm{P}\left(\mathrm{M}-\mathrm{H}^{-}\right)$157.0071, found 157.0078 .

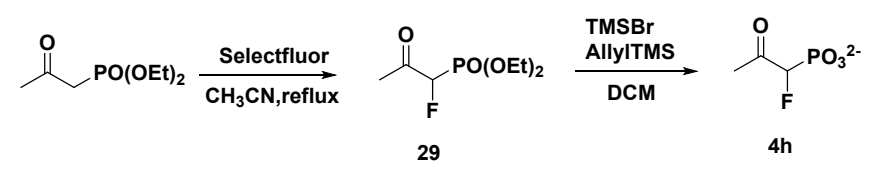

Diethyl (1-fluoro-2-oxopropyl)phosphonate (29). To a stirred solution of the $\beta$-ketophosphonate $(1 \mathrm{~g}$, $5.15 \mathrm{mmol})$ in dry acetonitrile $(20 \mathrm{~mL})$ was added Selectfluor $(3.5 \mathrm{~g}, 2.0 \mathrm{mmol})$ at $\mathrm{rt}$. The mixture was heated to reflux for $24 \mathrm{~h}$. The reaction solution was cooled back to rt, and EtOAc $(30 \mathrm{~mL})$ and saturated aqueous $\mathrm{NH}_{4} \mathrm{Cl}(20 \mathrm{~mL})$ were added in succession. The layers were then separated, and the organic layer was washed with brine $(2 \times 15 \mathrm{~mL})$ before being concentrated and purified by column chromatography (hexanes/EtOAc $=4 / 1)$ to afford $29(0.3 \mathrm{~g}$, yield $27 \%) .{ }^{1} \mathrm{H}$ NMR $\left(500 \mathrm{MHz}, \mathrm{CDCl}_{3}\right) \delta 5.10(\mathrm{dd}, J=47.9$, $14.3 \mathrm{~Hz}, 1 \mathrm{H}), 4.23-4.09(\mathrm{~m}, 4 \mathrm{H}), 2.30(\mathrm{~d}, J=4.3 \mathrm{~Hz}, 3 \mathrm{H}), 1.33-1.26(\mathrm{~m}, 6 \mathrm{H}) .{ }^{13} \mathrm{C} \mathrm{NMR}(126 \mathrm{MHz}$, $\left.\mathrm{CDCl}_{3}\right) \delta 200.56(\mathrm{~d}, J=20.3 \mathrm{~Hz}), 91.60(\mathrm{dd}, J=197.5,152.6 \mathrm{~Hz}), 64.15(\mathrm{t}, J=6.3 \mathrm{~Hz}), 26.72,16.26$ $(\mathrm{dd}, J=5.9,2.6 \mathrm{~Hz}) .{ }^{19} \mathrm{~F} \mathrm{NMR}\left(471 \mathrm{MHz}, \mathrm{CDCl}_{3}\right) \delta-207.25--207.73(\mathrm{~m})$.

(1-fluoro-2-oxopropyl)phosphonate (4h). ${ }^{1} \mathrm{H} \mathrm{NMR}\left(500 \mathrm{MHz}, \mathrm{D}_{2} \mathrm{O}\right) \delta 5.23(\mathrm{dd}, J=48.2,14.0 \mathrm{~Hz}, 1 \mathrm{H})$, $2.28(\mathrm{~d}, J=3.0 \mathrm{~Hz}, 3 \mathrm{H}) .{ }^{13} \mathrm{C} \mathrm{NMR}\left(126 \mathrm{MHz}, \mathrm{D}_{2} \mathrm{O}\right) \delta 208.92(\mathrm{~d}, J=15.4 \mathrm{~Hz}), 96.88(\mathrm{dd}, J=187.6$, 
125.3 Hz), 26.31. ${ }^{31} \mathrm{P}$ NMR $\left(202 \mathrm{MHz}, \mathrm{D}_{2} \mathrm{O}\right) \delta 4.95(\mathrm{dd}, J=58.6,14.0 \mathrm{~Hz}) .{ }^{19} \mathrm{~F}$ NMR $\left(471 \mathrm{MHz}, \mathrm{D}_{2} \mathrm{O}\right)$ $\delta-201.02--201.35$ (ddd, $J=59.8,48.3,3.9 \mathrm{~Hz}$ ). HRMS (ESI): calcd for $\mathrm{C}_{3} \mathrm{H}_{5} \mathrm{FO}_{4} \mathrm{P}\left(\mathrm{M}-\mathrm{H}^{-}\right)$154.9915, found 154.9921.

Table S11. Assignment of the chemical shift and corresponding coupling constant of compounds 1-4, 1a-3a, 1b-3b, 1c-4c, and 1f-4f.

$$
\begin{array}{ll}
\mathrm{F}_{\mathrm{n}} \mathrm{H}_{3-\mathrm{n}} \mathrm{C}^{3} & \mathrm{R}^{1}=\mathrm{H}, \mathrm{F}
\end{array}
$$

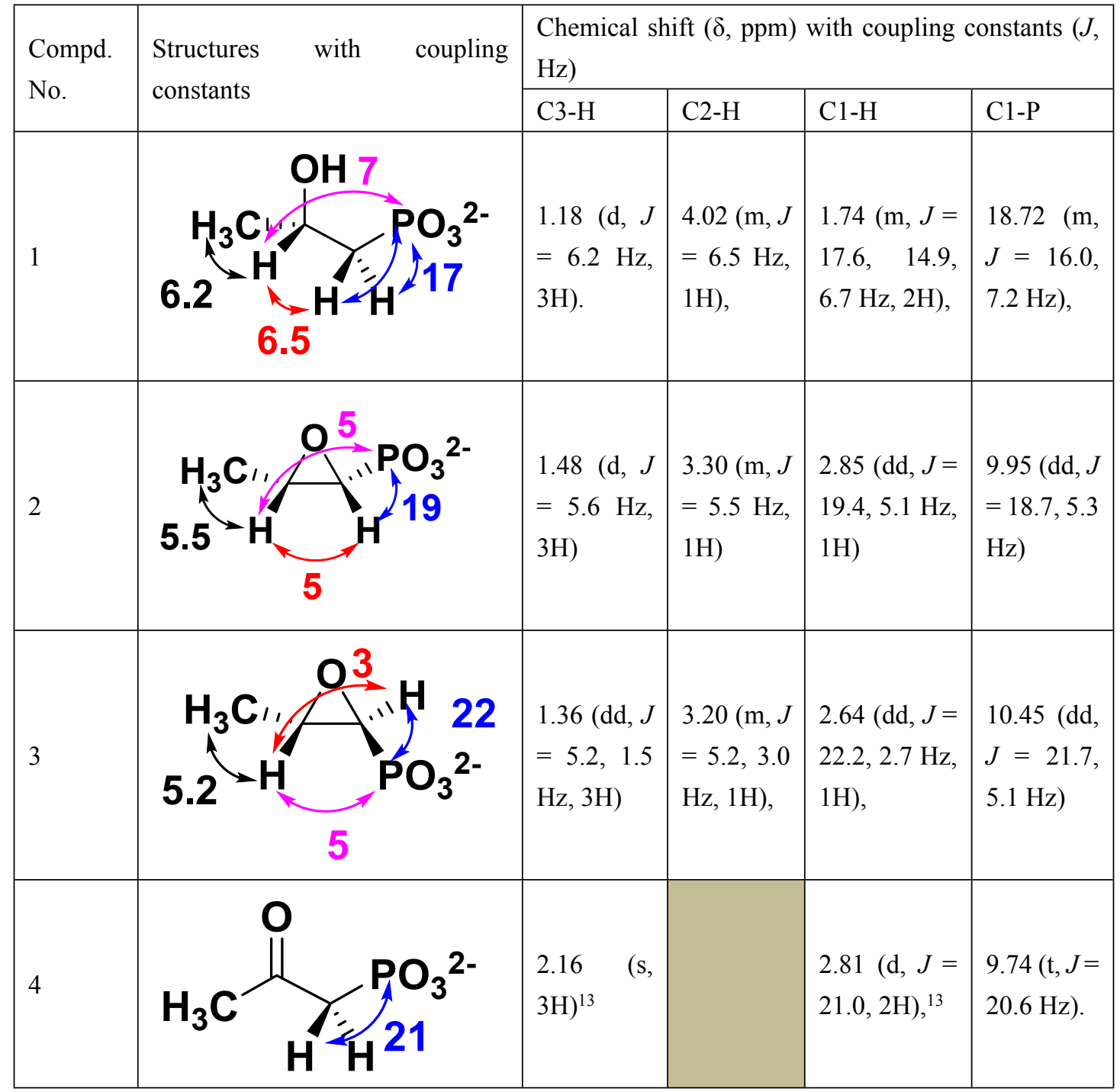




\begin{tabular}{|c|c|c|c|c|c|c|}
\hline \multirow{2}{*}{$\begin{array}{l}\text { Compd. } \\
\text { No. }\end{array}$} & \multirow{2}{*}{ Structures with coupling constants } & \multicolumn{5}{|c|}{$\begin{array}{l}\text { Chemical shift }(\delta, \text { ppm) with coupling constants }(J, \\
\mathrm{Hz})\end{array}$} \\
\hline & & $\mathrm{C} 3-\mathrm{F}$ & $\mathrm{C} 3-\mathrm{H}_{2}$ & $\begin{array}{l}\mathrm{C} 2- \\
\mathrm{H}\end{array}$ & $\mathrm{C} 1-\mathrm{H}$ & $\mathrm{C} 1-\mathrm{P}$ \\
\hline $1 \mathrm{a}$ & $\mathrm{PO}_{3}^{2}$ & $\begin{array}{l}-225.09 \\
- \\
225.44 \\
(\mathrm{~m}, J= \\
48.5, \\
20.6, \\
3.3 \mathrm{~Hz}),\end{array}$ & $\begin{array}{l}4.49(\mathrm{ddd}, J \\
=46.9,10.0, \\
2.5 \mathrm{~Hz}, 1 \mathrm{H}), \\
4.30(\mathrm{ddd}, J \\
=47.8,9.9, \\
6.5 \mathrm{~Hz}, 1 \mathrm{H})\end{array}$ & $\begin{array}{l}4.16 \\
- \\
4.01 \\
(\mathrm{~m}, \\
1 \mathrm{H}),\end{array}$ & $\begin{array}{l}1.76- \\
1.56 \\
(\mathrm{~m}, \\
2 \mathrm{H}) .\end{array}$ & $\begin{array}{l}17.39 \\
(\mathrm{~m}, \quad J \\
= \\
16.3, \\
8.3, \\
2.5 \\
\mathrm{~Hz})\end{array}$ \\
\hline $2 a$ & 5.6 & $\begin{array}{l}-222.34 \\
(\mathrm{~m}, J= \\
47.7, \\
12.0, \\
2.8 \mathrm{~Hz}),\end{array}$ & $\begin{array}{l}4.95-4.82 \\
(\mathrm{~m}, \quad 47.8, \\
11.1,2.0 \mathrm{~Hz}, \\
2 \mathrm{H}),\end{array}$ & $\begin{array}{l}3.51 \\
- \\
3.44 \\
(\mathrm{~m}, \\
1 \mathrm{H}),\end{array}$ & $\begin{array}{l}2.98 \\
\text { (ddd, } \\
J \quad= \\
18.4, \\
5.6, \\
2.4 \\
\mathrm{~Hz}, \\
1 \mathrm{H})\end{array}$ & $\begin{array}{l}8.25 \\
(\mathrm{ddd}, \\
J= \\
18.6, \\
4.5, \\
2.5 \\
\mathrm{~Hz})\end{array}$ \\
\hline $3 a$ & $\begin{array}{l}20 \\
2-\end{array}$ & $\begin{array}{l}-225.58 \\
(\mathrm{~m}, J= \\
47.6, \\
13.7, \\
4.5 \mathrm{~Hz}) .\end{array}$ & $\begin{array}{l}4.92-4.80 \\
(\mathrm{~m}, \quad 2 \mathrm{H}, \\
\text { overlapped })\end{array}$ & $\begin{array}{l}3.45 \\
- \\
3.40 \\
(\mathrm{~m})\end{array}$ & $\begin{array}{l}2.81 \\
\text { (ddd, } \\
J= \\
20.8, \\
3.1, \\
1.4 \\
\mathrm{~Hz}, \\
1 \mathrm{H})\end{array}$ & $\begin{array}{l}9.10 \\
(\mathrm{ddd}, \\
J= \\
20.2, \\
5.0, \\
5.0 \\
\mathrm{~Hz})\end{array}$ \\
\hline
\end{tabular}




\begin{tabular}{|c|c|c|c|c|c|c|}
\hline \multirow{2}{*}{$\begin{array}{l}\text { Compd. } \\
\text { No. }\end{array}$} & \multirow{2}{*}{$\begin{array}{l}\text { Structures with coupling } \\
\text { constants }\end{array}$} & \multicolumn{5}{|c|}{ Chemical shift $(\delta, \mathrm{ppm})$ with coupling constants $(J, \mathrm{~Hz})$} \\
\hline & & C3-F & C3-H & $\mathrm{C} 2-\mathrm{H}$ & $\mathrm{C} 1-\mathrm{H}$ & C1-P \\
\hline $1 b$ & 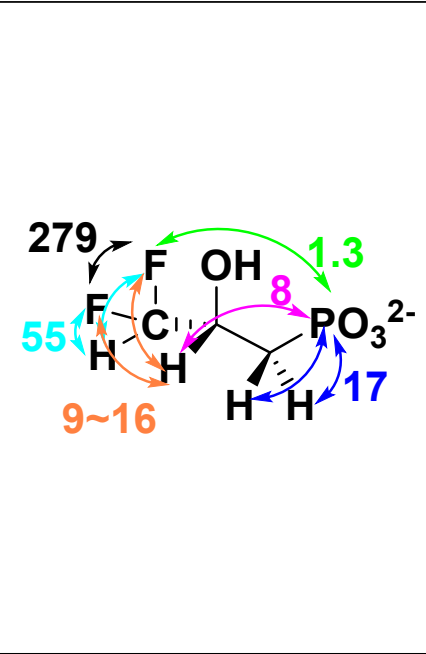 & $\begin{array}{l}-129.12 \\
\text { (ddd, J } \\
=279.5, \\
55.0, \\
9.0 \mathrm{~Hz}), \\
- \\
134.11 \\
\text { (ddd, J } \\
=279.7, \\
55.2, \\
16.1 \\
\mathrm{~Hz}) .\end{array}$ & $\begin{array}{l}5.91(\mathrm{~m}, J= \\
55.2, \quad 2.4 \\
\mathrm{~Hz}, 1 \mathrm{H}),\end{array}$ & $\begin{array}{l}4.20-4.03 \\
(\mathrm{~m}, 1 \mathrm{H}),\end{array}$ & $\begin{array}{l}2.03- \\
1.79 \\
(\mathrm{~m}, \\
2 \mathrm{H}) .\end{array}$ & 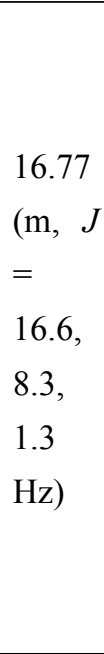 \\
\hline $2 b$ & (310 & $\begin{array}{l}-118.26 \\
\text { (ddd, } J \\
=310.4, \\
57.7, \\
7.4 \mathrm{~Hz}), \\
-121.20 \\
(\mathrm{dd}, J= \\
310.4, \\
52.9 \\
\mathrm{~Hz}) .\end{array}$ & $\begin{array}{l}6.25(\mathrm{ddd}, J \\
=57.8,52.9, \\
7.0 \mathrm{~Hz}, 1 \mathrm{H}),\end{array}$ & $\begin{array}{l}3.44(\mathrm{~m}, J= \\
6.0 \mathrm{~Hz}, 1 \mathrm{H})\end{array}$ & $\begin{array}{l}3.00 \\
\text { (ddd, } J \\
=18.7, \\
4.8,2.6 \\
\mathrm{~Hz}, \\
1 \mathrm{H})\end{array}$ & $\begin{array}{l}7.09 \\
(J= \\
\mathrm{m}, \\
17.1, \\
3.8, \\
2.0 \\
\mathrm{~Hz})\end{array}$ \\
\hline $3 b$ & (296) & $\begin{array}{l}-123.94 \\
\text { (ddd, } J \\
=295.6, \\
54.6, \\
4.7 \mathrm{~Hz} \text { ), } \\
- \\
125.36 \\
(\mathrm{ddd}, \quad J \\
=295.8, \\
55.2, \\
9.4 \mathrm{~Hz}) .\end{array}$ & $\begin{array}{lr}6.30 & -6.10 \\
(\mathrm{~m}, & 1 \mathrm{H}, \\
\text { overlapped })\end{array}$ & $\begin{array}{lr}3.46 & -3.42 \\
(\mathrm{~m}, & 1 \mathrm{H}, \\
\text { overlapped })\end{array}$ & $\begin{array}{c}3.14- \\
3.12 \\
(\mathrm{~m}, \\
1 \mathrm{H} \\
2.6 \\
\mathrm{~Hz})\end{array}$ & $\begin{array}{l}7.78 \\
(J= \\
\mathrm{m}, \\
20.1, \\
4.9, \\
2.6 \\
\mathrm{~Hz})\end{array}$ \\
\hline
\end{tabular}




\begin{tabular}{|c|c|c|c|c|c|}
\hline \multirow{2}{*}{$\begin{array}{l}\text { Compd. } \\
\text { No. }\end{array}$} & \multirow{2}{*}{$\begin{array}{l}\text { Structures with coupling } \\
\text { constants }\end{array}$} & \multicolumn{4}{|c|}{$\begin{array}{l}\text { Chemical shift }(\delta, \text { ppm) with coupling constants }(J, \\
\mathrm{Hz})\end{array}$} \\
\hline & & C3-F & $\mathrm{C} 2-\mathrm{H}$ & $\mathrm{C} 1-\mathrm{H}$ & C1-P \\
\hline $1 \mathrm{c}$ & $\mathrm{F}-\mathrm{FH}^{\mathrm{OH}} 8$ & $\begin{array}{l}-80.32(\mathrm{~d}, \\
J=6.8 \\
\mathrm{~Hz}) .\end{array}$ & $\begin{array}{l}4.32- \\
4.10(\mathrm{~m}, \\
1 \mathrm{H}),\end{array}$ & $\begin{array}{l}1.88-1.56 \\
(\mathrm{~m}, 2 \mathrm{H}) .\end{array}$ & $\begin{array}{l}16.59(\mathrm{~m}, J \\
=16.6,8.1 \\
\mathrm{~Hz}) .\end{array}$ \\
\hline $2 c$ & 6.7 & $\begin{array}{l}-67.17(\mathrm{~d}, \\
J=6.3 \\
\mathrm{~Hz}),\end{array}$ & $\begin{array}{l}3.68- \\
3.61(\mathrm{~m}, \\
1 \mathrm{H}),\end{array}$ & $\begin{array}{l}3.02(\mathrm{~m}, J= \\
15.6,4.9,1.0 \\
\mathrm{~Hz}, 1 \mathrm{H}) .\end{array}$ & $\begin{array}{l}5.29(\mathrm{dd}, J \\
=15.9,3.4 \\
\mathrm{~Hz}) .\end{array}$ \\
\hline $3 c$ & 4.3 & $\begin{array}{l}-74.11(\mathrm{~d}, \\
J=5.0 \\
\mathrm{~Hz}),\end{array}$ & $\begin{array}{l}3.68- \\
3.61(\mathrm{~m}, \\
1 \mathrm{H}),\end{array}$ & $\begin{array}{l}3.08(\mathrm{dd}, J= \\
20.0,2.7 \mathrm{~Hz}, \\
1 \mathrm{H}),\end{array}$ & $\begin{array}{l}6.76(\mathrm{dd}, J \\
=19.9,4.3 \\
\mathrm{~Hz}),\end{array}$ \\
\hline $4 c$ & & $-87.28(\mathrm{~s})$ & & $\begin{array}{l}2.02(\mathrm{~d}, J= \\
17.2,2 \mathrm{H})\end{array}$ & $\begin{array}{l}16.02(\mathrm{~d}, J \\
=18.0 \mathrm{~Hz})\end{array}$ \\
\hline
\end{tabular}




\begin{tabular}{|c|c|c|c|c|c|c|}
\hline \multirow{2}{*}{$\begin{array}{l}\text { Compd. } \\
\text { No. }\end{array}$} & \multirow{2}{*}{$\begin{array}{l}\text { Structures with coupling } \\
\text { constants }\end{array}$} & \multicolumn{5}{|c|}{ Chemical shift $(\delta, \mathrm{ppm})$ with coupling constants $(J, \mathrm{~Hz})$} \\
\hline & & $\mathrm{C} 3-\mathrm{H}$ & $\mathrm{C} 2-\mathrm{H}$ & $\mathrm{C} 1-\mathrm{H}$ & $\mathrm{C} 1-\mathrm{P}$ & $\mathrm{C} 1-\mathrm{F}$ \\
\hline $1 \mathrm{~h}$ & 6 & $\begin{array}{l}1.30 \\
(\mathrm{dd}, \quad J \\
=6.5, \\
1.3 \mathrm{~Hz}, \\
3 \mathrm{H}) .\end{array}$ & $\begin{array}{l}4.26- \\
4.09 \\
(\mathrm{~m}, J= \\
25,6.5 \\
\mathrm{~Hz}, \\
1 \mathrm{H}),\end{array}$ & $\begin{array}{l}4.52 \\
\text { (ddd, J } \\
=47.1, \\
6.5, \quad 3.5 \\
\mathrm{~Hz}, 1 \mathrm{H}),\end{array}$ & $\begin{array}{l}9.57 \\
\text { (ddd, } J= \\
62.3, \\
6.1, \quad 6.1 \\
\mathrm{~Hz})\end{array}$ & $\begin{array}{l}-215.70 \\
(\mathrm{~m}, \quad J= \\
62.4, \quad 47.2, \\
24.2, \quad 2.5 \\
\mathrm{~Hz})\end{array}$ \\
\hline $2 \mathrm{~h}$ & 8 & & & & $\begin{array}{l}2.56(\mathrm{~d}, \\
J=98.6 \\
<1 \mathrm{~Hz})\end{array}$ & $\begin{array}{l}-137.12 \\
(\mathrm{~m}, J= \\
98.3, \quad 4.2, \\
2.1 \mathrm{~Hz}),\end{array}$ \\
\hline $3 \mathrm{~h}$ & 1.2 & & & & $\begin{array}{l}3.48(\mathrm{~m}, \\
J \quad= \\
102.1, \\
1.2, \quad 1.2 \\
\mathrm{~Hz})\end{array}$ & $\begin{array}{l}-159.24(\mathrm{~d}, \\
J=102.5 \\
1.5 .1 .5 \mathrm{~Hz})\end{array}$ \\
\hline $4 \mathrm{~h}$ & $3.5 \underbrace{\mathbf{4}}_{48}$ & $\begin{array}{l}2.28 \\
(\mathrm{~d}, J= \\
3.0 \mathrm{~Hz}, \\
3 \mathrm{H}) .\end{array}$ & & $\begin{array}{l}5.23 \\
(\mathrm{dd}, J= \\
48.2, \\
14.0 \mathrm{~Hz}, \\
1 \mathrm{H}),\end{array}$ & $\begin{array}{l}4.95(\mathrm{dd}, \\
J=58.6, \\
14.0 \\
\mathrm{~Hz})\end{array}$ & $\begin{array}{l}-201.02- \\
201.35 \\
(\mathrm{ddd}, J= \\
59.8,48.3, \\
3.9 \mathrm{~Hz})\end{array}$ \\
\hline
\end{tabular}


7. Copies of NMR and HRMS spectra

(S)-(2-hydroxypropyl)phosphonate (1)
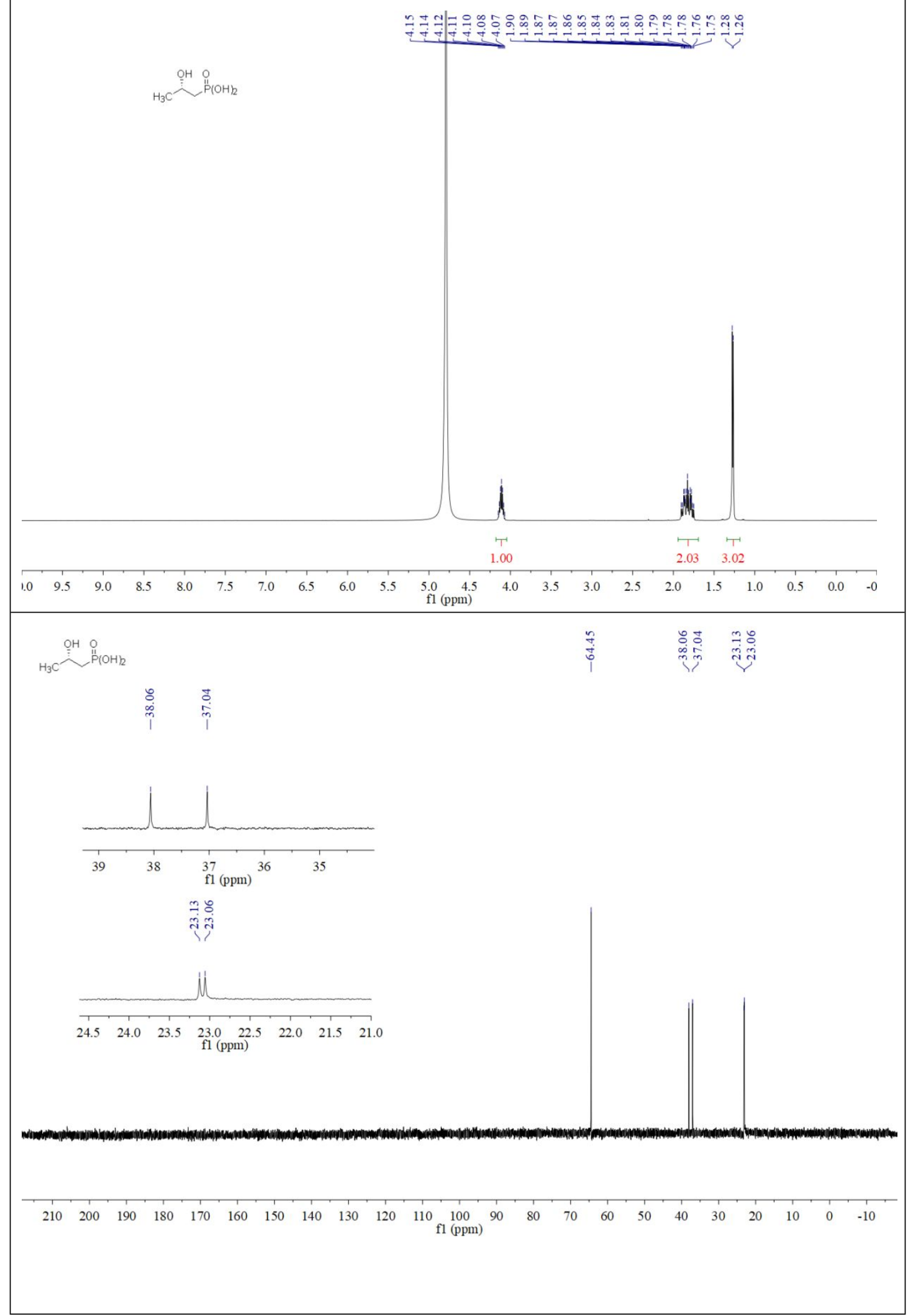


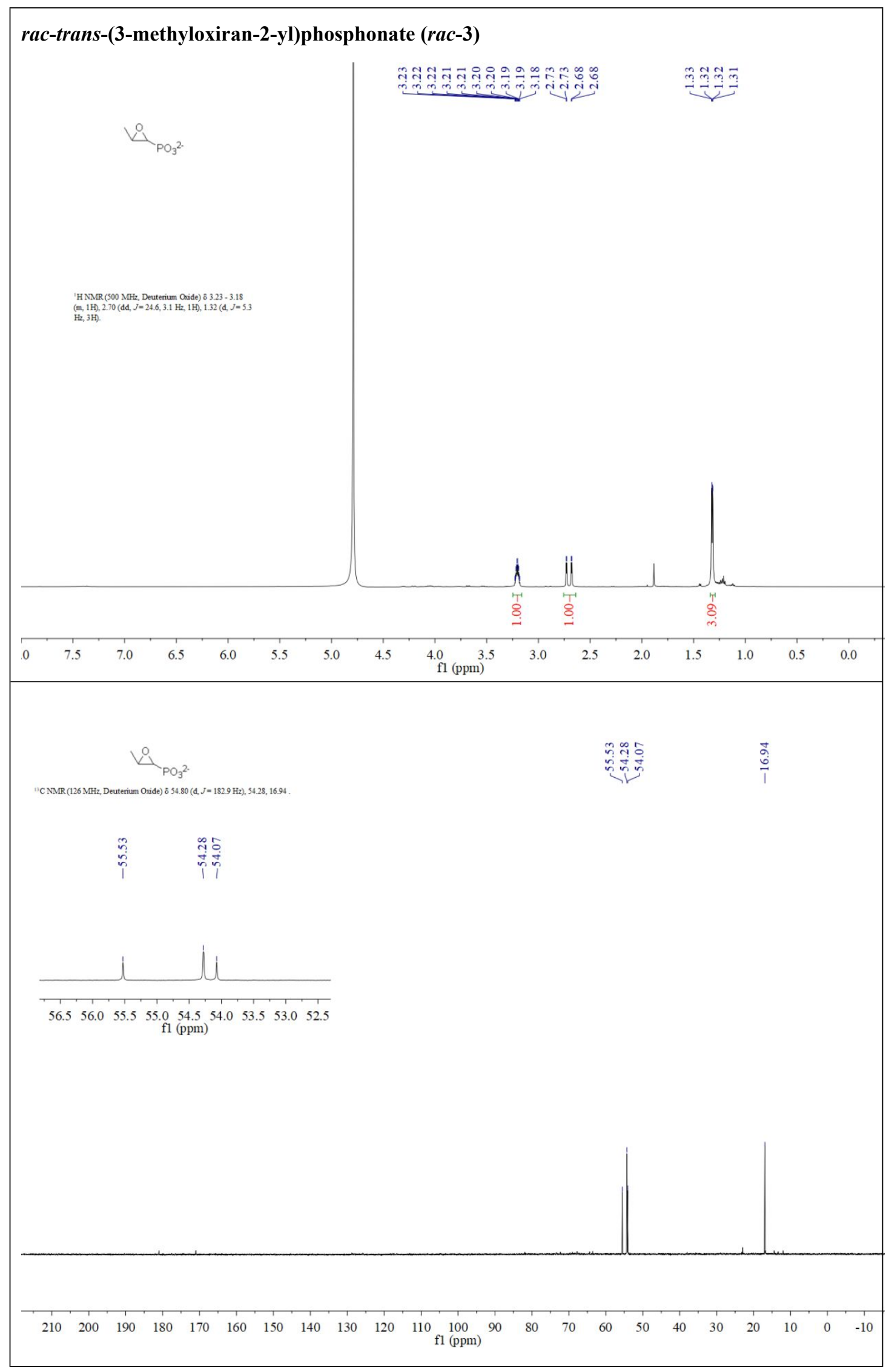




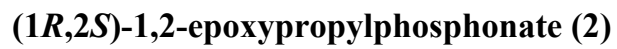
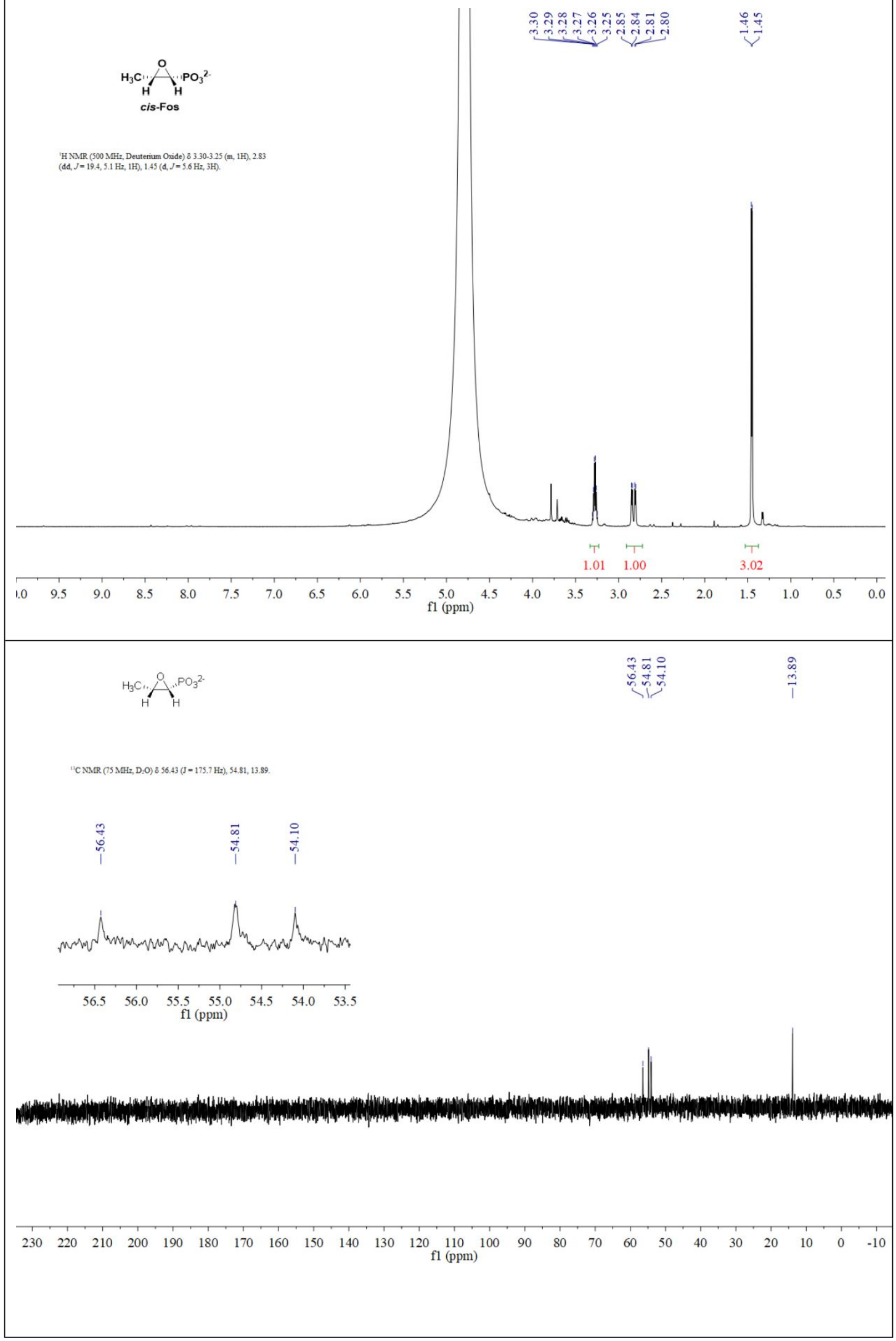

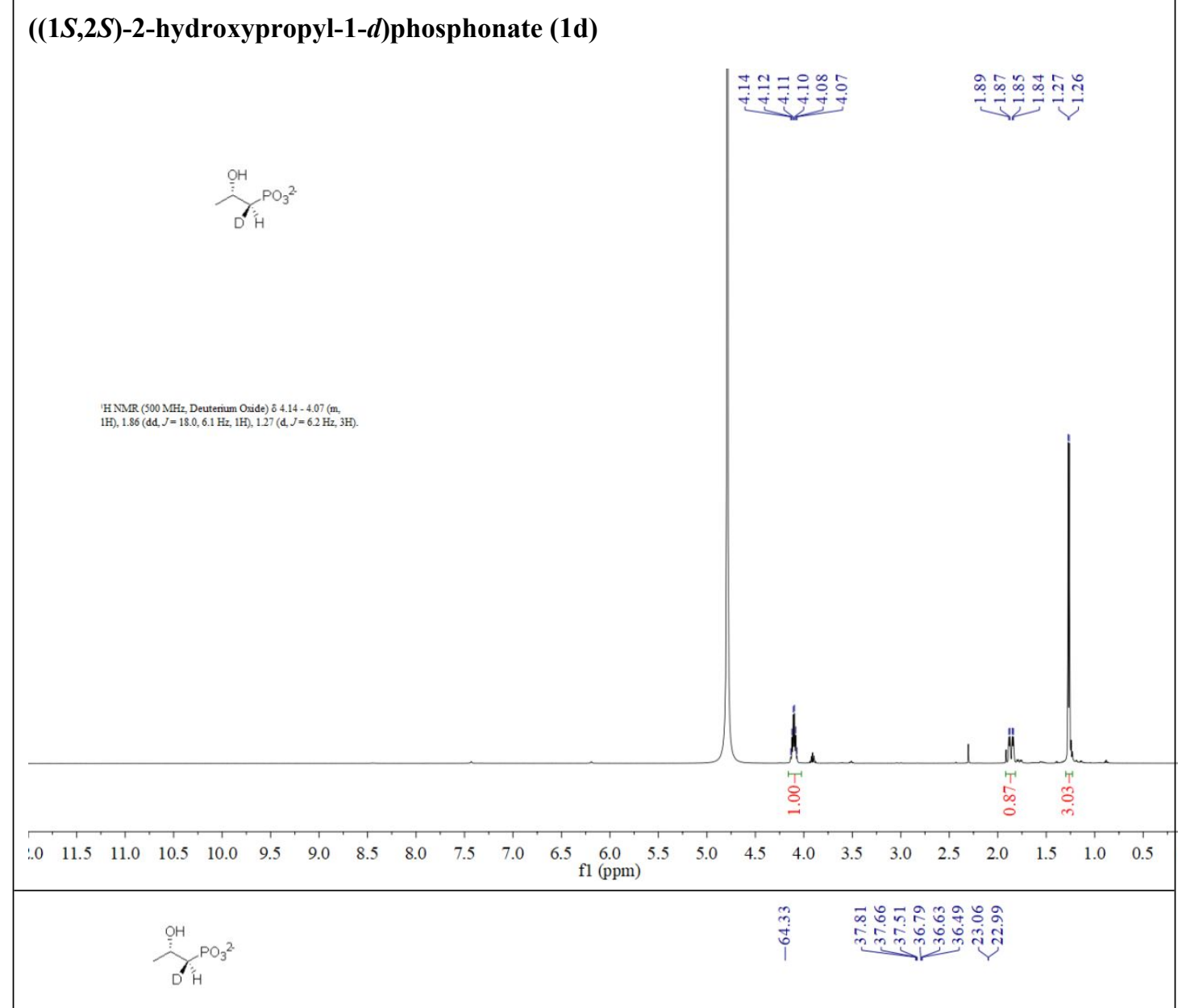

"C NMR (126 MHz, Deutenium Oxide) $564.33,37.15$ (dt, $J=129.0,18.8 \mathrm{~Hz}), 23.03$ (d, $J=8.4 \mathrm{~Hz})$.
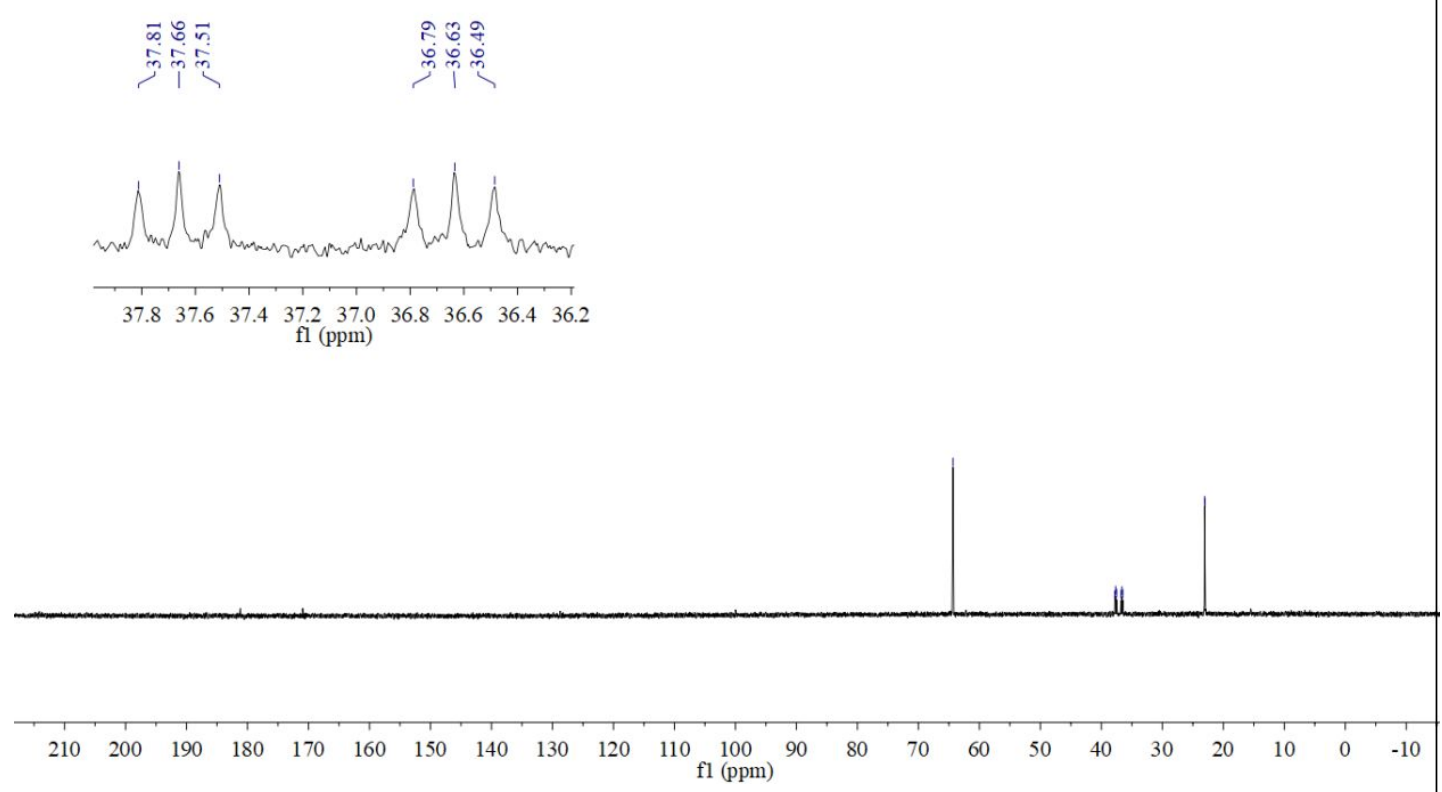

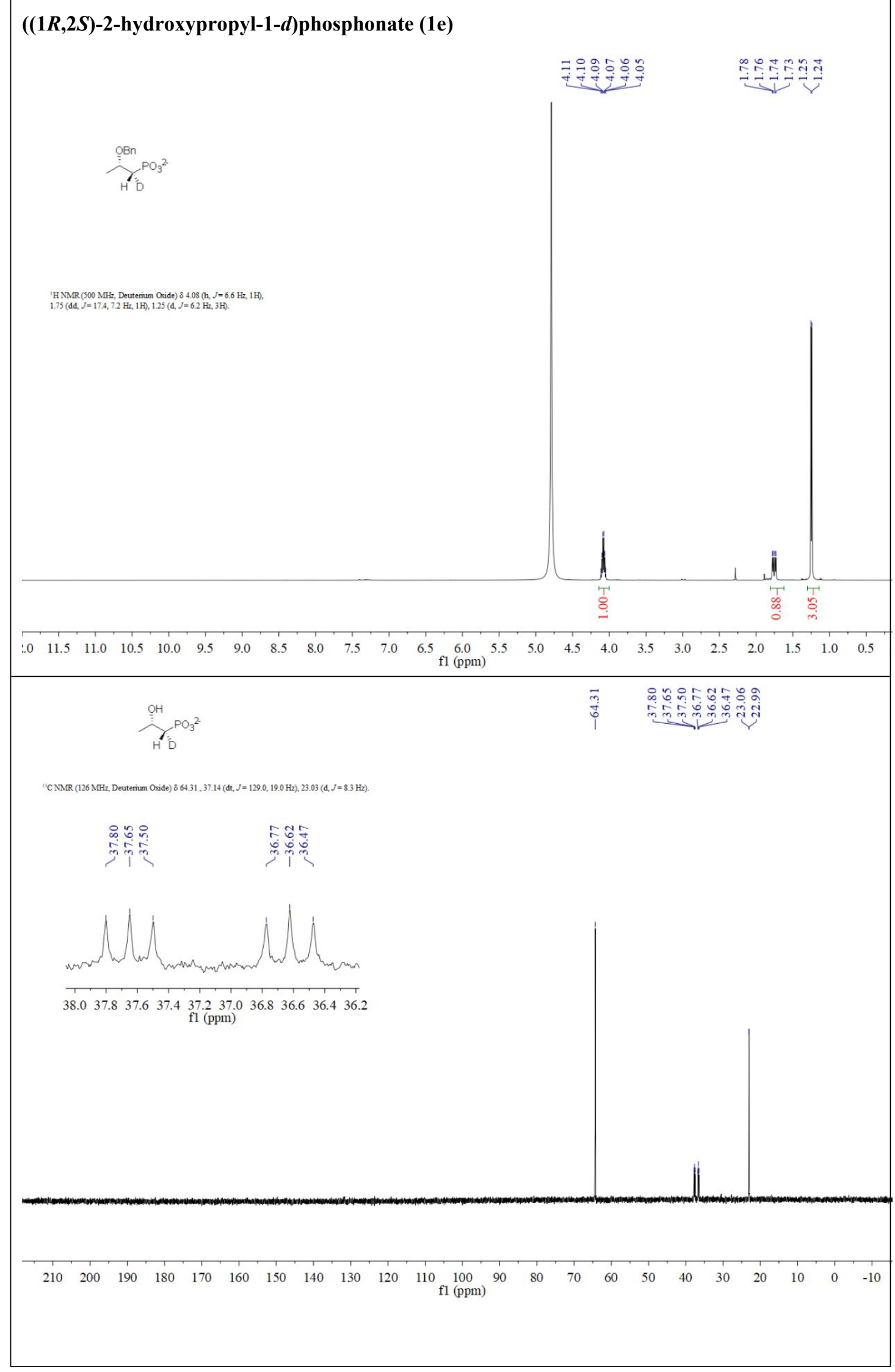

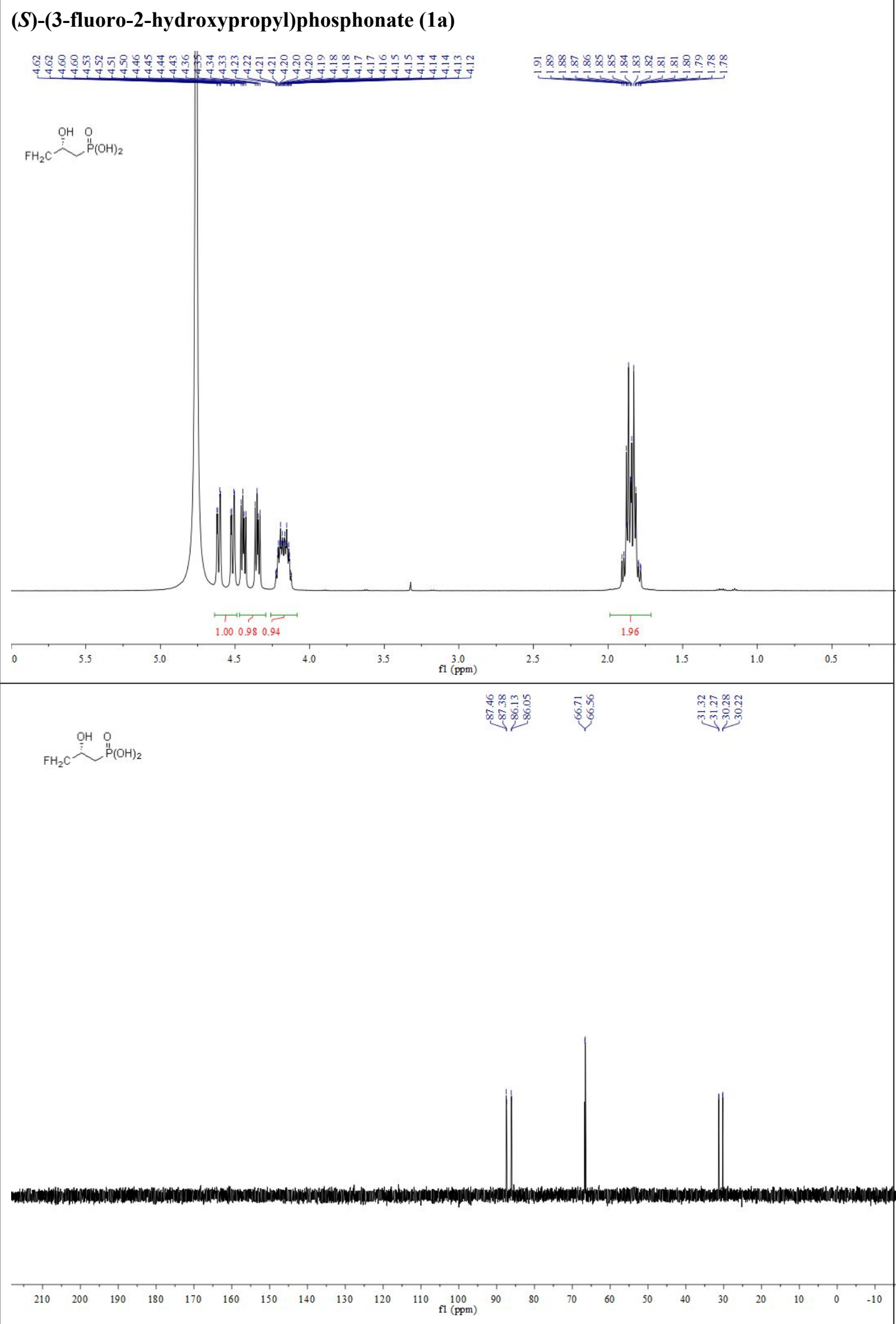
(1R,2S)-1,2-epoxy-3-fluoropropylphosphonate (2a)

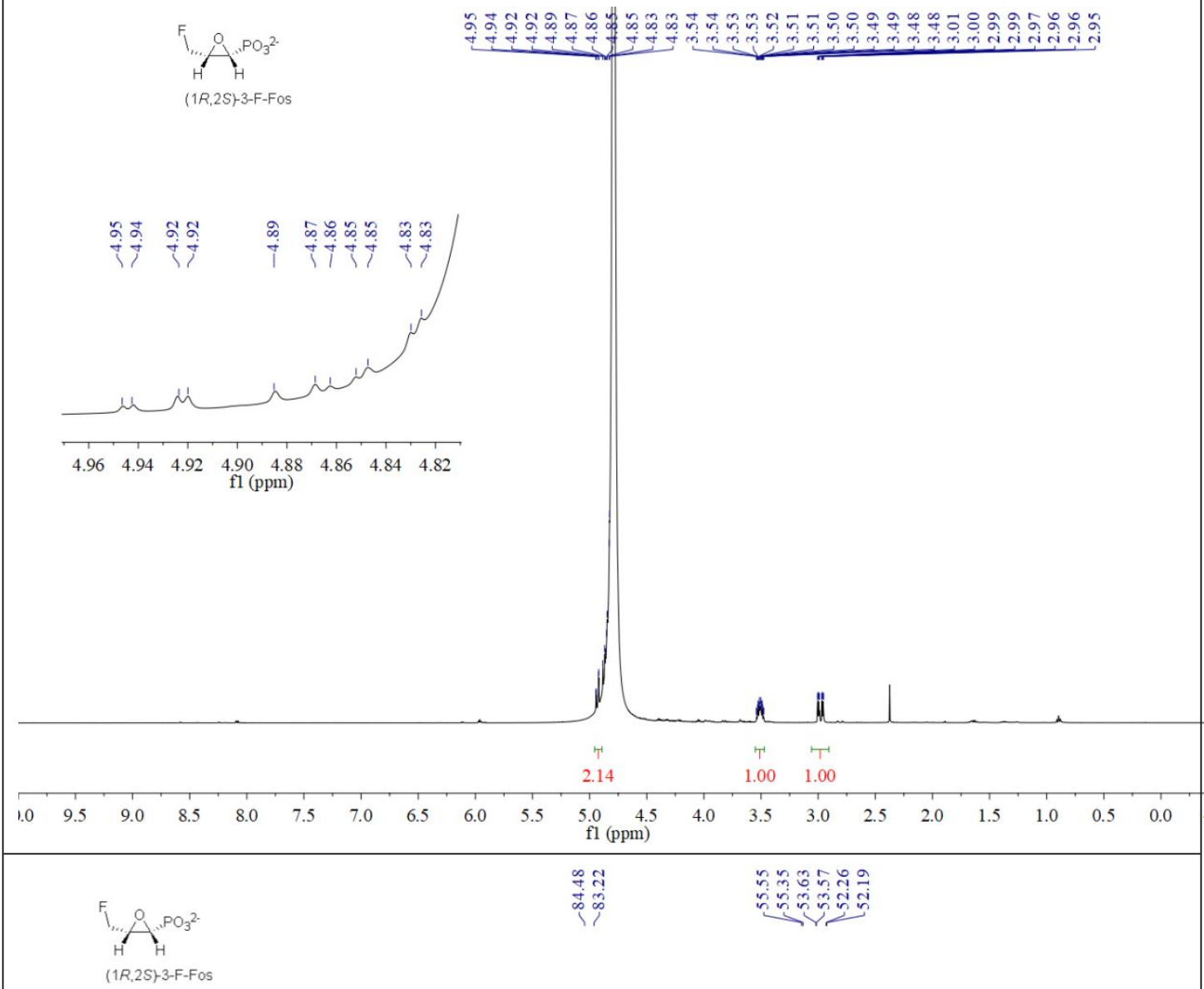

$(1 R, 2 S)-3-F-F o s$

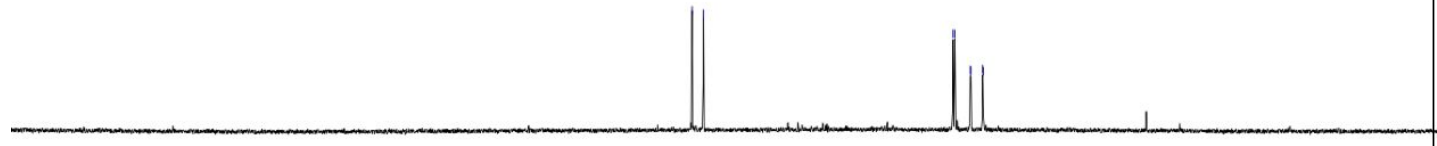

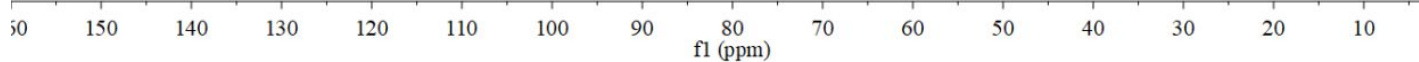



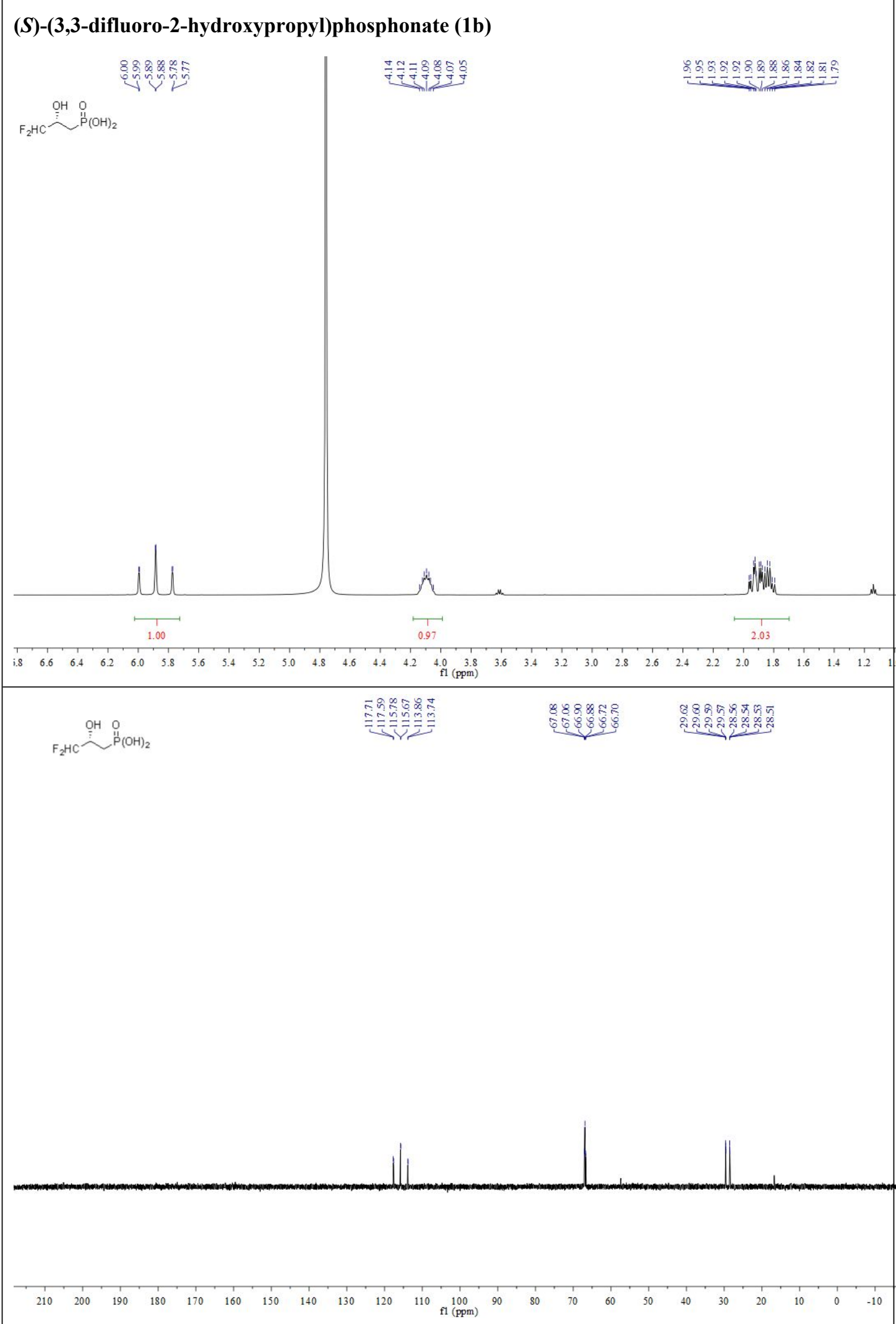

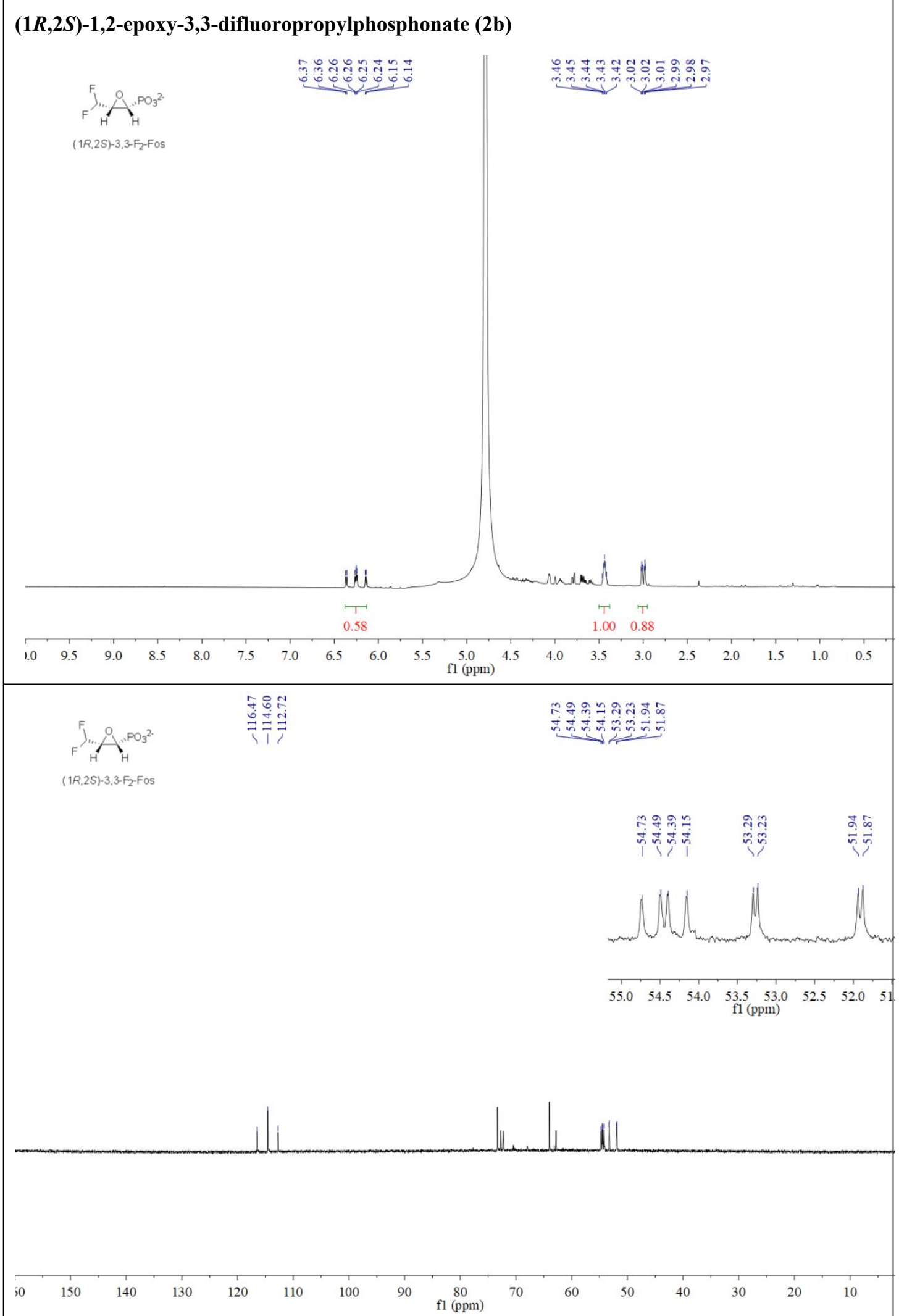
(S)-(3,3,3-trifluoro-2-hydroxypropyl)phosphonate (1c)
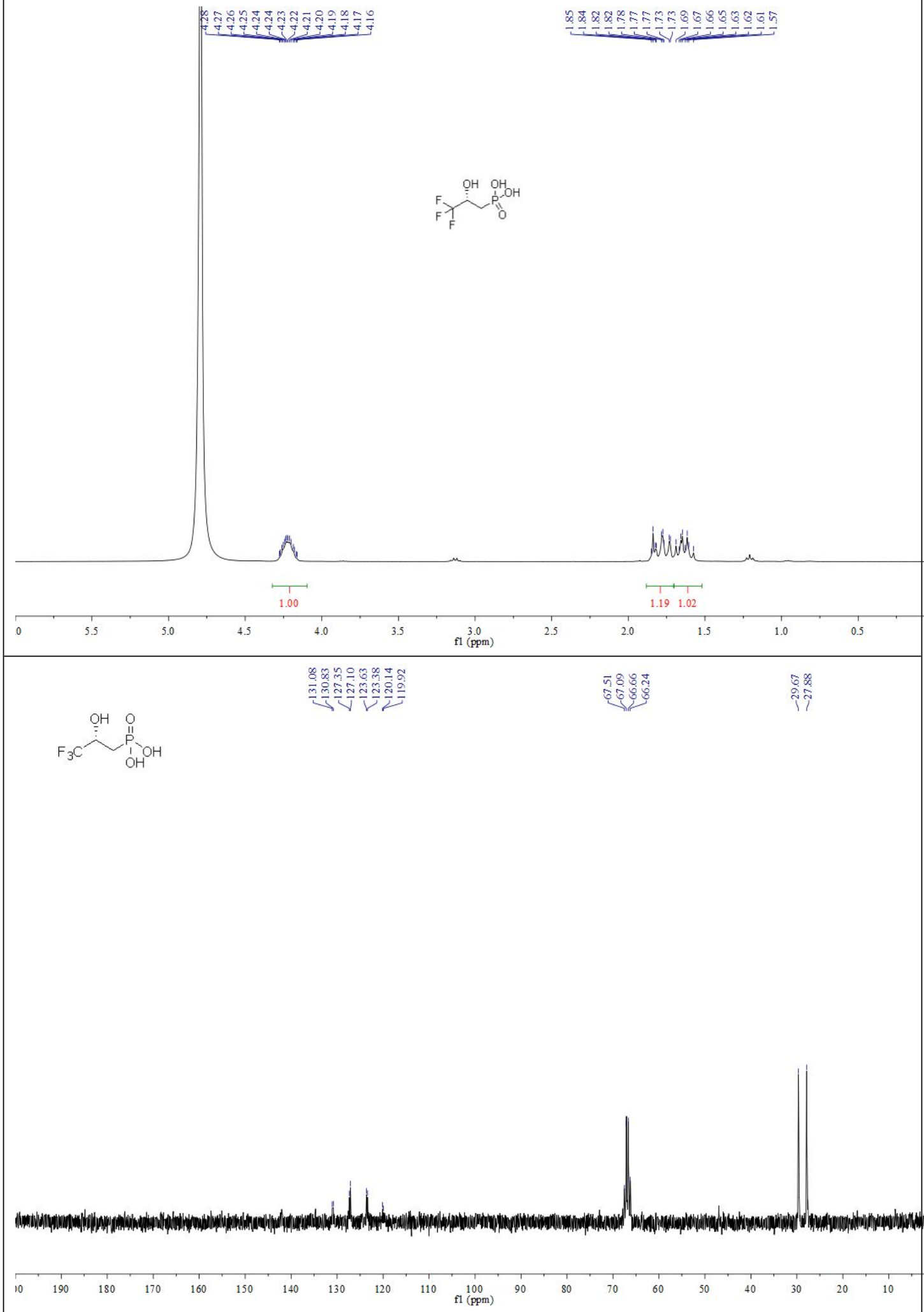


\section{$(1 S, 2 S)$-1,2-epoxy-3,3,3-trifluoropropylphosphonate (3c)}

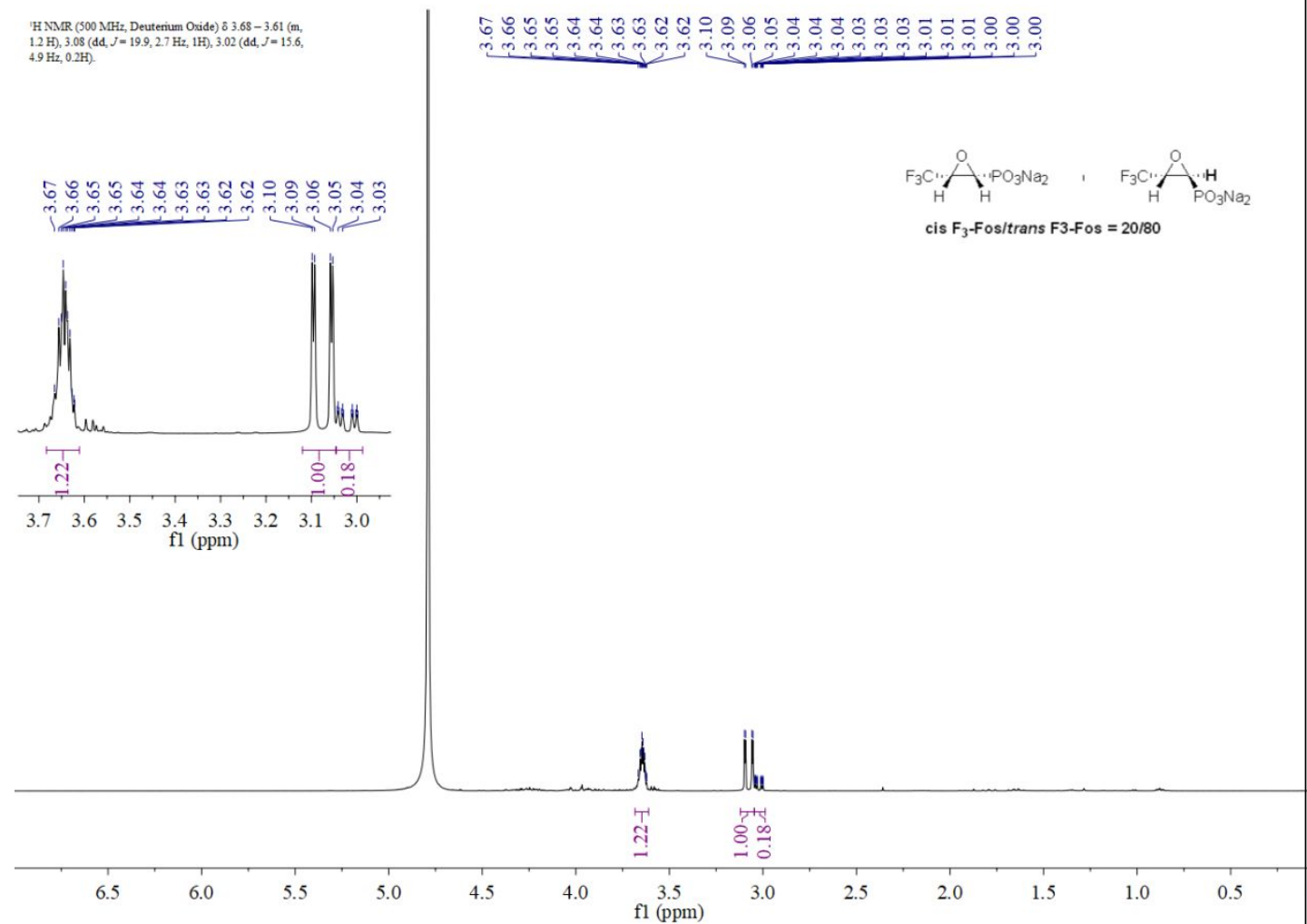

๓ะ์

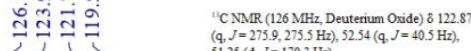

fl (ppm)

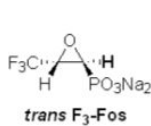

ถึ่

trans $\mathrm{F}_{3}$-Fos
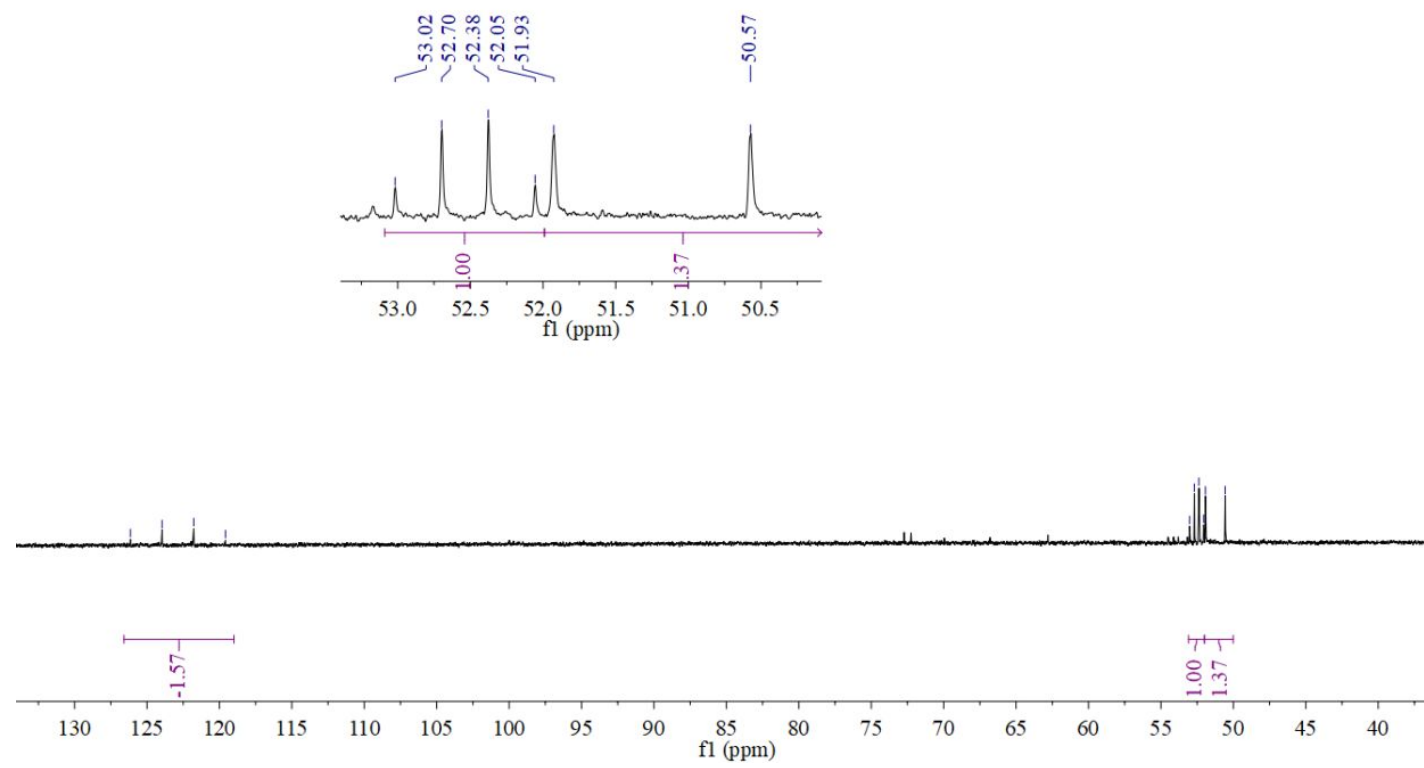


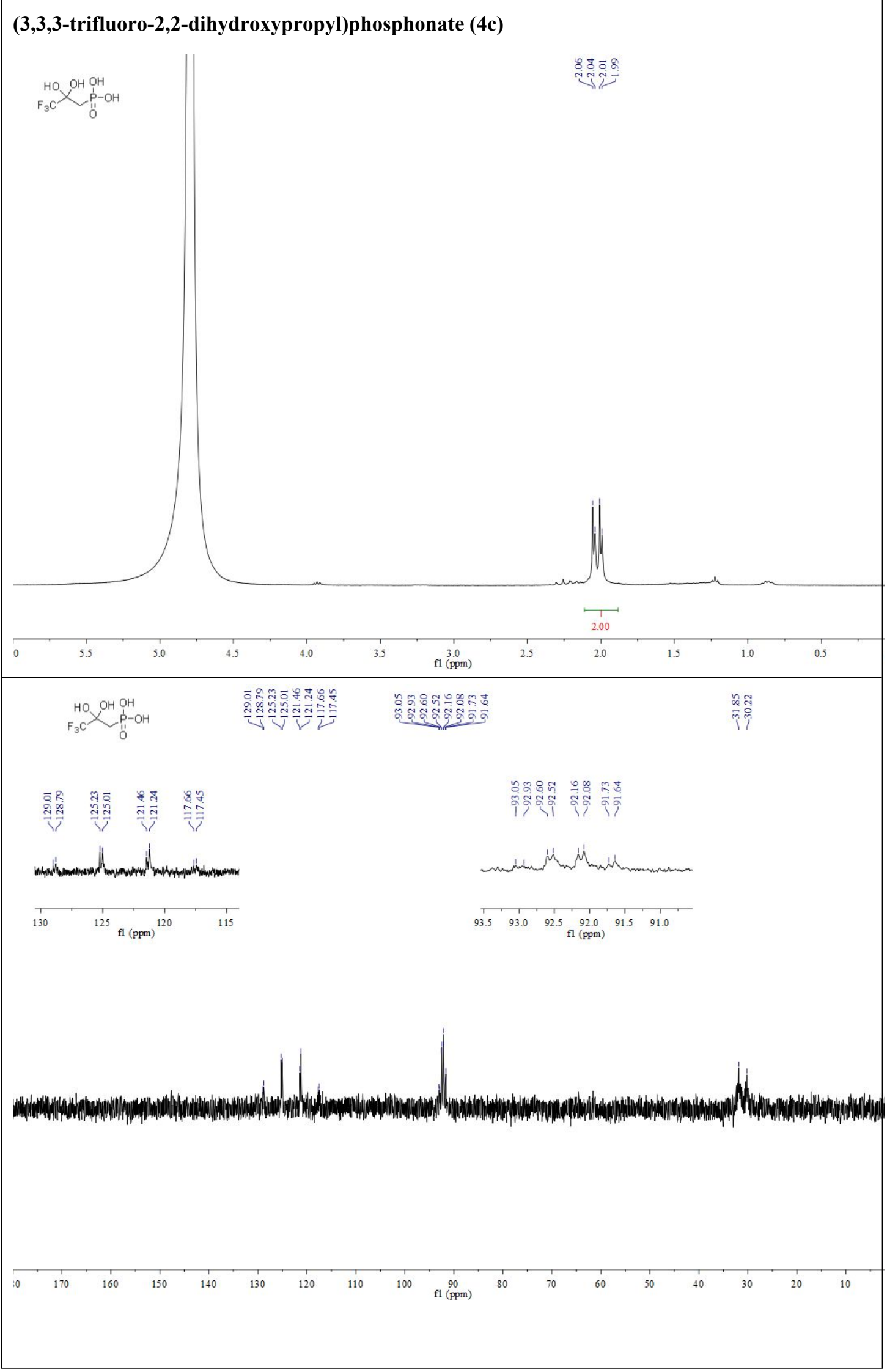




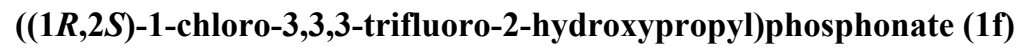
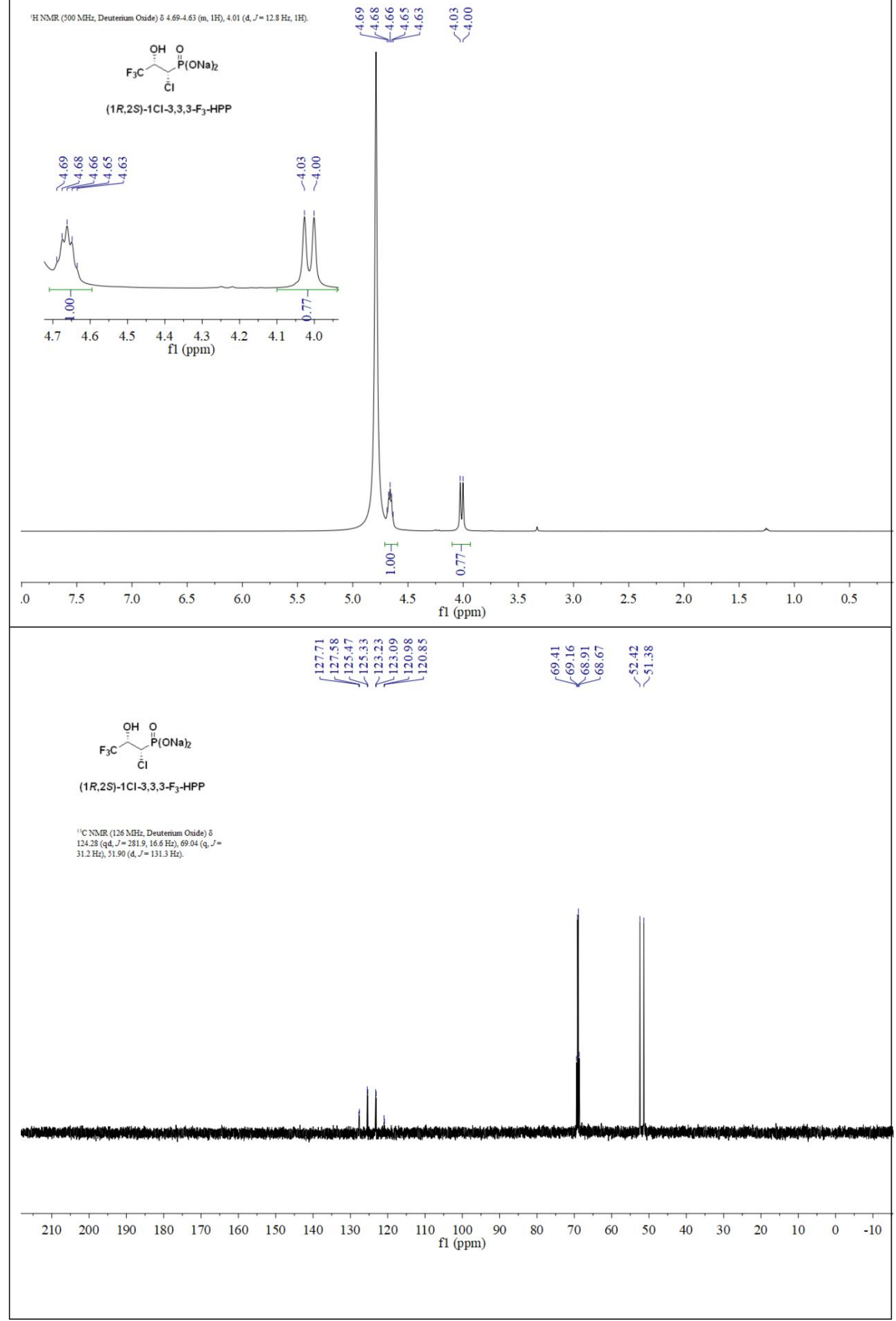


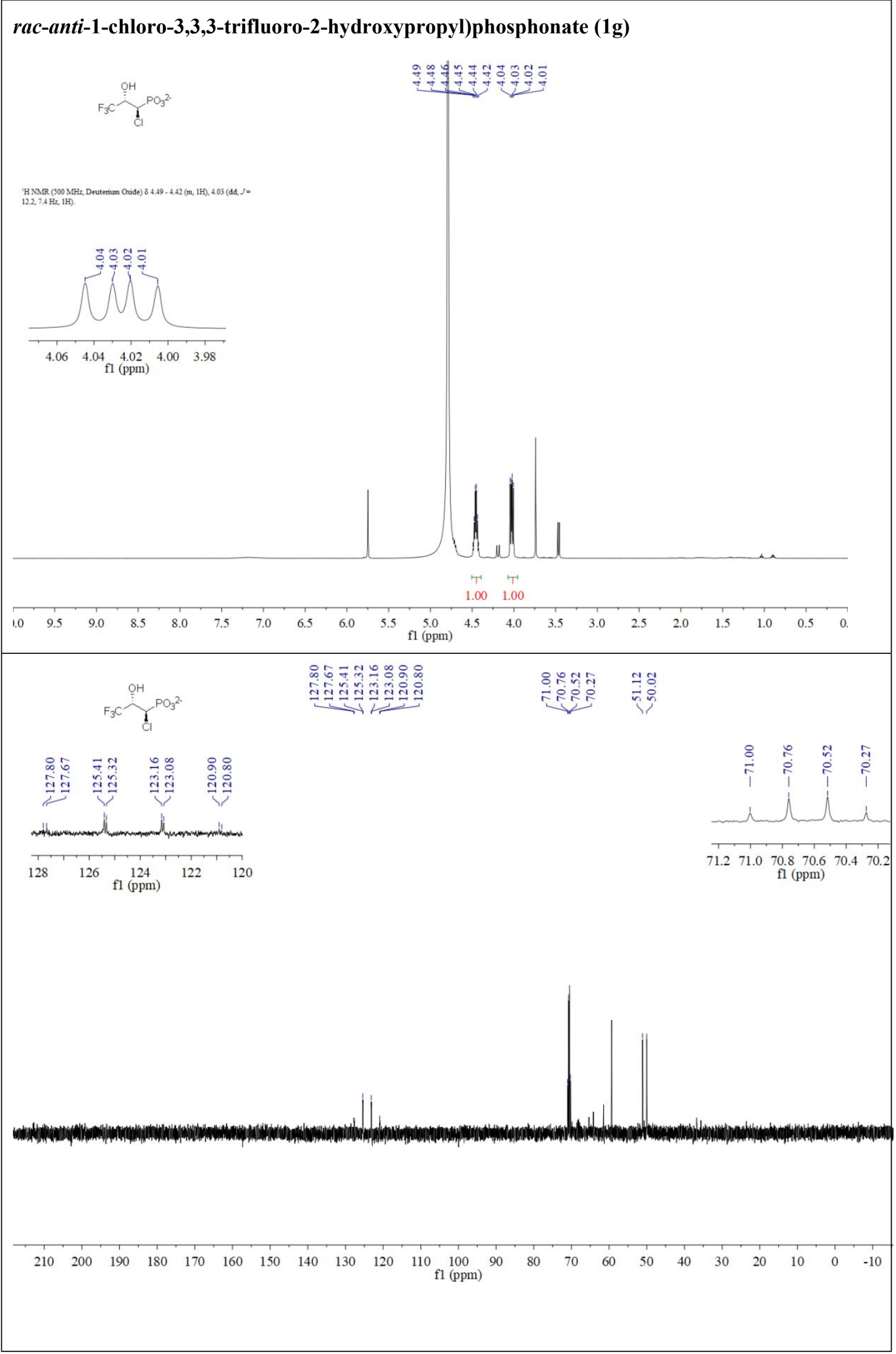




\section{Cis- and trans-3,3,3-F $\mathbf{F}_{3}-\mathrm{Fos}(2 \mathrm{c}$ and $3 \mathrm{c})$}
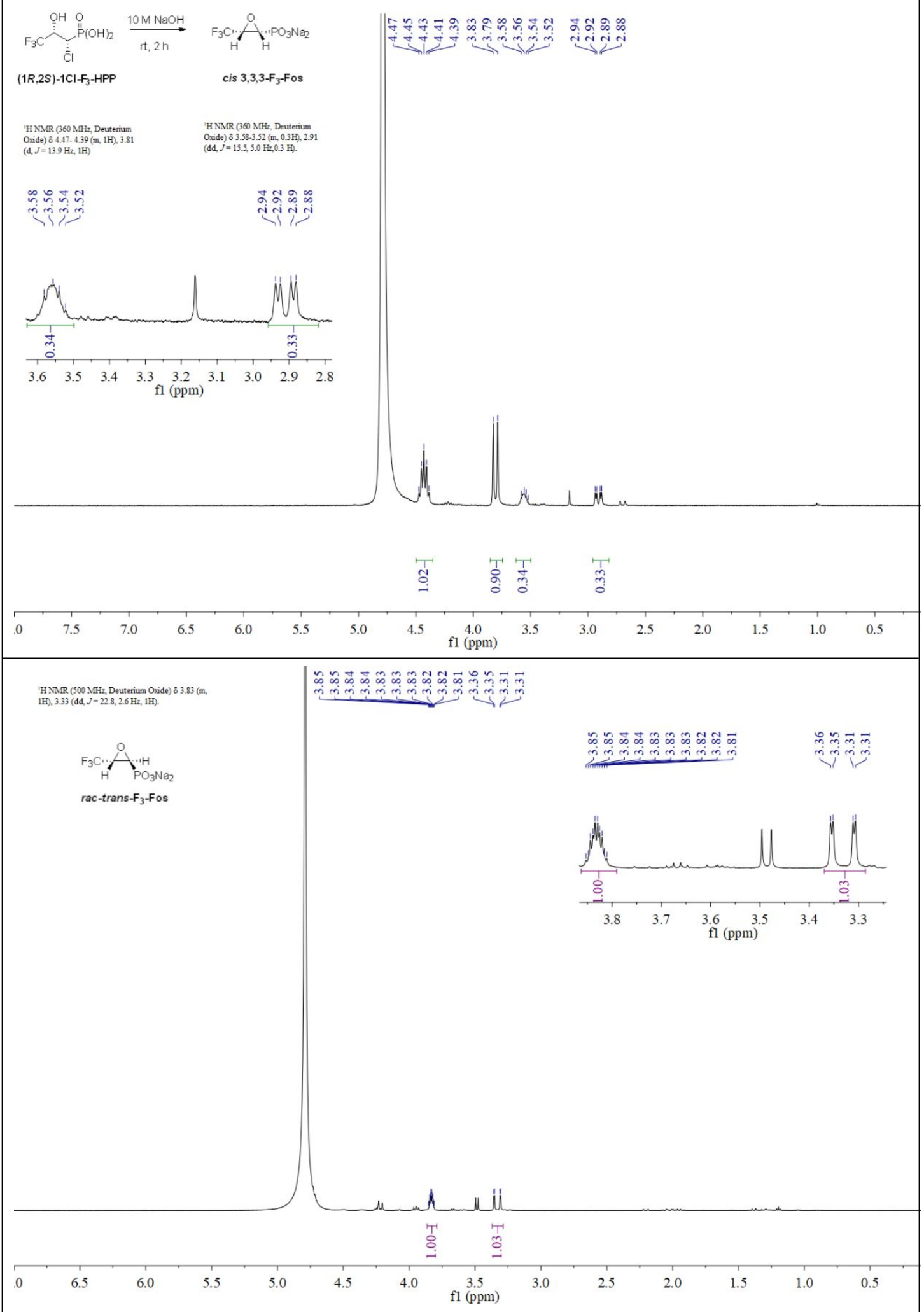
((1R,2S)-1-fluoro-2-hydroxypropyl)phosphonate (1h)

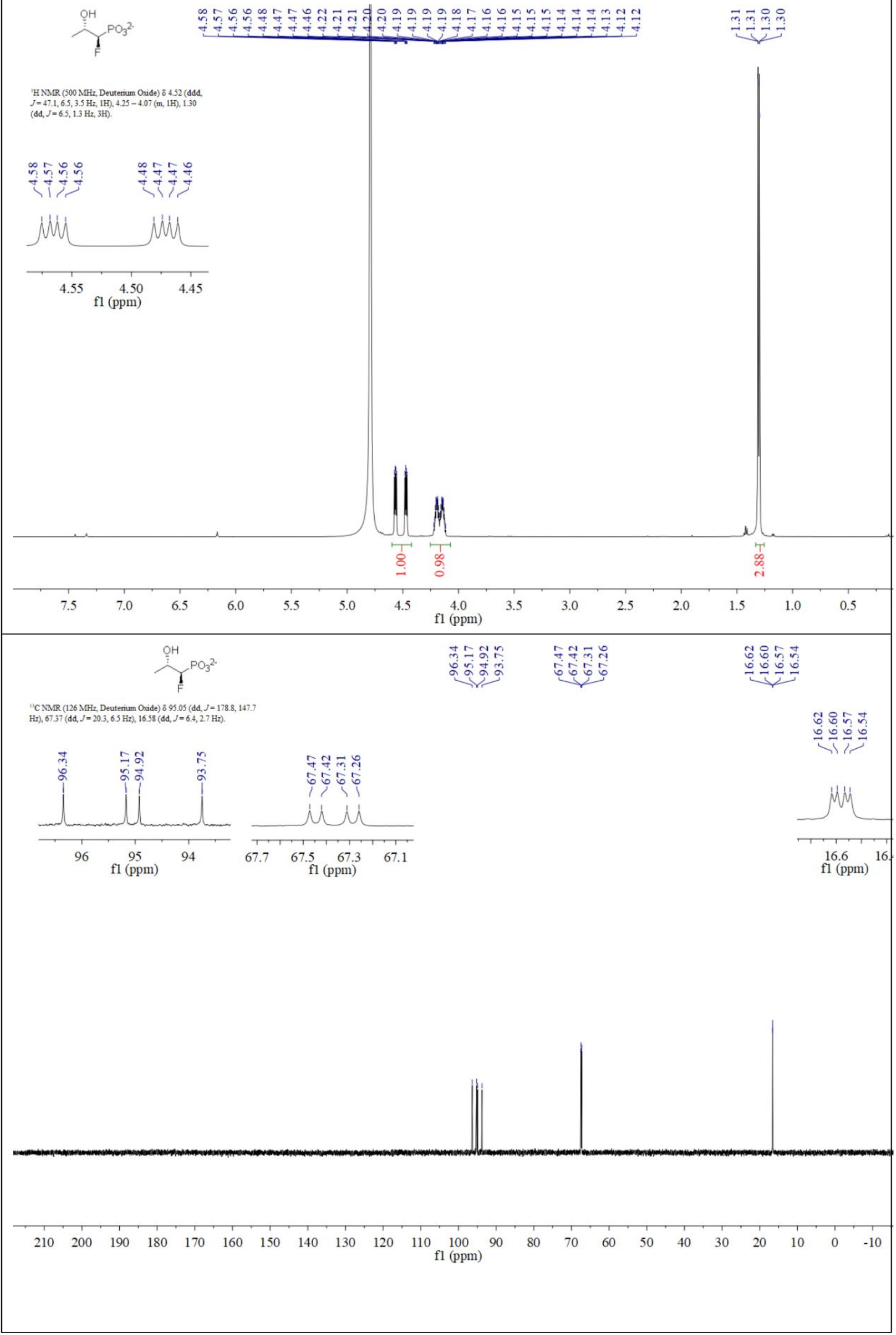




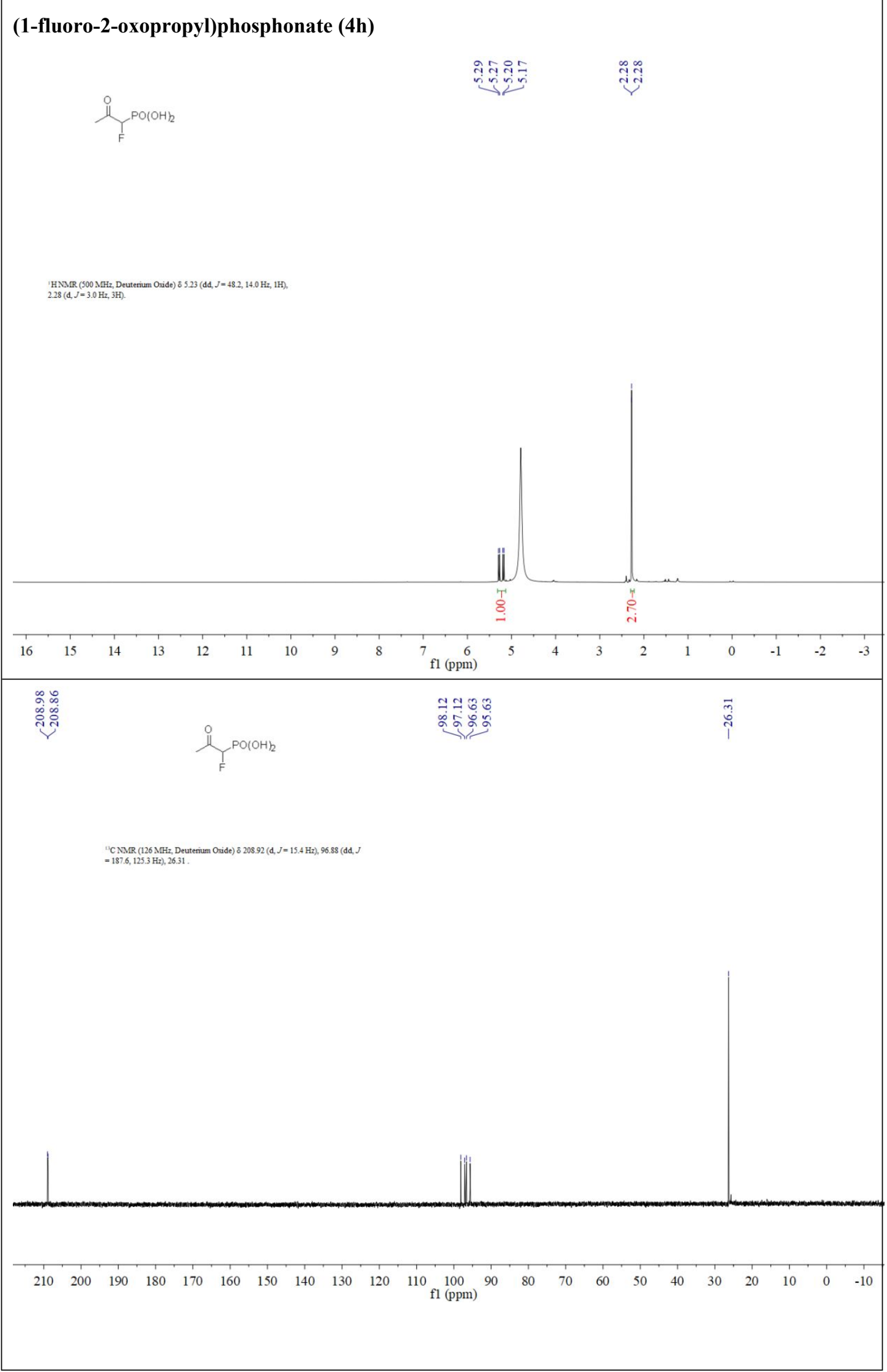




\section{HRMS analysis of $1 \mathrm{~h}$}

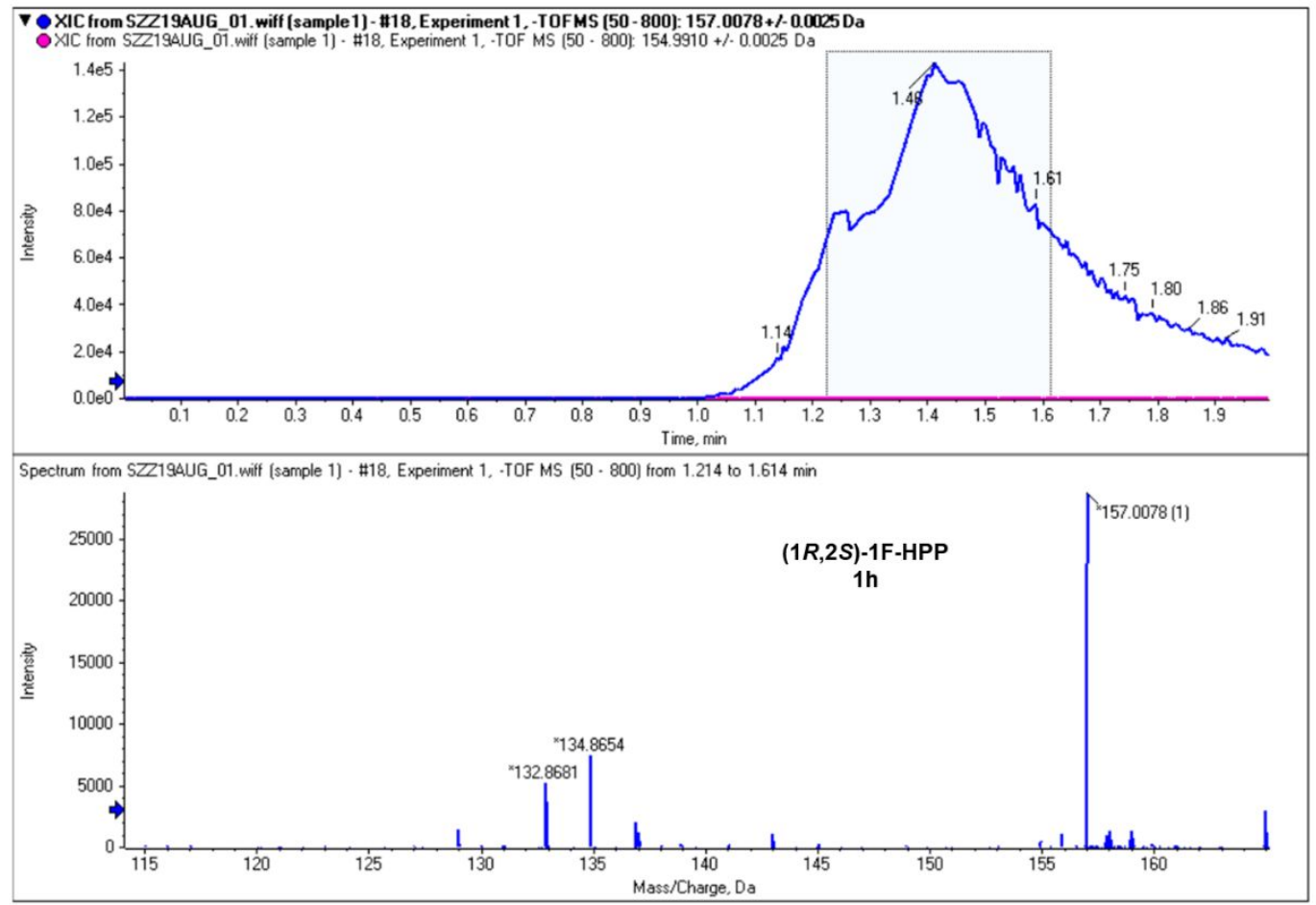

\section{HRMS analysis of $\mathbf{2 h}$}

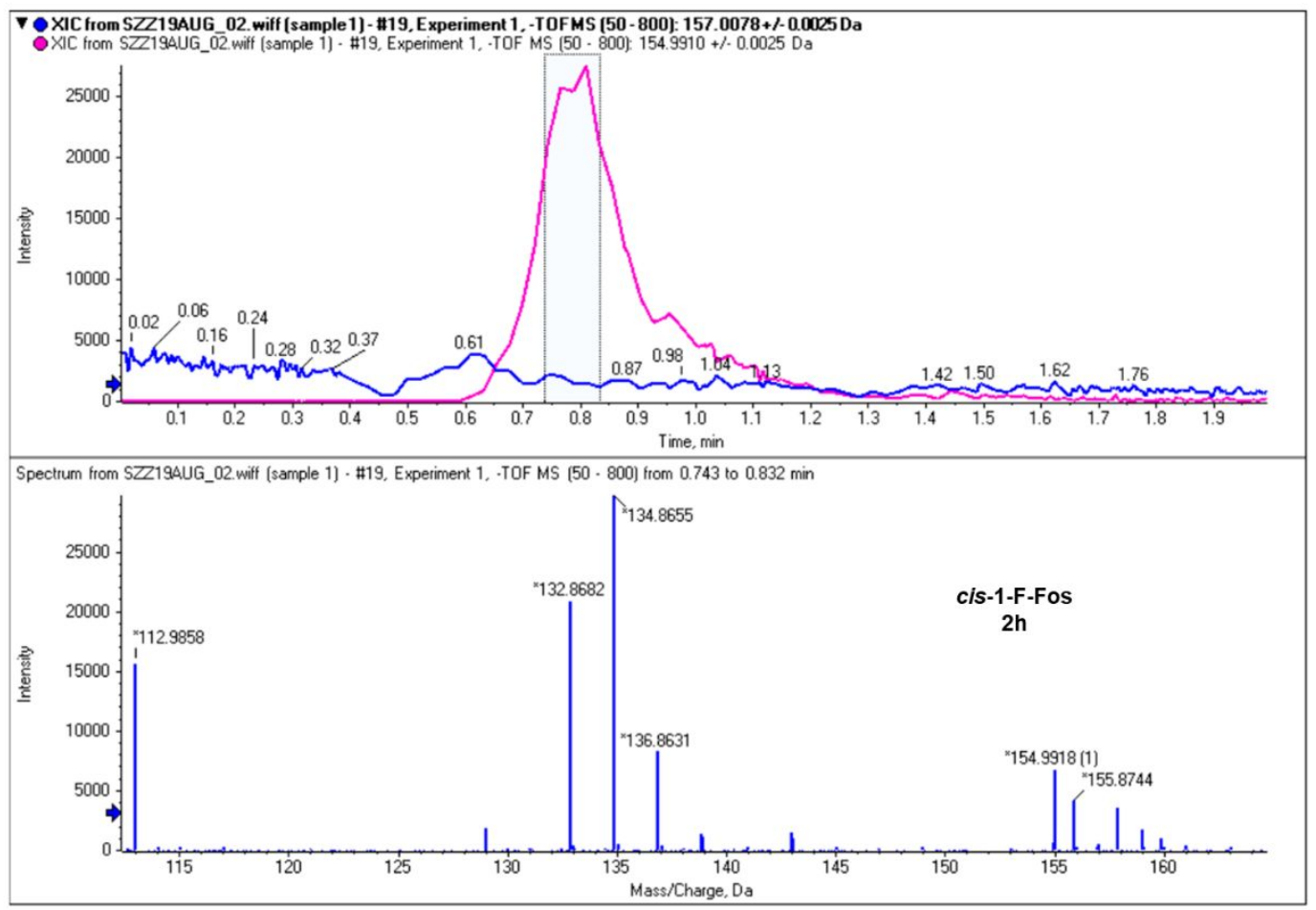




\section{HRMS analysis of $3 \mathrm{~h}$}

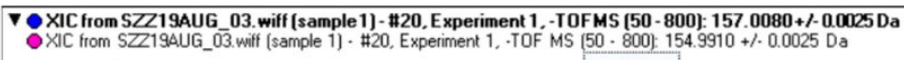

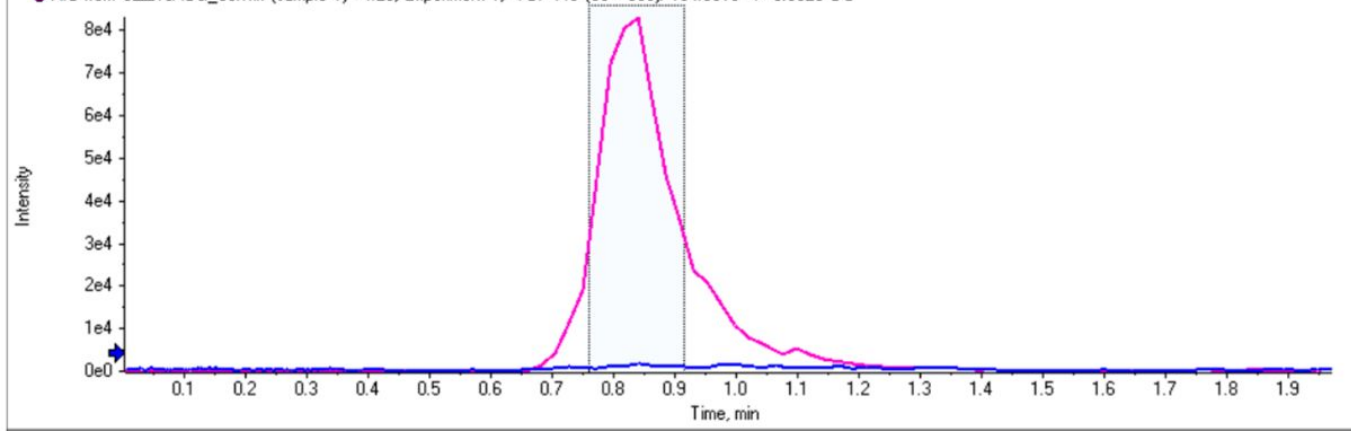

Spectrum from SZZ19AUG_03.wiff (sample 1) - \#20, Experiment 1, -TOF MS $(50 \cdot 800)$ from 0.750 to $0.908 \mathrm{~min}$

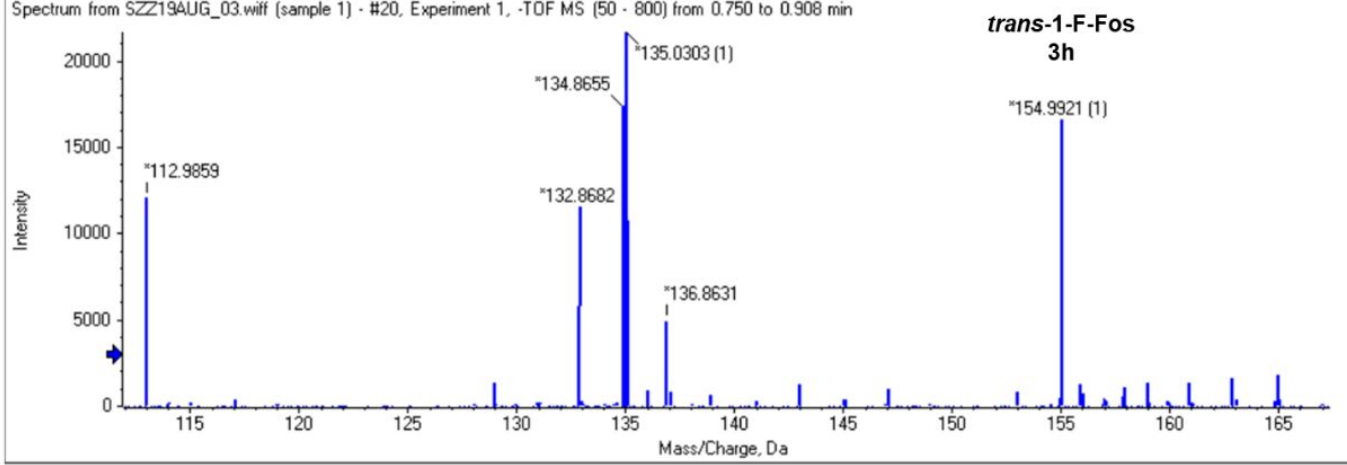

\section{HRMS analysis of $4 \mathrm{~h}$}

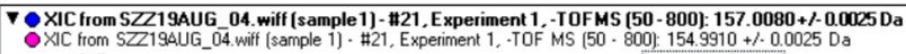

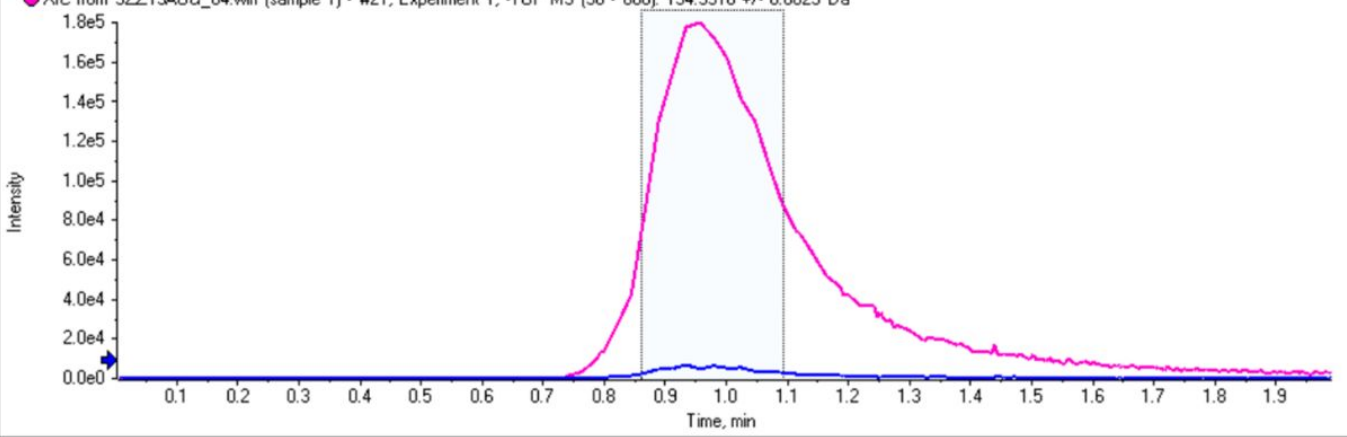

Spectrum from SZZ19AUG_04. wiff (sample 1) · \#21, Experiment 1, ·TOF MS $[50$ - 800) from 0.866 to $1.092 \mathrm{~min}$

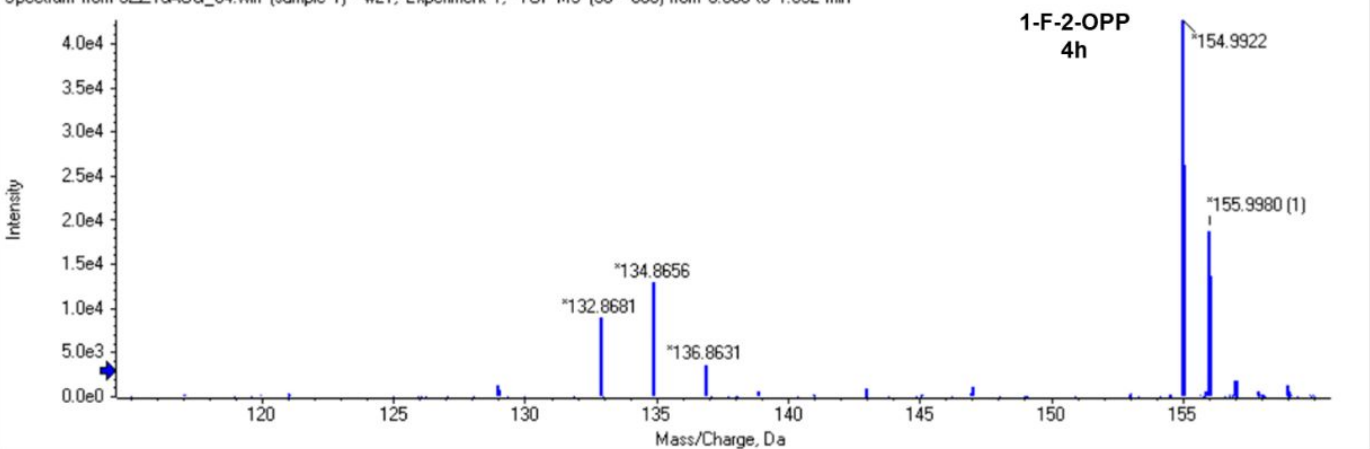




\section{References}

1. Liu, P. H.; Murakami, K.; Seki, T.; He, X. M.; Yeung, S. M.; Kuzuyama, T.; Seto, H.; Liu, H. W., Protein purification and function assignment of the epoxidase catalyzing the formation of fosfomycin. $J$. Am. Chem. Soc. 2001, 123 (19), 4619-4620.

2. Wang, X. Y.; Shi, H. C.; Sun, C.; Zhang, Z. G., Asymmetric epoxidation of cis-1propenylphosphonic acid (CPPA) catalyzed by chiral tungsten(VI) and molybdenum(VI) complexes. Tetrahedron 2004, 60 (48), 10993-10998.

3. Wang, C.; Chang, W. C.; Guo, Y. S.; Huang, H.; Peck, S. C.; Pandelia, M. E.; Lin, G. M.; Liu, H. W.; Krebs, C.; Bollinger, J. M., Jr., Evidence that the fosfomycin-producing epoxidase, HppE, Is a nonheme-iron peroxidase. Science 2013, 342 (6161), 991-995.

4. Marocco, C. P.; Davis, E. V.; Finnell, J. E.; Nguyen, P. H.; Mateer, S. C.; Ghiviriga, I.; Padgett, C. W.; Feske, B. D., Asymmetric synthesis of (-)-fosfomycin and its trans-(1S,2S)-diastereomer using a biocatalytic reduction as the key step. Tetrahedron:Asymmetry 2011, 22 (18-19), 1784-1789.

5. Christensen, B. G.; Leanza, W. J.; Beattie, T. R.; Patchett, A. A.; Arison, B. H.; Ormond, R. E.; Kuehl, F. A., Jr.; Albers-Schonberg, G.; Jardetzky, O., Phosphonomycin: structure and synthesis. Science 1969, 166 (3901), 123-5.

6. Hu, S. J.; Jayaraman, S.; Oehlschlager, A. C., Diastereo- and enantioselective synthesis of synalpha-vinylchlorohydrins and cis-vinylepoxides. J. Org. Chem. 1996, 61 (21), 7513-7520.

7. Sasaki, H.; Irie, R.; Hamada, T.; Suzuki, K.; Katsuki, T., Rational Design of Mn-Salen Catalyst (2) - Highly Enantioselective Epoxidation of Conjugated Cis-Olefins. Tetrahedron 1994, 50 (41), 11827 11838.

8. Hemsley, A.; Arnheim, N.; Toney, M. D.; Cortopassi, G.; Galas, D. J., A Simple Method for SiteDirected Mutagenesis Using the Polymerase Chain-Reaction. Nucleic Acids Res. 1989, 17 (16), $6545-$ 6551.

9. Hendlin, D.; Stapley, E. O.; Jackson, M.; Wallick, H.; Miller, A. K.; Wolf, F. J.; Miller, T. W.; Chaiet, L.; Kahan, F. M.; Foltz, E. L.; Woodruff, H. B., Phosphonomycin, a New Antibiotic Produced by Strains of Streptomyces. Science 1969, 166 (3901), 122-\&.

10. McLuskey, K.; Cameron, S.; Hammerschmidt, F.; Hunter, W. N., Structure and reactivity of hydroxypropylphosphonic acid epoxidase in fosfomycin biosynthesis by a cation- and flavin-dependent mechanism. Proc. Natl. Acad. Sci. U. S. A. 2005, 102 (40), 14221-14226.

11. Woschek, A.; Wuggenig, F.; Peti, W.; Hammerschmidt, F., On the transformation of $(S)-2-$ hydroxypropyl-phosphonic acid into fosfomycin in Streptomyces fradiae: a unique method of epoxide ring formation. ChemBioChem 2002, 3 (9), 829-835.

12. Wang, B.; Blaszczyk, A. J.; Knox, H. L.; Zhou, S.; Blaesi, E. J.; Krebs, C.; Wang, R. X.; Booker, S. J., Stereochemical and Mechanistic Investigation of the Reaction Catalyzed by Fom3 from Streptomyces fradiae, a Cobalamin-Dependent Radical S-Adenosylmethionine Methylase. Biochemistry 2018, 57 (33), 4972-4984.

13. Munos, J. W.; Moon, S. J.; Mansoorabadi, S. O.; Chang, W. C.; Hong, L.; Yan, F.; Liu, A. M.; Liu, H. W., Purification and characterization of the epoxidase catalyzing the formation of fosfomycin from Pseudomonas syringae. Biochemistry 2008, 47 (33), 8726-8735.

14. ZymanczykDuda, E.; Skwarczynski, M.; Lejczak, B.; Kafarski, P., Accurate assay of enantiopurity of 1-hydroxy- and 2-hydroxyalkylphosphonate esters. Tetrahedron:Asymmetry 1996, 7 (5), 1277-1280. 15. Skwarczynski, M.; Lejczak, B.; Kafarski, P., Enantioselective hydrolysis of 1butyryloxyalkylphosphonates by lipolytic microorganisms: Pseudomonas fluorescens and Penicillium 
citrinum. Chirality 1999, 11 (2), 109-114.

16. Yuan, C. Y.; Li, J. F.; Zhang, W. C., Studies on organophosphorus compounds 135 - A facial chemoenzymatic method for the preparation of chiral 1,2-dihydroxy-3,3,3,trifluoropropanephosphonates. J. Fluorine Chem. 2006, 127 (1), 44-47.

17. Sterk, D.; Stephan, M.; Mohar, B., Highly enantioselective transfer hydrogenation of fluoroalkyl ketones. Org. Lett. 2006, 8 (26), 5935-5938.

18. Kitamura, M.; Tokunaga, M.; Noyori, R., Asymmetric Hydrogenation of Beta-Keto Phosphonates - a Practical Way to Fosfomycin. J. Am. Chem. Soc. 1995, 117 (10), 2931-2932.

19. Rudzinska, E.; Berlicki, L.; Mucha, A.; Kafarski, P., Chiral discrimination of ethyl and phenyl Nbenzyloxycarbonylaminophosphonates by cyclodextrins. Tetrahedron:Asymmetry 2007, 18 (13), 15791584 .

20. Rao, R. N.; Santhakumar, K., Cyclodextrin assisted enantiomeric recognition of emtricitabine by F-19 NMR spectroscopy. New J. Chem. 2016, 40 (10), 8408-8417.

21. Bongini, A.; Camerini, R.; Panunzio, M., Efficient synthesis of the four diastereomers of phosphothreonine from lactaldehyde. Tetrahedron:Asymmetry 1996, 7 (5), 1467-1476.

22. Radwan-Olszewska, K.; Palacios, F.; Kafarski, P., Selective Synthesis of alpha-Fluoro-beta-ketoand alpha-Fluoro-beta-aminophosphonates via Electrophilic Fluorination by Selectfluor. J. Org. Chem. 2011, 76 (4), 1170-1173.

23. Singh, U. S.; Mulamoottil, V. A.; Chu, C. K., Synthesis of an Anti-hepatitis B Agent, 2'-Fluoro-6'methylene-carbocyclic Adenosine (FMCA) and Its Phosphoramidate (FMCAP). J. Org. Chem. 2019, 84 (2), 752-759. 